\title{
State-Of-The-Art Hydrogen Sulfide Control For Geothermal Energy Systems: 1979
}

March 1980

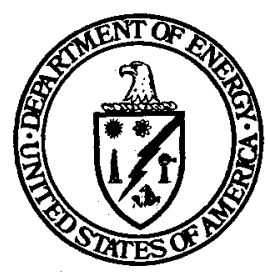

Prepared by:

Frederick B. Stephens

John H. Hill and Paul L. Phelps, Jr.

Mr. Douglas W. Boehm, DOE Project Manager

Prepared for:

U.S. Department of Energy Assistant Secretary for Environment Office of Environmental Compliance and Overview Unvironmental Control Technology Division Washington, D.C. 20545 


\section{DISCLAIMER}

This report was prepared as an account of work sponsored by an agency of the United States Government. Neither the United States Government nor any agency Thereof, nor any of their employees, makes any warranty, express or implied, or assumes any legal liability or responsibility for the accuracy, completeness, or usefulness of any information, apparatus, product, or process disclosed, or represents that its use would not infringe privately owned rights. Reference herein to any specific commercial product, process, or service by trade name, trademark, manufacturer, or otherwise does not necessarily constitute or imply its endorsement, recommendation, or favoring by the United States Government or any agency thereof. The views and opinions of authors expressed herein do not necessarily state or reflect those of the United States Government or any agency thereof. 


\section{DISCLAIMER}

Portions of this document may be illegible in electronic image products. Images are produced from the best available original document. 
Technical Report Documentation Page

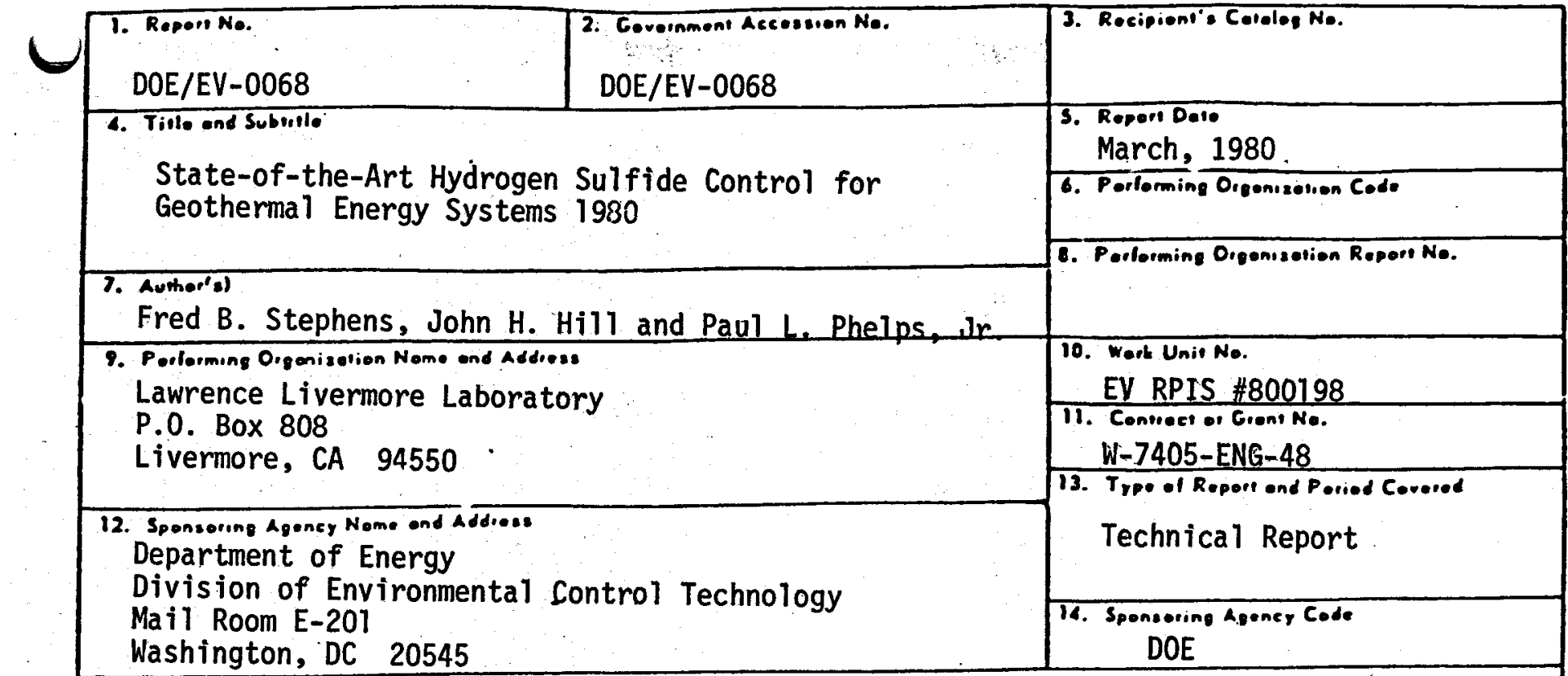

15. Supplomeniary Noles

Division of Environmental Control Technology, U.S. Department of Energy

16. Abortest

Present efforts by the geothermal industry are directed toward developing economically viable hydrogen sulfide emission control technologies having efficiencies that satisfy federal and state emission requirements. This report discusses existing state-of-the-art technologies for removal of hydrogen sulfide along with a comparative assessment of their efficiencies, reliabilities and costs. Other related topics include the characteristics of vapor-dominated and liquid-dominated resources, energy conversion systems, and the sources of hydrogen sulfide emissions.

The report indicates that upstream control technologies are preferred over downstream technologies primarily because upstream removal of hydrogen sulfide inherently controls all downstream emissions including steam-stacking. Two upstream processes for vapor-dominated resources appear promising; the copper sulfate (EIC) process, and the steam converter (Coury) process combined with an off-gas abatement system such as a Stretford unit. For liquid-dominated systems that produce steam, the process where the non-condensible gases are scrubbed with spent geothermal fluid appears to be promising. An efficient downstream technology is the Stretford process for non-condensible gas removal. In this case, partitioning in the surface condenser will determine the overall abatement efficiency.

Recommendations for future environmental control technology programs include a) studies addressing $\mathrm{H}_{2} \mathrm{~S}$ emissions associated with steam stacking, b) examining the use of the Stretford process upstream, c) continuing studies of the steam converter (Coury) process, d) determining the feasibility of electrolytic processes for hydrogen: sulfide removal and, e) a follow-up program of the DOE sponsored ASCOT study.

17. Koy word:

Hydrogen sulfide, geothermal emissions air quality, enyironment
18. Discibulion sieiomont This document is available under catalog number DOE/EV-0068 from National Technical Information Service, U.S. Department of Commerce, 5285 Port Royal Road, Springfield, Virginia 22161

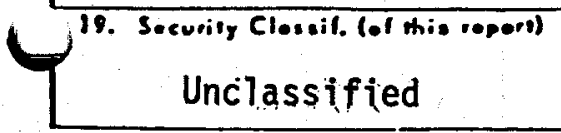

D. Socuriey Clorsil. (ol this pege)
N/A




\section{CONTENTS}

Abstract. ........................ iv

Executive Sumary ....................... v

List of figures ....................... vii

List of Tables......................... ix

I. Introduction $\ldots \ldots \ldots \ldots \ldots \ldots$

Background. . . . . . . . . ....... 1

Best Available Control Technology ............. 2

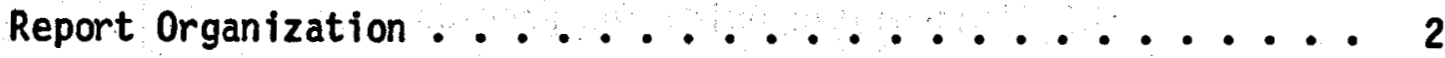

II. Resource Characterization ................. 3

Variability of Resources................ 3

III. Energy Conversion Technologies and Plant Design ......... 6

Conversion Technologies .............. 6

Direct-Steam Power Generation .............. 6

Flashed-Steam Power Generation. ............ 8

Flashed Binary Cycle. ................ 9

Total-Flow Power Generation .................. 11

Geothermal Utilization for Electric Power .......... 12

Geothermal Utilization for Nonelectric Power......... 14

IV. Hydrogen Sulfide Emission Sources , ............... 15

Hydrogen Sulfide Release Points .............. 16

A Vapor-Dominated Plant - The Geysers .......... 16

A Liquid-Dominated Flashed-Steam Plant. .......... 21

Liquid-Dominated Binary Plants. . . . . . . . . . . 24

Steam Stacking. . . . . . . . . . . . . 24

V. Hydrogen Sulfide Control Requirements ............ 25

Measurements of Ambient $\mathrm{H}_{2} \mathrm{~S}$ Concentrations. ....... 26

Modeling. .................... 28

Regulatory Control Aspects. ............. 33

Technical Control Aspects ................. 38 


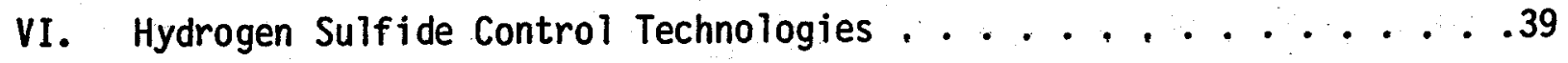

Hydrogen Sulfide Abatement During Well Drilling

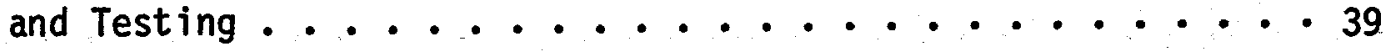

Upstream Abatement Technology for Power Plant Emissions . . . 43

The EIC Copper Sulfate Process .......... 46

Solid Sorbents............... 51

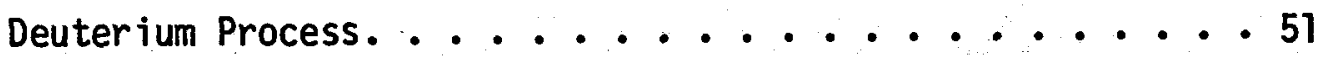

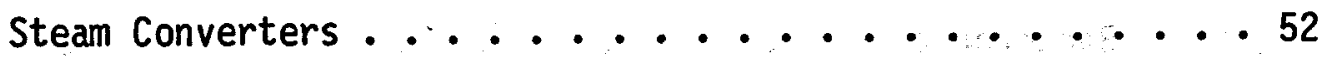

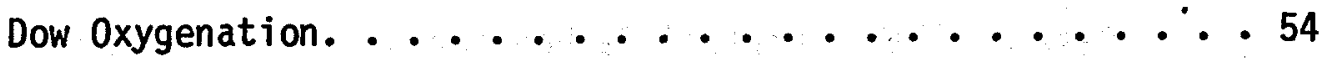

SRI Electrolytic 0xidation Process ........ 55

Downstream Abatement Technology for Power Plant Emissions . . 56

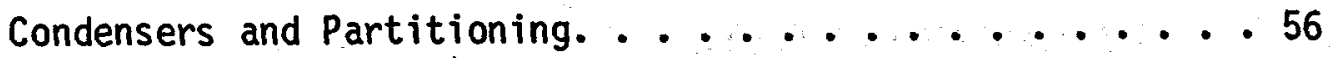

The Stretford Process............. 60

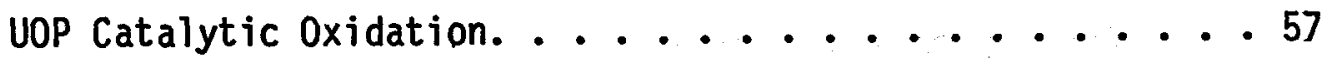

Jefferson Lake Process .............. 63

Burner-Scrubber Process. ............63

Ferrox Process ..................... 64

Caustic Soda Process .............. 65

Sodium Hypochlorite Process. . . . . . . . . . 65

Potassium Permanganate Process ........... 66

Iron Catalyst Process. . . . . . ..... 66

Hydrogen Peroxide Process. . . . . . . . . 68

0zone. . . . . . . . . . ..... 68

Wackenroder Reaction ................. 69

Brine Scrubbing Process............. 69

Benfield Process .................. 70

VII. Analysis and Assessment of Abatement Systems . . . . . . . 71

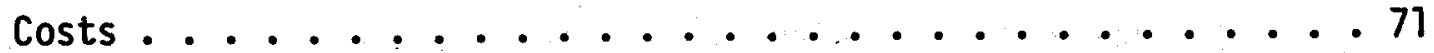

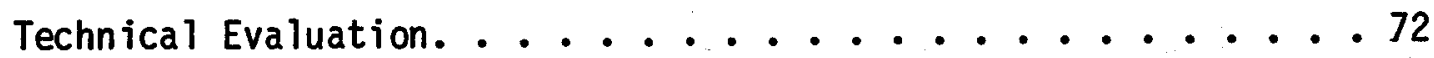

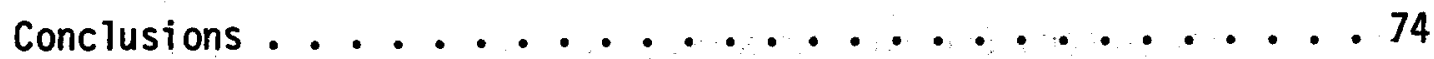

VIII. Recomendations of Future Environmental Control Technology. . . . 75

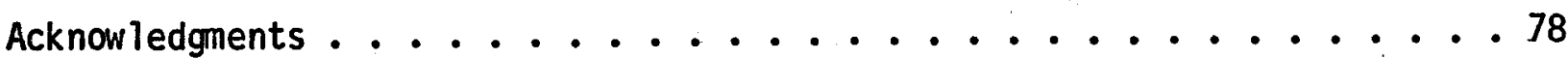

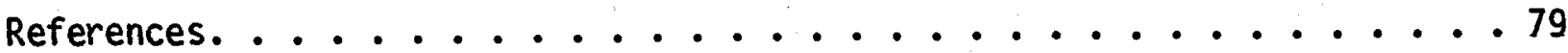


Appendix A - Methodology Used for Calculaton of Vapor-Liquid Equilibrium Distribution of Noncondensable Gases $-\mathrm{H}_{2} \mathrm{~S}, \mathrm{NH}_{3}$, and $\mathrm{CO}_{2}, \ldots \mathrm{A}-\mathrm{l}$

Appendix B - Cost Data _..................... B-1

Appendix C - Definition of a Class I and Class II-1 Disposal Site. . . . C-I

Appendix $\mathrm{D}$ - Proposed state of California Regulations for $\mathrm{H}_{2} \mathrm{~S}$

Abátement at The Geysers. ............. 
ABSTRACT

This report has been prepared for the Environmental Control Technology Division, Office of Environmental Compliance and Overview, Assistant Secretary for Environment, of the Department of Energy (DOE).

Present efforts by the geothermal industry are directed toward developing economically viable hydrogen sulfide $\left(\mathrm{H}_{2} \mathrm{~S}\right)$ emission control technologies having efficiencies that satisfy federal and state emission requirements. This report discusses existing state-of-the-art technologies for removal of $\mathrm{H}_{2} \mathrm{~S}$ along with a comparative assessment of their efficiencies, reliabilities and costs. Other related topics include the characteristics of vapor-dominated and liquid-dominated resources, energy conversion systems, and the sources of $\mathrm{H}_{2} \mathrm{~S}$ emissions.

The report indicates that upstream control technologies are preferred over downstream technologies primarily because upstream removal of $\mathrm{H}_{2} \mathrm{~S}$ inherently controls all downstream emissions including steam-stacking. Two upstream processes for vapor-dominated resources appear promising; the copper sulfate (EIC) process, and the steam converter (Coury) process combined with an off-gas abatement system such as a Stretford unit. For liquid-dominated systems that produce steam, a process where the non-condensible gases are scrubbed with spent geothermal fluid appears to be promising. An efficient downstream technology is the Stretford process for $\mathrm{H}_{2} \mathrm{~S}$ removal from the non-condensible gas stream. In this case, partitioning in the turbine surface condenser will determine the overall abatement efficiency.

Recommendations for future environmental control technology programs include a) studies addressing $\mathrm{H}_{2} \mathrm{~S}$ emissions associated with steam stacking, b) examining, the use of the Stretford process upstream, c) continuing studies of the steam converter (Coury) process, d) determining the feasibility of electrolytic processes for $\mathrm{H}_{2} \mathrm{~S}$ removal and, e) a follow-up program of the DOE sponsored Atmospheric Studies in Complex Terrain (ASCOT) study.

Reference to a company or product name does not imply approval or recommendation of the product by the University of California or the U.S. Department of Energy to the exclusion of others that may be suitable. 


\section{EXECUTIVE SUMMARY}

The report provides a revfew of the state of the art hydrogen sulfide $\left(\mathrm{H}_{2} \mathrm{~S}\right)$ control technologies presently applicable to geothermal energy sources, and identifies the most promising $\mathrm{H}_{2} \mathrm{~S}$ removal processes for future geothermal applications. Processes for $\mathrm{H}_{2} \mathrm{~S}$ abatement in both vapordominated systems and liquid-dominated systems are included.

Vapor-dominated systems, also known as dry-steam systems, are those where steam produced in underground resources is recovered at slightly superheated conditions. In these systems, the major component is steam containing $\mathrm{CO}_{2}$, $\mathrm{H}_{2} \mathrm{~S}$, and other gases. Liquid-dominated systems are primarily made up of hot water containing dissolved solids as well as dissolved gases. When these resources are utilized for the generation of electric power, $\mathrm{H}_{2} \mathrm{~S}$ is released into the atmosphere and to various waste streams.

There are several release points of the $\mathrm{H}_{2} \mathrm{~S}$ emissions which include:

- Well--drilling emissions, standby venting, and bypass venting

- Fluid transmission--instrument vents, cyclone vents, and temperature equaljzer vents

Power plant (conversion process) emissions.

There are two main approaches for removing $\mathrm{H}_{2} \mathrm{~S}$. These are upstream abatement (ahead of the turbine), and downstream abatement. Since there have been no comercially available upstream abatement processes successfully applied to geothermal uses, most of the technology presently used is directed toward downstream $\mathrm{H}_{2} \mathrm{~S}$ abatement methods. The downstream processes have been applied to the noncondensable off-gas stream and to the $\mathrm{H}_{2} \mathrm{~S}$ dissolved in the condensate/cooling-tower water.

The Stretford process has recently been applied to the noncondensable gas at The Geysers on Unit 15 with an abatement efficiency exceeding $99 \%$. However, on 1 y $75-80 \%$ of the $\mathrm{H}_{2} \mathrm{~S}$ is partitioned into the noncondensable gas stream by the surface condensers on Unit 15. Therefore, overall abatement is limited to 75-80\%. Recent experiments, however, indicate possible improvement to $90 \%$ overall abatement. The stretford process involves scrubbing the $\mathrm{H}_{2} \mathrm{~S}$-containing gas with an aqueous solution containing sodium carbonate, sodium metavanadate, and anthraquinone disulfonic acid (ADA). 
The burner-scrubber process has also been used at The Geysers. In this process the noncondensable gas stream is burned to oxidize $\mathrm{H}_{2} \mathrm{~S}$ to $\mathrm{SO}_{2}$, which is scrubbed out of the gas stream with cooling water. Hork on the process was suspended because only $50 \% \mathrm{H}_{2} \mathrm{~S}$ abatement was achieved, and there were major maintenance problems.

Treatment of the condensate/cooling water using the iron-catalyst system is the main process now used at The Geysers. It has been modified to include the use of hydrogen peroxide for greater efficiency. Sodium hydroxide is used to maintain the $\mathrm{pH}$ of the circulating water between 7.4 and 7.8. Overal1 abatement of about $90 \%$ is now being obtained. However, because of corrosion and the high solids produced, this process causes high operating and maintenance costs, and an apparently reduced plant capacity factor. 1

Upstream abatement technologies are the best candidates for the control of $\mathrm{H}_{2} \mathrm{~S}$ emissions because they will, if successful, solve the steam stacking problem. Three processès appear to be promising: The EIC copper sulfate process, the steam converter with auxillary $\mathrm{H}_{2} \mathrm{~S}$ removal, and the Dow oxygenation process.

Extensive pilot plant tests of the EIC process on Unit 7 at The Geysers have demonstrated $95 \%$ to $98 \%$ removal of $\mathrm{H}_{2} \mathrm{~S}$. This pilot plant processes $100,000 \mathrm{lb}$ of steam. A commercial scale (110 MW) facility will process two million lb/h of geothermal steam. Abatement is achieved by scrubbing the steam with a copper sulfate solution which reacts with the $\mathrm{H}_{2} \mathrm{~S}$ to precipitate copper sulfide. A pressure-leach unit regenerates copper sulfate from the copper sulfide, removing any free sulfur formed. The copper sulfate is then recycled to the scrubbing tower. The EIC process also removes armonia, Joron, and particulates from the steam. The process can be used to remove $\mathrm{H}_{2} \mathrm{~S}$ from steam obtained from vapor-dominated resources or from flashed steam derived from liquid-dominated sources.

The second promising candidate for upstream abatement is the steam converter to separate $\mathrm{H}_{2} \mathrm{~S}$ from steam, coupled with a Stretford unit to treat the $\mathrm{H}_{2} \mathrm{~S}$. A pilot plant steam converter is being tested at the Geysers.

Although the Dow oxygenation process is somewhat costly and presents a potential corrosion problem, it is a candidate for use on liquid geothermal resources. 
Fig. 1. Direct steam process ...................

2. Flashed steam process. ............... 8

3. Flashed binary cycle process ............ 9

4. Binary cycle (hot water) process .......................

5. Total flow process........................... 11

6. Direct heating (closed system) ............. 14

7. Typical flow of steam through an unabated power plant showing the distribution of $\mathrm{H}_{2} \mathrm{~S}, \mathrm{NH}_{3}$ and $\mathrm{B} . \ldots \ldots \ldots . \ldots \ldots 21$

8. Schematic of power plant utilizing a liquiddominated resource to produce flashed steam ....... 23

9. Locations of $\mathrm{H}_{2} \mathrm{~S}$ pollution roses and monitoring stations in the SRI network at The Gysers ......... . 27

10. Average $\mathrm{H}_{2} \mathrm{~S}$ concentrations measured by PG\&E at

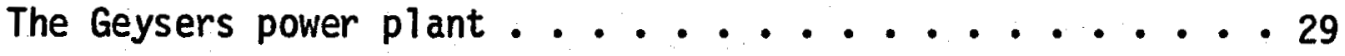

11. Siting pattern for 30 power plant units in the 3000 MW scenario. ..................... 32

12. Isopleth plot of annual average ground level

$\mathrm{H}_{2} \mathrm{~S}$ concentrations in the Imperial Valley ....... 32

13. A typical geothermal drilling/muffler set-up. ....... 41

14. Hydrogen sulfide emissions during drilling. ....... 42

15. A logic diagram to indicate some abatement

technologies for geothermal steam plants and where they may be applied. . . . . ....... 44

16. A logic diagram to indicate some abatement technologies

for liquid geothermal resources. . . . . . . 45

17. Simplified schematic of the EIC copper sulfate process. . . 47

18. Photo of the EIC scrubbing tower on the pilot plant

at PG\&E's Unit 7, The Geysers........... 49

19. Photo of the EIC copper sulfate regenerating unit

and scrubbing tower on PG\&E's Unit 7, The Geysers. .... 50 
Fig. 20. Schematic of a typical steam converter unit. . . . . . 53

21. Conceptual design of the Dow Oxygenation process

using a packed column ................... 55

22. Schematic of geothermal steam power plant using

surface condensers with Stretford $\mathrm{H}_{2} \mathrm{~S}$ abatement ..... 58

23. Schematic of a geothermal steam power plant using

direct contact condensers with the $\mathrm{H}_{2} \mathrm{O}_{2}$

supplemented iron catalyst $\mathrm{H}_{2} \mathrm{~S}$ control system ...... 59

24. Photo of a Stretford plant under construction at

PG\&E's Unit 13, The Geysers . . . . . . . . . 61

25. Flow Diagram of the Stretford process. . . . . . . 62 


\section{LIST OF TABLES}

Table No.

1

Ranges and average values of $\mathrm{H}_{2} \mathrm{~S}$ and other noncondensable gases found in geothermal fluids from wells in

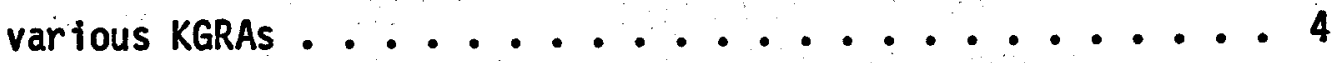

2 Hydrogen sulfide concentration in the steam of individual geysers units ................. 5 Imperial Valley geothermal power projection to 1987 based

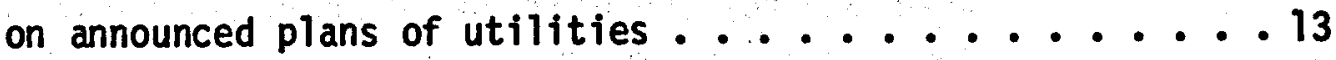
A comparison of "worst case" emissions for various

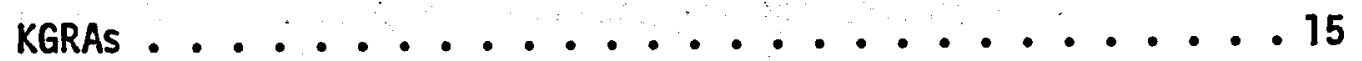
Approximate amounts of $\mathrm{H}_{2} \mathrm{~S}$ emitted to the atmosphere at The Geysers for various release points . . . . . . 17 Union 0 il Company guidelines for curtailing production from geothermal wells during plant outages. ....... 19 Suggested permissible concentrations of $\mathrm{H}_{2} \mathrm{~S}$ in workroom -

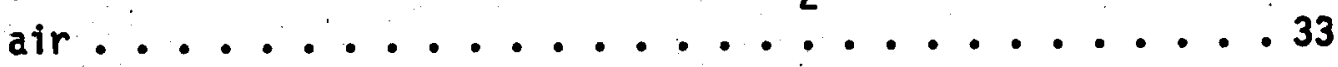
$\mathrm{H}_{2} \mathrm{~S}$ discharge rates for geothermal power plants. ..... 34 $\mathrm{H}_{2} \mathrm{~S}$ discharge rates for steam transmission lines ...... 35 sulfur removal systems ............... 40 Dependence of $\mathrm{H}_{2} \mathrm{~S}$ partitioning on $\mathrm{pH}$ and type of

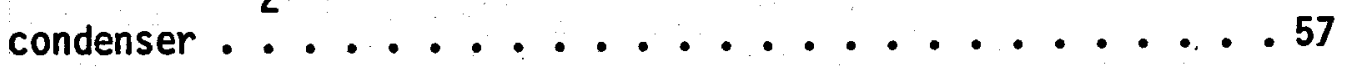
Costs of best candidate technologies .......... 72 Evalution of $\mathrm{H}_{2} \mathrm{~S}$ control proceses. ................ 


\section{INTRODUCTION}

The use of geothermal energy for the production of electric power has been. thought by many to be clean and nonpolluting. There are, however, many environmental issues to be considered in the expanding geothermal industry. These issues include emission of noncondensable gases and salts, subsidence and induced seismicity, liquid wastes, solid wastes, and noise. This report was uritten to complete work initiated in 1977 by Midwest Research Institute concerning state of the art abatement technologies to mitigate emissions of hydrogen sulfide $\left(\mathrm{H}_{2} \mathrm{~S}\right)$ from geothermal installations. It includes an update of $\mathrm{H}_{2} \mathrm{~S}$ control technologies. Some of these technologies have been tried and found economically or operationally inadequate; some are presently being used as abatement systems and are st 111 being evaluated; some are in the experimental and pilot-plant stage for future applications. of these, certain technologies are coming to the forefront as the best candidate technologies for the control of $\mathrm{H}_{2} \mathrm{~S}$ emissions for particular applications in geothermal power systems. Total abatement of $\mathrm{H}_{2} \mathrm{~S}$ emissions is not currently possible and may never be economically feasible. This report calls attention to those best candidate technologies for $\mathrm{H}_{2} \mathrm{~S}$ abatement and suggests additional areas for research.

The main requirement for the use of geothermal resources is that their use be environmentally and economically acceptable. It is the purpose of this report to provide the Department of Energy (DOE) and other concerned agencies with information that will help them to plan the accelerated development of geothermal resources in a manner that will meet environmental constraints and minimize attendant economic penalties.

\section{BACKGROUND}

Hydrogen sulfide abatement techniques are new to electric power generation and must be viewed as experimental or developmental even though similar processes are used in the chemical and petroleum industries. Most of the information in this report relating to applied abatement technology has been obtained from experiences at The Geysers in northern California, the only operating geothermal plant in the United States. This Known Geothermal Resource Area (KGRA) is presently producing $663 \mathrm{MW}$ of electrical energy. Although a unique vapor-dominated resource, abatement experience gained at The Geysers can also be applied to other KGRAs that depend on liquid-dominated resources. 
The term "Best Available Control Technology" (BACT), as currently being applied to technologies that may be effective for $\mathrm{H}_{2} \mathrm{~S}$ abatement, can be misconstrued. It implies, to some, that a proposed technique will effectively control $\mathrm{H}_{2} \mathrm{~S}$ emissions in geothermal applications simply because it is effective in other industrial applications. This is not necesarily the case. Any technology must be researched, designed, developed, and then successfully applied to the particular plant process for perhaps one or two years before its applicability, efficiency, reliability, and costs can be evaluated. Therefore, the development of BACT for $\mathrm{H}_{2} \mathrm{~S}$ abatement in geothermal applications will require concerted effort by participants from both government and industry.

\section{REPORT ORGANIZATION}

To he ip the reader with a clear understanding of the $\mathrm{H}_{2} \mathrm{~S}$ release points in geothermal systems, Sections II and III are devoted to background information on the characteristics of geothermal resources and energy conversion processes. The actual release points are described in Section IV and some technical and legal requirements for the abatement of $\mathrm{H}_{2} \mathrm{~S}$ releases are discussed in Section $V$.

Abatement technologies to mitigate $\mathrm{H}_{2} \mathrm{~S}$ emissions are described in Section VI, with special emphasis on prime candidate methods presently known. Evaluation of the most likely candidates appears in Section VII with a brief discussion of cost estimates. Details of preliminary cost estimates are given in Appendix $B$.

The last section, Section VIII, offers recomendations for research and development for present and future environmental control technologies. 


\section{RESOURCE CHARACTERIZATION}

Hydrothermal resources exist as vapor-dominated resources (steam) or liquid-dominated resources (hot water/brine). At the present time, the only power generation in the United States is taking place at The Geysers (a vapor-dominated resource) in Northern California. In the future, however, the major developments in geothermal power generation in the United States will most likely be in the area of liquid-dominated resources.

\section{VARIABILITY OF RESOURCES}

Geothermal reservoirs, both vapor- and liquid-dominated, are characterized by a significant lack of uniformity, even within the same well field over distances as short as a few kilometers. The emission of $\mathrm{H}_{2} \mathrm{~S}$ from geothermal power plants depends on several factors: the $\mathrm{H}_{2} \mathrm{~S}$ content in the geothermal fluid, the chemical and physical properties of the fluid, and the efficiency of conversion and abatement technologies. The total mass emission from a given KGRA depends on the size of the individual power plants and the total number of power plants throughout the area of development. There is considerable uncertainty in all of these factors, especially with liquid-dominated systems which are only in the initial stages of development.

The variability of geothermal fluids is illustrated in Table 1 by the range and average values of noncondensable gases found in several geothermal resources. The average values shown for The Geysers KGRA are fairly reliable because of the experience gained over many years of operation and the large number of analyses performed on samples from many wells. Hydrogen sulfide concentrations in the steam of individual Geysers units is shown in Table 2. Although many wells (10 to 20) supply each power generating unit, it can be seen that the spatial variations are significant. In addition, temporal variations are also fairly comnon; data from The Geysers KGRA reflect a two-fold variation over a period of a few months. ${ }^{12}$ Data shown in Table 1 for various KGRA's in the Imperial Valley are the results from a limited number of samples taken from a few wells in each area. When actual power 
TABLE 1. Ranges and average values of $\mathrm{H}_{2} \mathrm{~S}$ and other noncondensable gases found in geothermal fluids from wells in various KGRA's. Values are in $\mathrm{mg} / \mathrm{kg}$ of fluid (ppmw).

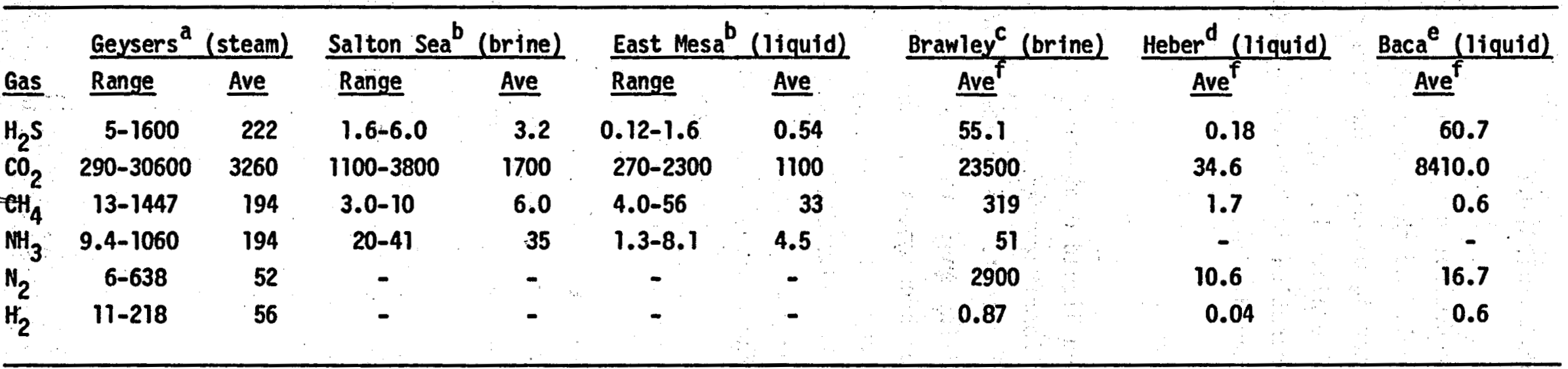

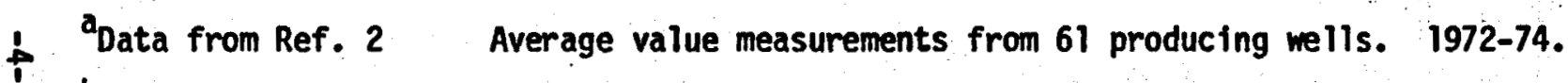

bata from Rev. 3 Measurements from 2 or 3 wells.

CData from Ref. 4 Average of 2 wells: Veysey 2 and TOH 1.

Data from Refs $5 \& 6$ Average of 2 weils

Data from Ref. 7 (Baca Ranch, Sandoval County, New Mexico)

$f_{\text {Meaningful range data not available. }}$ 
TABLE 2. Hydrogen sulfide concentrations in the steam of individual Geysers units.

\begin{tabular}{lcc}
\hline Unit & Rated net power & (MW) \\
\hline 1 & 11 & $\mathrm{H}_{2} \mathrm{~S} \begin{array}{c}\text { concentration } \\
\text { (ppmw) }\end{array}$ \\
\hline 2 & 13 & 170 \\
3 & 27 & 170 \\
4 & 27 & 450 \\
5 & 53 & 570 \\
6 & 53 & 280 \\
7 & 53 & 250 \\
8 & 53 & 230 \\
9 & 53 & 160 \\
10 & 53 & 110 \\
$11^{\mathrm{b}}$ & 106 & 100 \\
$12^{\mathrm{c}}$ & 106 & 258 \\
$13^{\mathrm{d}}$ & 135 & 90 \\
$14^{\mathrm{d}}$ & 110 & - \\
$15^{\mathrm{e}}$ & 55 & - \\
& & 130 \\
\hline & & \\
\hline
\end{tabular}

Note: Data for all units except 11 and 12 from Weinberg. 9 Accuracy of the values $\pm 20 \%$.

a Table adapted from Ref. 8.

buit 11 value from Ref. 10.

Unit 12 value from Ref. 11 .

dunits not yet in existance.

Unit 15 coming on-line as of this writing. 
production in the Imperial Valley becomes significant (hundreds of MWe) and operational experience and additional data are accumulated, the source measurements may show significantly different $\mathrm{H}_{2} \mathrm{~S}$ concentrations.

\section{ENERGY CONVERSION TECHNOLOGIES AND PLANT DESIGN}

\section{CONVERSION TECHNOLOGIES}

Several conversion technologies have been proposed to produce electricity from geothermal fluids. In general, these processes involve the use of a high-enthalpy fluid to drive a turbine/generator. In a vapor-dominated system such as The Geysers, geothermal steam is used directly in the turbine. Although there are no power plants now operating on liquid-dominated systems in the United States, processes are now being developed. These include: flashed steam, flashed-steam binary cycle, hot water binary cycle, and total flow. Geothermal fluids may also be used as a direct source of heat for nonelectrical applications such as space heating and process heating. Some of the processes in current use and under development for both direct use and electrical power generation are discussed below.

\section{DIRECT STEAM POWER GENERATION}

Vapor-dominated systems produce electrical power directly by expanding the geothermal steam through a turbine that is coupled to a generator (Fig. 1). A centrifugal separator, upstream of the turbine, removes particulate matter and water. The turbines are designed to operate on the relatively low temperatures and pressures of geothermal steam compared to the much higher temperatures and pressures of steam used with turbines in conventional fuel-fired power generating plants. The spent steam from the turbine is condensed in a direct-contact condenser or a surface condenser. This condensation reduces the pressure on the downstream side of the turbine to subatmospheric pressure and thus increases the turbine efficiency. The condenser is equipped with steam-jet ejectors to expel noncondensable gases 
into the atmosphere. (Noncondensable, in this context, means not condensed under the existing operating conditions of temperature and pressure.) The condenser fluid (condensate and cooling water in the case of a contact. condenser or simply condensate in the case of a surface condenser) is pumped to a forced-draft cooling tower. After cooling, the water is returned to the condenser to cool incoming steam. At The Geysers, cooling tower blowdown is deep injected for reservoir recharge.

The noncondensable gases contain part of the $\mathrm{H}_{2} \mathrm{~S}$, but part is also present in the condensate. Partitioning of $\mathrm{H}_{2} \mathrm{~S}$ between noncondensable gases and condensate depends on the chemical characteristics of the fluid and the condenser design. Thus, it may be necessary to treat both the condensate and the noncondensable gases to provide effective $\mathrm{H}_{2} \mathrm{~S}$ abatement. Hydrogen sulfide release points are indicated in Fig. 1.

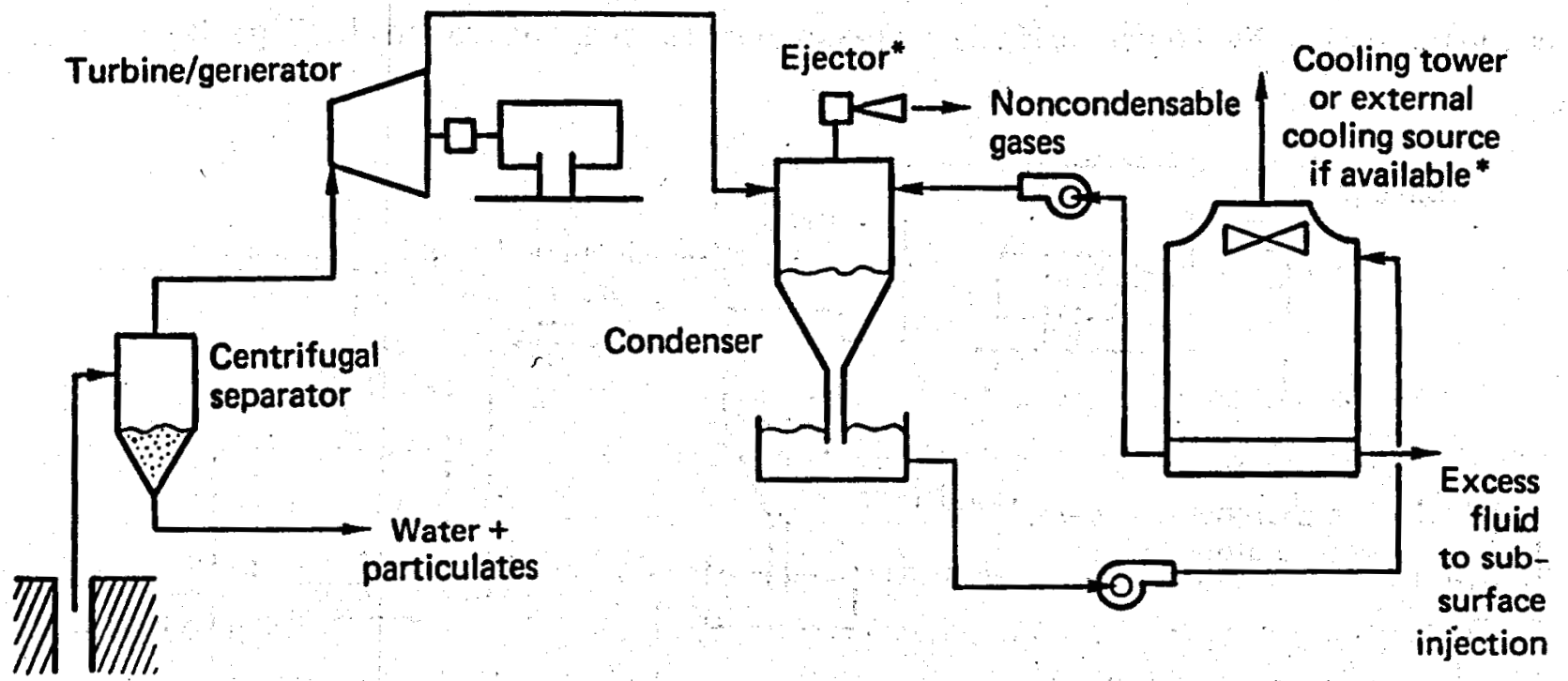

Steam well.

FIG. 1. Direct-steam process. *Hydrogen sulfide release point 
Liquid-dominated resources require flashing of the geothermal fluid to produce steam, as shown in Fig. 2. Flashing is a process whereby the superheated well fluid is allowed to boil at a pressure that is lower than its equilibrium subterranean pressure. If the flashed liquid is hot enough, it can be flashed again in subsequent stages to produce additional steam. The flash chamber serves a dual purpose, also acting as a centrifugal separator to remove water and particulates from the steam. Once the steam is formed, it is then used for power generation as described above for direct-steam power generation. The spent liquid may be injected underground together with the cooling-tower blowdown fluid.

The lower pressure required for 7 lashing decreases the solubility of the gases dissolved in the liquid. The result is that the hot fluid is transformed into two phases, a liquid phase containing some dissolved gases and a vapor phase containing steam plus most of the noncondensable gases including $\mathrm{H}_{2} \mathrm{~S}$. Hydrogen sulfide release points are indicated in Fig. 2.

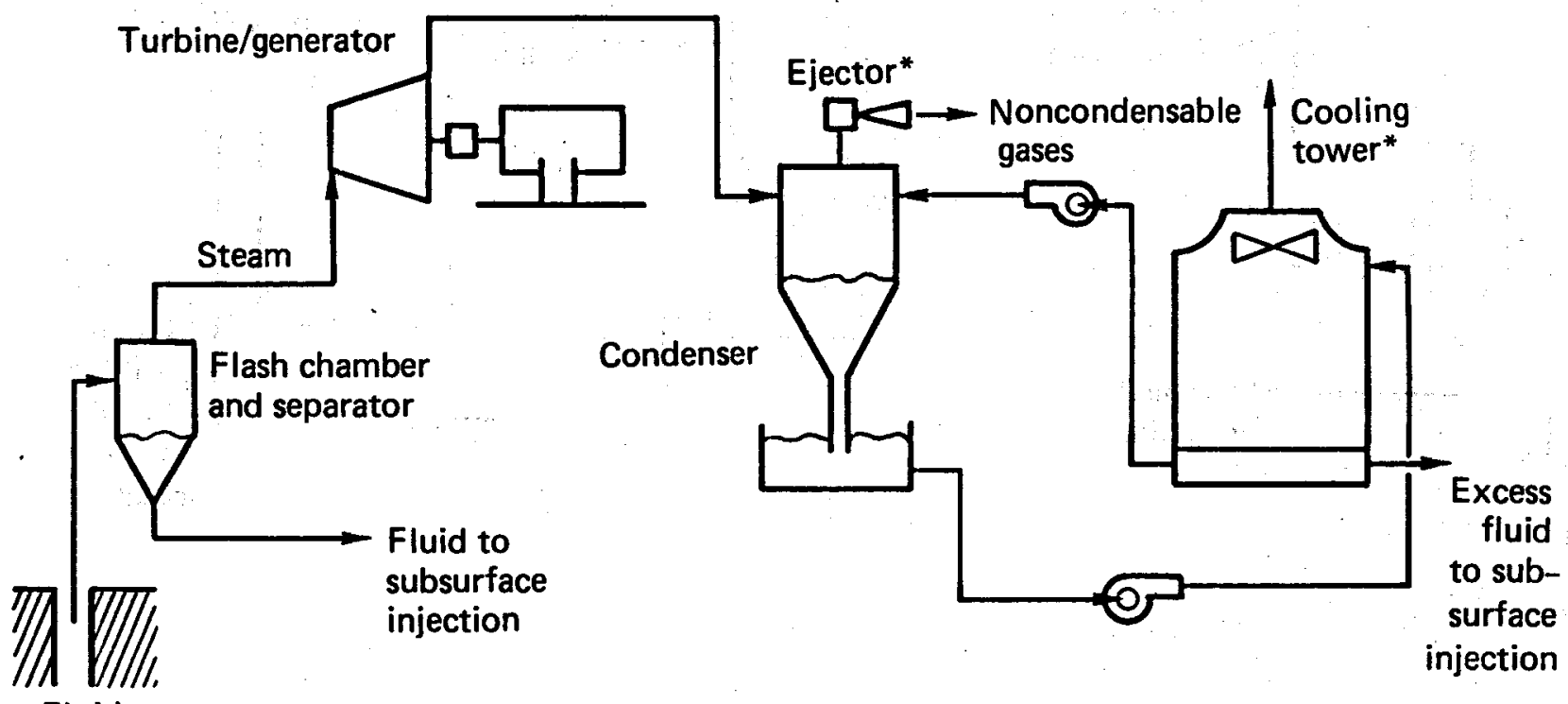

Fluid

well

FIG. 2. Flashed-steam process. Separator discharge liquid can be flashed again if its temperature is sufficiently high. *Hydrogen sulfide release point. 
This process uses the steam from flashed geothermal brine (as shown in Fig. 3) which, when passed through heat exchangers (boiler and superheater), vaporizes a low-boiling secondary fluid such as isobutane. The high-pressure secondary fluid is used to generate power by means of a turbine/generator unit as before. The secondary fluid (vapor) exhausted from the turbine is condensed and returned at high pressure to the heat exchanger. The spent steam from the heat exchangers is condensed and the noncondensable gases are removed. The steam condensate is then cooled in a cooling tower and recycled as a coolant for the condensers. Hydrogen sulfide release points are indicated in Fig. 3.

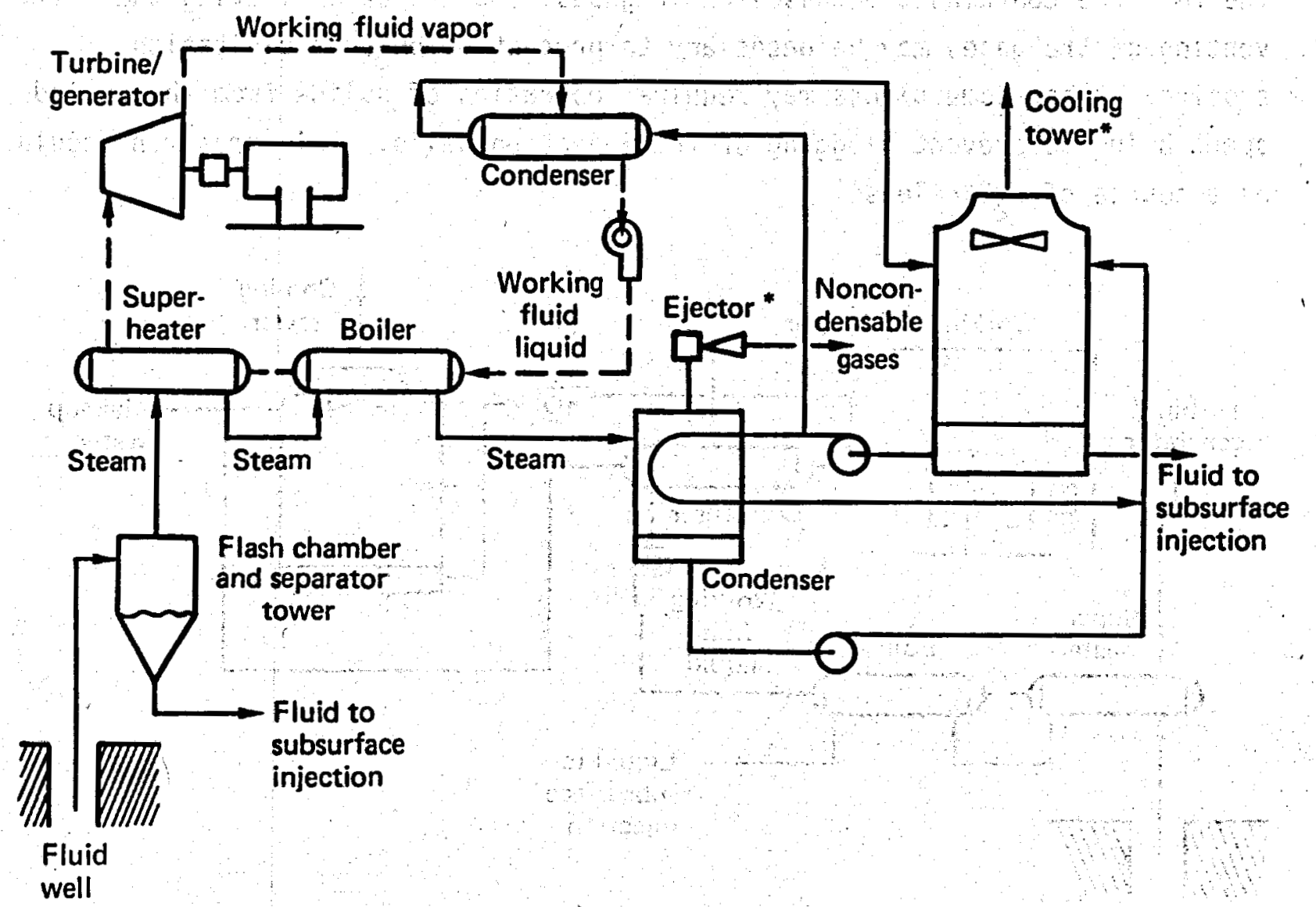

FIG. 3. Flashed binary cycle process. Flashed steam is used to heat a secondary fluid. "Hydrogen sulfide release point. 
This process is similar to the flashed binary cycle except that the hot geothermal fluid is used directly to vaporize the secondary fluid (Fig. 4). The heat from the hot well fluid is transferred to the secondary fluid by a countercurrent flow through a boiler and superheater. After expanding through the turbine, the secondary fluid is condensed with water from a cooling tower and pumped to the heat exchangers at a high pressure. The cooling water used in this process must be supplied by an outside source since no steam condensate is generated for cooling purposes. The entire spent geothermal brine is injected underground.

It is generally believed that noncondensable gases are not emitted from binary cycle hot water systems because flashing is not required. However, if the resource contains two phases or if gases separate after leaving the we11, venting of the gases may be necessary to protect pumps from cavitation erosion. Also, some plants may require separation of solids from the cooled spent brine to prevent plugging of the injection wells. This treatment could be a source of $\mathrm{H}_{2} \mathrm{~S}$ release.

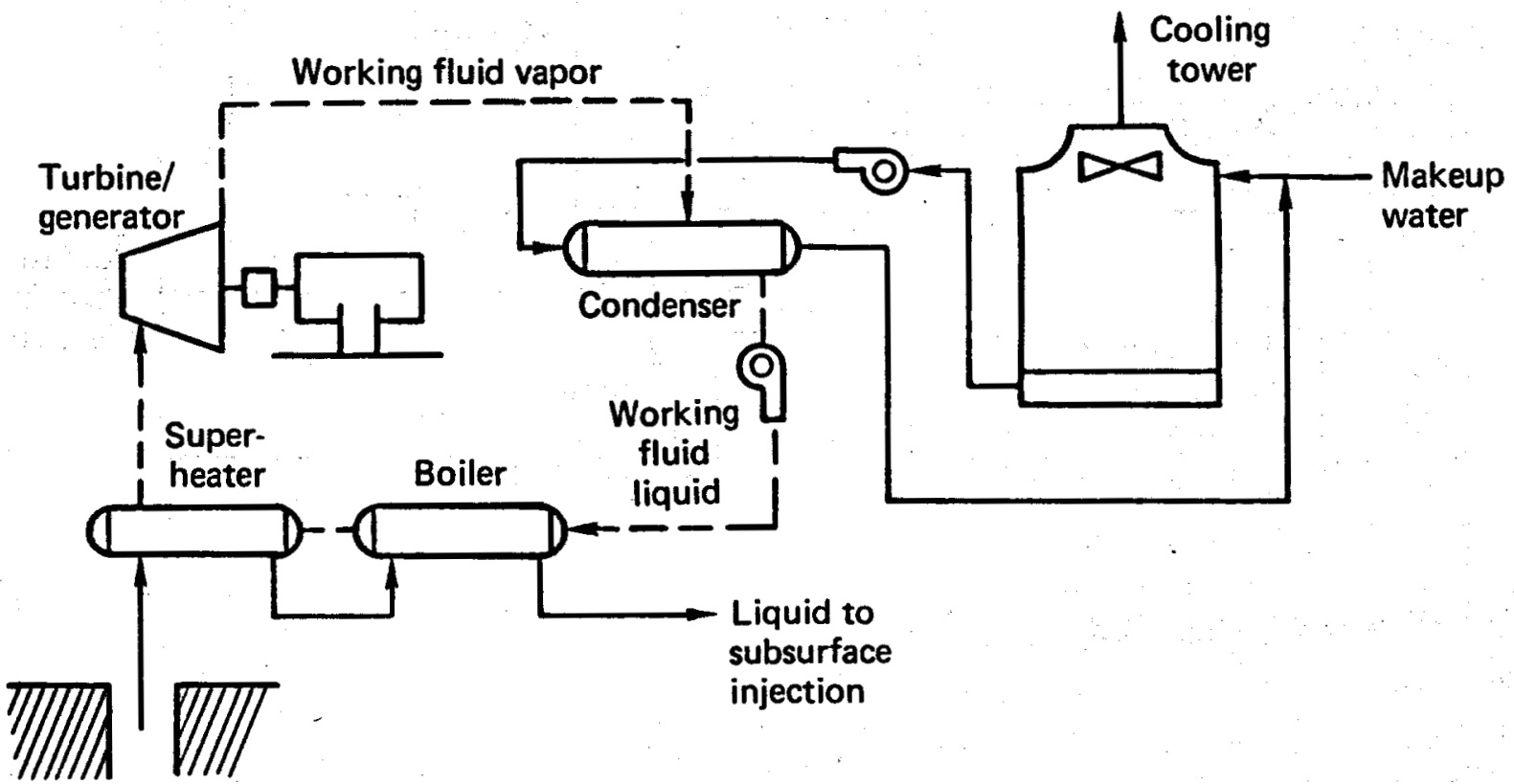

Fluid

well

FIG. 4. Binary cycle (hot water) process. Hot water is used to heat a secondary fluid. 
Total-flow systems are examples of the use of liquid geothermal resources that do not depend on the transfer of heat energy to another working fluid, but rather convert the thermal energy to kinetic energy. This process is shown in Fig. 5. The kinetic energy is utilized in two types of specially designed turbines: the impulse turbine and the reaction turbine. The impulse system obtains energy by impingement of vapor on the blades of a rotor, while the reaction system depends on the reaction of high velocity jets much as in pyrotechnic pinwheel displays. Lawrence Livermore Laboratory (LLL) has been working on both types of systems. 13

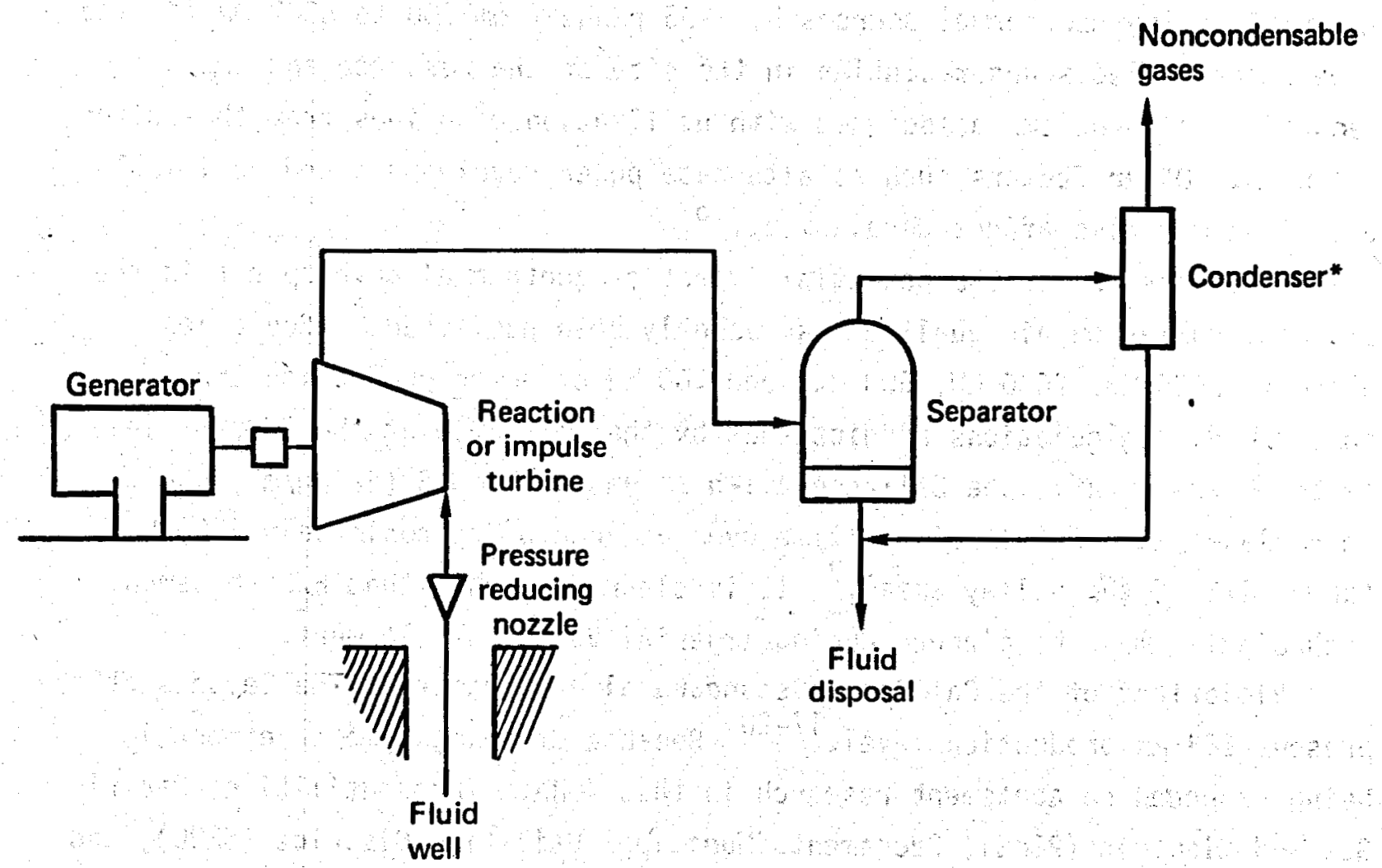

FIG. 5. Total Flow Process. *Hydrogen sulfide release point 
Except for The Geysers, there are no geothermal electric power facilities in the United States. A unit scheduled to come on-line this year is the Magma $10 \mathrm{MW}$ plant in the Imperial Valley East Mesa KGRA. The facility will be operated by the San Diego Gas and Electric Company (SDG\&E). This plant will use a binary cycle (hot water) process.

Several other geothermal facilities of SDG\&E, Southern California Edison (SCE) and California Department of Water Resources (DWR) are proposed for electric power production in the near future. Forecasts for the period from 1979 to 1987 are assembled in Table 3. Several hundred megawatts of electric power production is projected. Estimates of electric power available from Imperial Valley geothermal sources by 1995 range from 500 to $8000 \mathrm{MW} .^{15}$ The wide range reflects uncertainties in the size of the resource and the technological problems associated with utilization of brines from the Salton Sea KGRA. Other factors such as alternate power development and political decisions may also affect development. ${ }^{16}$

An assessment of the potential impact of geothermal development in the Imperial Valley on air quality has recently been published. ${ }^{3}$ Scenarios based on $30,00 \mathrm{MW}, 2000 \mathrm{MW}, 500 \mathrm{MW}$, and $100 \mathrm{MW}$ of power production are considered. Calculations predict that by the year 2010 at the 3000-MW leve 1 (with no abatement), the California $1-h$ standard for $\mathrm{H}_{2} \mathrm{~S}\left(42 \mu \mathrm{g} / \mathrm{m}^{3}\right)$ would be violated at least $1 \%$ of the time over an area of approximately $1500 \mathrm{~km}^{2}$ (about $1 / 3$ of the valley area). ${ }^{3}$ It is clear from this that $\mathrm{H}_{2} \mathrm{~S}$ abatement technologies must be planned during Imperial Valley development.

Violations of the California standard already exist at The Geysers at the present $663 \mathrm{MW}$ production level. ${ }^{17-20}$ Because of this, a major effort is being expended on abatement research in this KGRA. Three utilities, Pacific Gas and Electric (PG\&E), Sacramento Municipal Utilities District (SMUD), and Northern California Power Association (NCPA), indicate that 2708 MW of electricity could be produced at The Geysers by 1990 .

It is apparent that without sufficient preplanning for $\mathrm{H}_{2} \mathrm{~S}$ abatement procedures, the generation of electric power from geothermal resources can be (and is) a source of air pollution. 
TABLE 3. Imperial Valley geothermal power projection to 1987 based on announced plans of utilities. ${ }^{a}$.

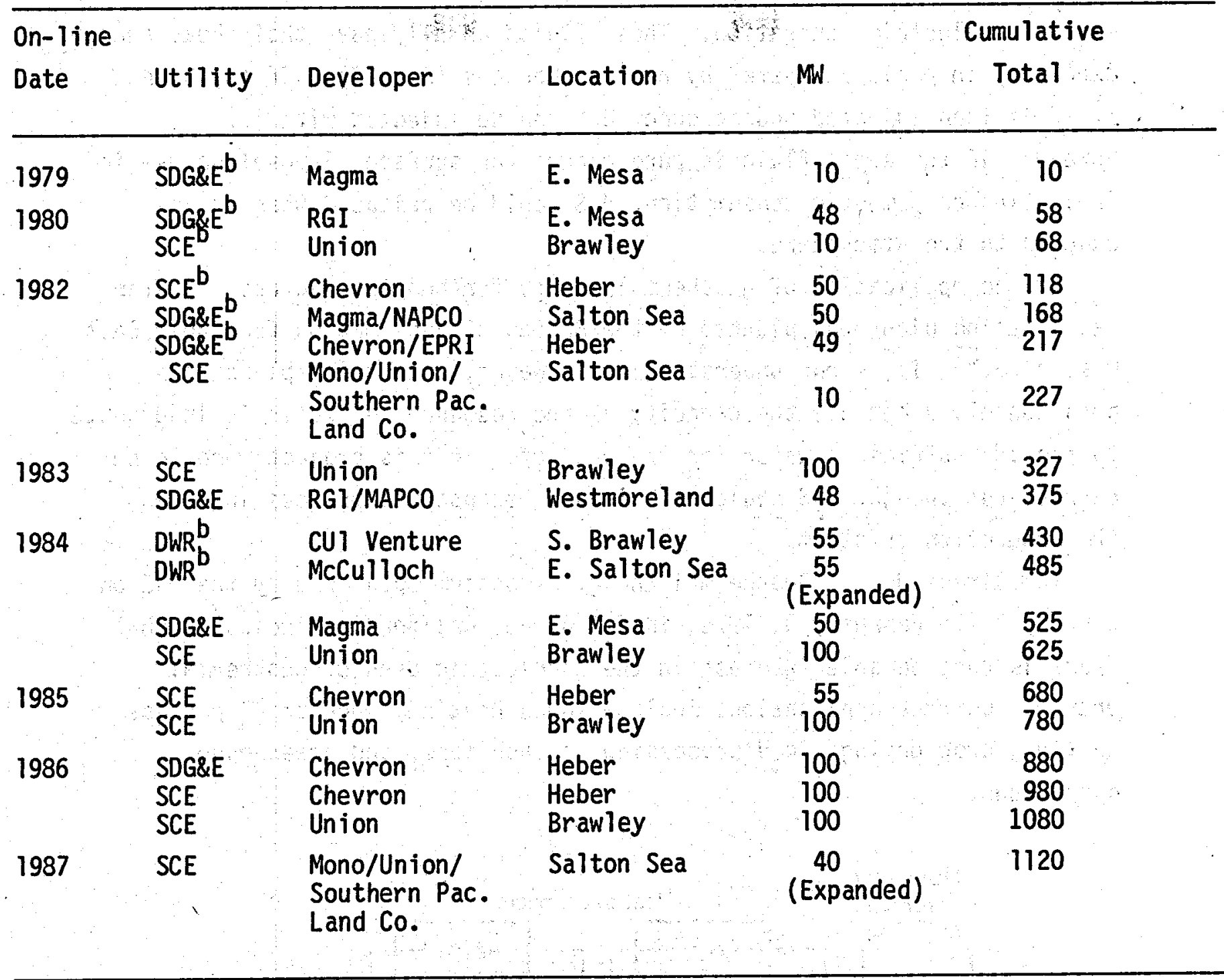

$a_{\text {From Ref. } 14 .}$

${ }^{b} A$ comitment has been made between utility and developer. 
In general, the geothermal energy for nonelectric use is provided by liquid resource fluids that have an enthalpy (heat content) too low for efficient electric generation. These fluids usually have their heat energy extracted in a closed system, by heat exchangers (Fig. 6). If the spent fluid is then injected underground, $\mathrm{H}_{2} \mathrm{~S}$ can be injected with it. However, if the spent fluid is pure enough for surface disposal or use in irrigation or domestic consumption, $\mathrm{H}_{2} \mathrm{~S}$ could be released when it is exposed to the atmosphere.

In one application of geothermal energy for nonelectric use, a water desalination plant was planned by the Bureau of Reclamation for their East Mesa site. ${ }^{21}$ It is our understanding, however, that these plans have been cancelled because the capacity of the resource reservoir is inadequate to provide sufficient water for the project. If this project were to be carried out though, $\mathrm{H}_{2} \mathrm{~S}$ could be released because the process involves the production of steam.

The Direct Use of Geothermal Energy Symposium sponsored by the DOE on January 31 to February 3, 1978, in San Diego, California, indicated that there is considerable interest in the nonelectric uses of geothermal energy. Current applications include space heating, industrial process heating, crop drying, food processing, aquaculture, and greenhouse operations.

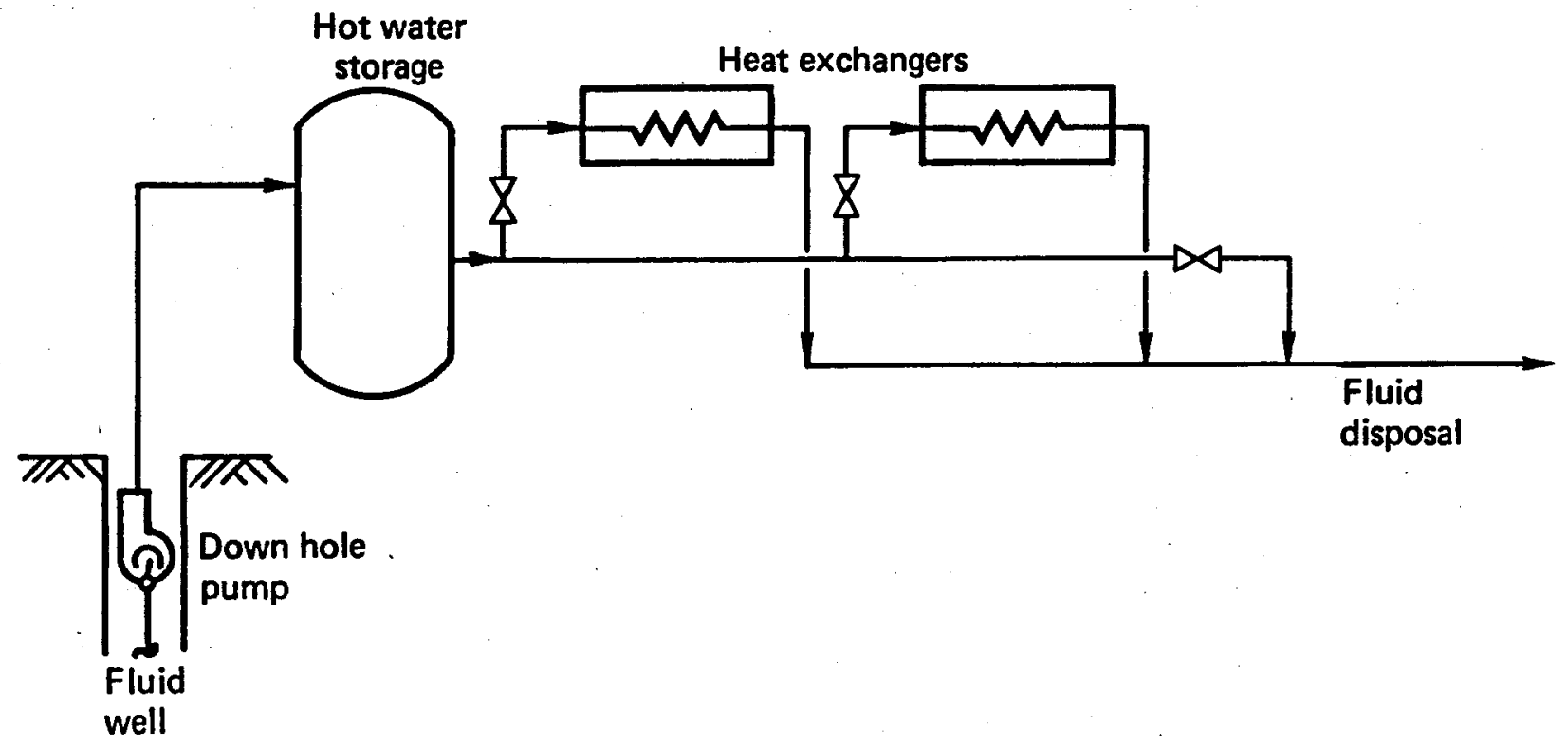

FIG. 6. Direct heating (closed system). 
The release points for $\mathrm{H}_{2} \mathrm{~S}$ can be divided into two categories: those which occur upstream of the turbine (pre-plant emissions) and those which occur downstream of the turbine (power-plant emissions). The pre-plant emissions include releases from well field construction and operations such as drilling, well testing, pipeline venting, steam stacking, and well bleeding while on standby. Sources of downstream emissions depend on the conversion process and include both the steam condensate and noncondensable gas streams. These major release points of $\mathrm{H}_{2} \mathrm{~S}$ for several conversion processes have been previously. indicated in Figs. 1 to 5 .

\section{A VAPOR-DOMINATED PLANT - THE GEYSERS}

Table 5 lists the approximate amounts of $\mathrm{H}_{2} \mathrm{~S}$ emitted to the atmosphere at The Geysers geothermal development for release points with and without downstream abatement. A brief description of the various points where $\mathrm{H}_{2} \mathrm{~S}$ is released during the construction and operation of a typical power plant at The Geysers is given below. ${ }^{23}$ A more detailed description of The Geysers plant operations appears in Ref. 24.

\section{Pre-plant Emission}

The geothermal resource under development at The Geysers KGRA is rare because it consists of steam rather than hot water. The initial emissions occur when wells are drilled. During the first stages of drilling, mud is used to cool and lubricate the drill bit. However, when the drill reaches the geothermal stratum, the high temperatures encountered can cause caking of the mud which can plug the steam-producing formation. At this point the use of mud is discontinued and air-drilling techniques are used. During this drilling phase the geothermal fluid is released to the atmosphere. Releases during well drilling typically continue for 1 to 3 wk. Normally, only one well at a time will be at this stage of operation; occasionally, two or perhaps three wells are at this stage. 
TABLE 5. Approximate amounts of $\mathrm{H}_{2} \mathrm{~S}$ emitted to the atmosphere at The Geysers geothermal development for various release points.

\begin{tabular}{|c|c|c|c|c|c|}
\hline \multirow[b]{2}{*}{ Release points } & \multirow{2}{*}{$\begin{array}{l}1976 \text { unabated, } \\
\mathrm{H}_{2} \mathrm{~S} \text { emissions, } \\
\mathrm{kg} / \mathrm{h}\end{array}$} & \multirow{2}{*}{\multicolumn{2}{|c|}{$\begin{array}{l}\frac{\text { Without abatement }}{\text { Percent of }} \\
\mathrm{kg} / \mathrm{h} \quad \text { Total }\end{array}$}} & \multicolumn{2}{|c|}{$\begin{array}{l}\text { With } 90 \% \text { downstream } \\
\text { abatement }\end{array}$} \\
\hline & & & & $\mathrm{kg} / \mathrm{h}$ & $\begin{array}{l}\text { rcent of } \\
\text { total }\end{array}$ \\
\hline Total power plant emissions & 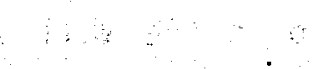 & $1152^{b}$ & 90.8 & $115^{b}$ & 49.6 \\
\hline Pre-plant emissions & & & & & \\
\hline Well drilling & 4 & $5^{c}$ & 0.4 & $5^{c}$ & 2.2 \\
\hline Testing \& clean-out & 13 & $17^{c}$ & 1.3 & $17^{c}$ & 7.3 \\
\hline Well bleeds & 3 & $4^{c}$ & 0.3 & $4^{c}$ & 1.7 \\
\hline Steam stacking & 28 & $37^{c}$ & 2.9 & $37^{c}$ & 15.9 \\
\hline Pipeline vents & 14 & $19^{c}$ & 1.5 & $19^{c}$ & 8.2 \\
\hline Uncontrolled well & 33 & 33 & 2.6 & 33 & 14.2 \\
\hline Natural fumaroles & 2 & $\underline{2}$ & 0.2 & 2 & 0.9 \\
\hline Total pre-plant & & 117 & 9.2 & 117 & 53.4 \\
\hline Total emissions & $\therefore$ & 1269 & 100.0 & 232 & 100.0 \\
\hline
\end{tabular}

a From Ref. 22 (1976).

bestimated for $1979663 \mathrm{MW}$ total generating capacity: $1.83 \times 663 \times 0.95=1152$.

where

$1.83=\mathrm{kg} \mathrm{H}$ S/MWh from Table 4 ,

and $\quad 0.95=$ emission factor ( $H_{2} S$ in source fluid actually emitted).

CValue from Ref. 22 multiplied by 1.33 to est imate 1979 value. 
After a well-drilling operation is completed and valves have been installed, there is an initial 1 to 2 wk cleaning step to remove solids ("rock dust") accumulated in the reservoir during drilling. Then the well is flow tested. The purpose of the flow test is to determine production capacity. Flow testing may require from 4 to $24 \mathrm{~h}$ with flows ranging from 25 to $100 \%$ of full capacity. (Flow testing is required for all geothermal wells, regardless of the type of fluid, so $\mathrm{H}_{2} \mathrm{~S}$ control may be required at virtually all fields.)

When the flow test has been completed, the well is allowed to bleed (vent) through a bleed pipe. The purpose of such standby venting is to maintain a high temperature along the entire length of the well casing. A decrease in temperature would cause the casing to contract and separate from the grout that cements the casing to the wall of the rock formation. A fracture of the well casing could cause a blowout. Venting is therefore prudent because the cost for drilling and completion of a production well averages about one million dollars. ${ }^{25}$ The well is allowed to bleed until a power plant is constructed; it may remain in this condition for several years, although most production wells are drilled during the latter stages of plant construction.

After a power plant is built and in operation, venting still routinely occurs at several locations along the steam supply lines. In an operating plant, however, most of these vents have been connected to a vent collection system, and the condensed geothermal fluid is now injected back into the ground. These vents are small (3/8 in. or less) and are located at particle separators that remove particles at the wellhead, at flow meters along the steam lines, at low spots along the line where condensate is periodically removed, and at the dust particle separator near the plant entrance. These vents are of relatively minor importance at present, but they do release all the geothermal fluid without removal of any pollutants.

The major release associated with the steam supply occurs when the power plant goes down. When a malfunction is detected in the plant, the supply of steam to the turbine is shut off; this causes pressure to build up quickly in the lines. This pressure build up in the transmission line actuates relief valves sequentially, and the full flow of geothermal fluid is vented directly into the atmosphere (steam stacking) through a muffler 
to reduce noise. The Union 0 il Company has developed procedures for use in the event of power plant outages to curtail production from the geothermal wells; such curtailment reduces emissions by throttling down wells and redistributing steam to adjacent operating power plants. These procedures are sumarized in Table 6 .

TABLE 6. Union 0il Co. guidelines for curtailing production from geothermal wells during plant outages.

Expected duration of unit shutdown
Action to be taken
Less than $2 \mathrm{~h}$

2 to $24 \mathrm{~h}$

24 to $96 \mathrm{~h}$

More than $4 d$
Adjust steam apply to maximum vent pressure Adjust steam supply to maximum vent pressure; throttle wells equipped with vee-ball valves in unit area to a well thead flow pressure of 300 psig

Adjust steam supply to maximum vent pressure; throttle wells equipped with vee-ball valves in unit area to fully closed position (this will reduce flow from we 11 to approximately $20 \%$ of capacity); adjust crossover piping to maximize steam transfer to adjacent unit areas; throttle wells equipped with vee-ball valves in adjacent unit area as required to balance steam supply with demand

Same procedures as used for $24-96 \mathrm{~h}$; in addition, wells will be shut-in as required in affected and adjacent unit areas to el iminate steam venting.

Data supplied by Warren Smith of Union 0il Company 
Under normal conditions at The Geysers geothermal power plants, steam passes through the turbine that drives the generator. After passing through the turbine, the geothermal fluid moves into a direct-contact condenser (Units 1-12). The hot fluid that collects in the condenser is pumped to a cooling tower, while the noncondensable gases are pumped from the condenser by a gas ejector. The noncondensable gases were formerly emitted directly into the atmosphere; with recent modifications to the plants however, they are now injected into the cooling tower. In the cooling tower, about $80 \%$ of the condensed incoming steam is evaporated. The remaining $20 \%$ collects in the cooling tower basin and serves as condenser coolant and blow-down water for solids control. The blow-down is injected into the geothermal reservoir through an injection well.

Pacific Gas and Electric has taken samples from the steam inflow at each power plant unit and measured the concentrations of $\mathrm{H}_{2} \mathrm{~S}$, ammonia $\left(\mathrm{NH}_{3}\right.$, and boron (B). In passing through the power plant, each of these substances undergoes processes that can affect their rates of emission. From its special measurements of the concentrations and flow rates in the inflow steam, the cooling-tower blowdown, and the cooling-tower exhaust, PG\&E has obtained data on the fractions of the input substances that are emitted into the atmosphere. The data from these measurements are used to translate the routinely measured pollutant inflows into the reported emission rates. These data are summarized in Fig. 7. The fractional dispositions may be different for the various pollutants, however, depending on their physical characteristics and the $\mathrm{pH}$ of the condensate.

The special mass flow and balance measurements show that a normally operating, unabated plant emits about $95 \%$ of the input $\mathrm{H}_{2} \mathrm{~S}$; the remaining 5\% is apparently oxidized or injected. Although this emitted fraction depends to a degree on atmospheric and operating conditions and on $\mathrm{NH}_{3}$ concentrations in the fluid, it is always high. Therefore, the emission rates for unabated plants, which are reported as $95 \%$ of the measured inflow of $\mathrm{H}_{2} \mathrm{~S}$, are accurate within about $15 \%$. 


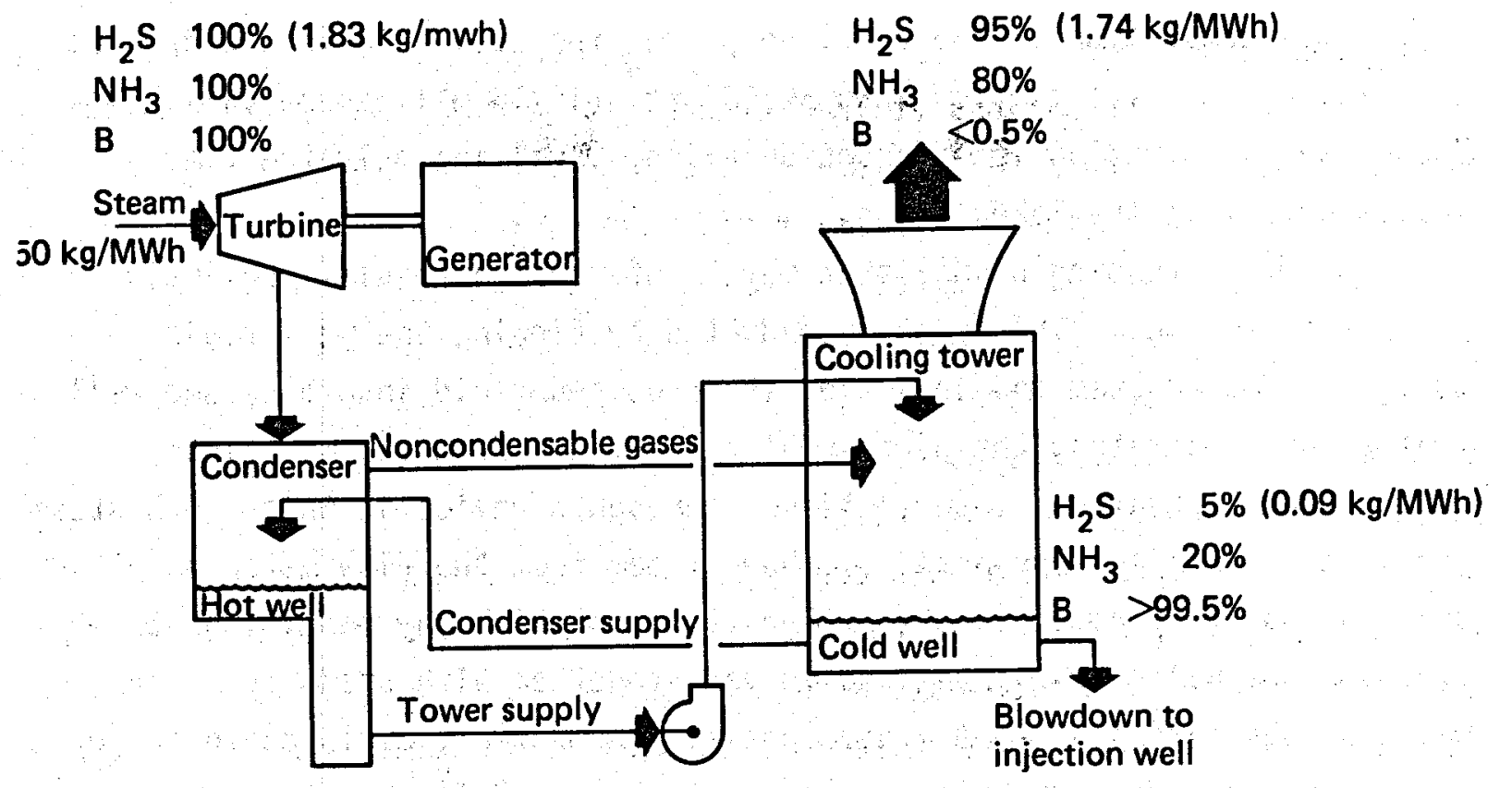

FIG. 7. Typical flow of steam through an unabated power plant showing the distribution of $\mathrm{H}_{2} \mathrm{~S}, \mathrm{NH}_{3}$ and $\mathrm{B} .{ }^{23}$

\section{A LIQUID-DOMINATED FLASHED STEAM PLANT}

The description of a plant now under construction in the Imperial Valley of California will serve to illustrate the release points of $\mathrm{H}_{2} \mathrm{~S}$ from a liquid-dominated resource using a flash system for steam production. The plant is the $10 \mathrm{MW}$ geothermal demonstration facility near Brawley which will be operated by SCE using steam supplied by the resource developer, the Union 011 Company. The information was obtained from Ref. 4.

\section{Pre-plant emissions}

As with The Geysers, initial emissions may occur when wells are drilled. These emissions will probably be negligible since air drilling is not used for this type of resource. Drilling is done with a viscous fluid called "mud" to carry cuttings to the surface, cool and lubricate the drill bit, and counteract reservoir pressures. A sump is used to contain the dripling mud and cuttings. Geothermal fluids acquired during drilling are stored onsite in steel Baker tanks. These stored fluids are then concentrated by evaporation, a minor source of $\mathrm{H}_{2} \mathrm{~S}$ release, and then taken to a Class I or Class II- I disposal site (Appendix C). 
After completion of the drilling phase, the well bore is cleaned out by allowing the well to flow into $50,000 \mathrm{ft}^{3}\left(1,416 \mathrm{~m}^{3}\right)$ Baker tanks. The cleanout operation is of short duration, involving only the time required to fill the Baker tanks.

The first venting of $\mathrm{H}_{2} \mathrm{~S}$ that may be of concern results from well production testing. The test is conducted by flowing the well fluid through a test system and injecting the produced fluid into a second well. In the test apparatus, the geothermal fluid flows from the well into water/steam separators, then continues through a device in which both steam and water flow rates are metered. Downstream from the flow meter is a primary flash separator (with muffler) through which any remaining steam from the hot water is flashed and vented, together with steam from the wellhead separators, into the atmosphere. The water travels on to surge tanks, and is then pumped into a nearby injection well where it reenters the geothermal reservoir. The duration of such a test may range from $12 \mathrm{~h}$ to several months. It is estimated that during testing, $9.1 \mathrm{~kg} / \mathrm{h} \mathrm{of} \mathrm{H}_{2} \mathrm{~S}$ $(218 \mathrm{~kg} / \mathrm{d})$ could result as a "worst case" release (Ref. 4, p. 146).

After well testing has been completed, up to four wells will be used to provide sufficient steam to the power plant. Fluid from each well will be connected to a comon manifold that will convey the fluid to a steam production system. Figure 8 shows a schematic of the entire plant and includes projected flow balances, including $\mathrm{H}_{2} \mathrm{~S}$. At the steam production system, the fluid will be processed to separate the steam phase from the liquid phase and to separate the bulk of the noncondensable gases from the steam. The noncondensable gases will be vented to the atmosphere through the cooling tower.

\section{Power Plant Emissions}

The production steam is piped to the turbine and the exhaust steam is condensed on the shell-side of a surface condenser. Noncondensable gases from the condenser are also vented to the atmosphere via the cooling tower. The "worst case" $\mathrm{H}_{2} \mathrm{~S}$ emissions from the $10 \mathrm{MN}$ plant would include $\mathrm{H}_{2} \mathrm{~S}$ from both the steam production system $(23.4 \mathrm{~kg} / \mathrm{h})$ and the condenser $(1.6 \mathrm{~kg} / \mathrm{h})$, amounting to $25 \mathrm{~kg} / \mathrm{h}$. 


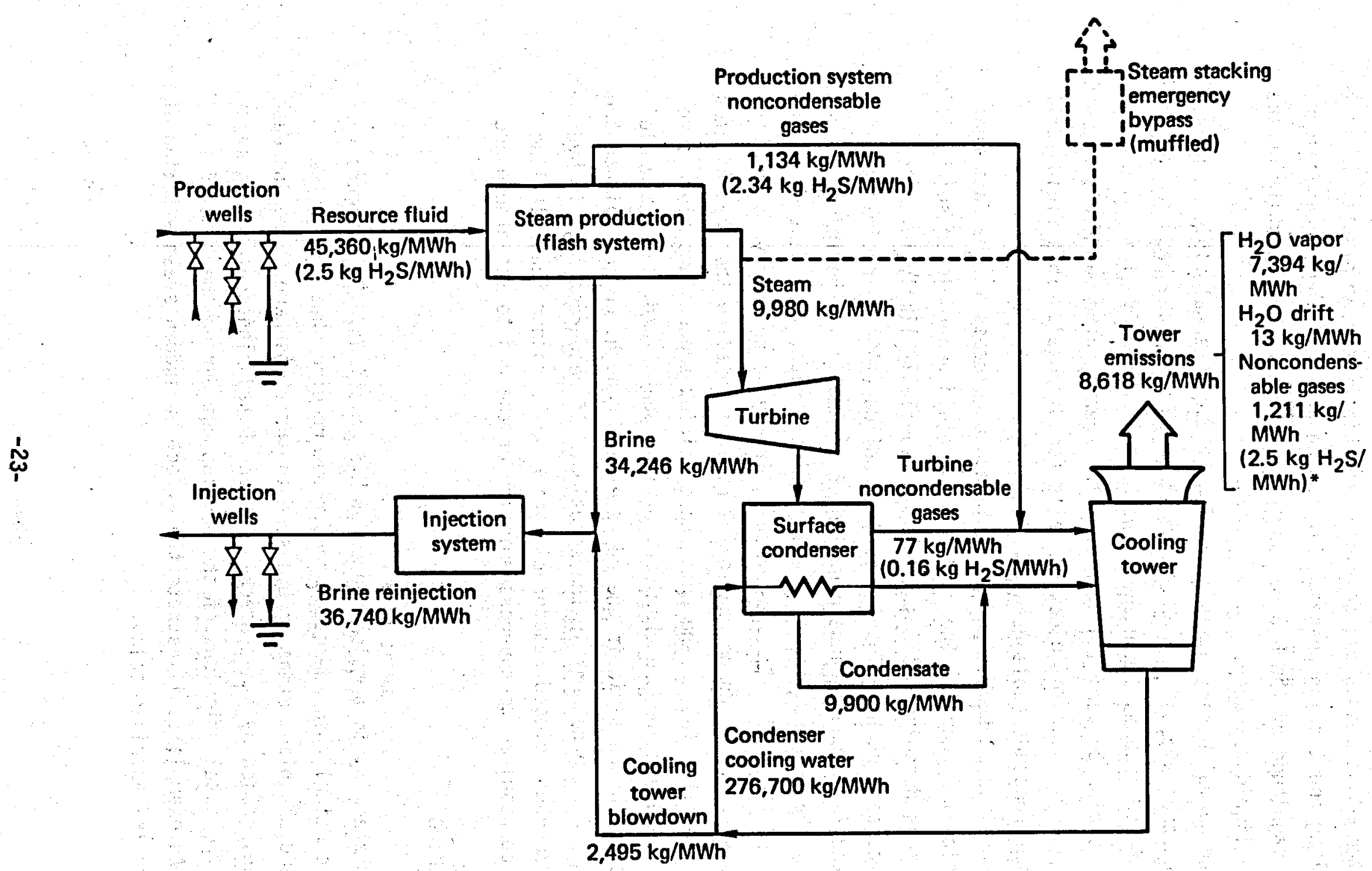

FIG. 8. Schematic of a power plant utilizing a liquid dominated resource to produce flashed steam. (Adapted from Ref. 3, p. 37) *Assuming all gases èmitted. 
The only similarity of $\mathrm{H}_{2} \mathrm{~S}$ emissions between fields developed for flash system plants and those developed for binary system plants, is in the well drilling and testing phases. Since standard drilling procedures are used, the magnitude of the $\mathrm{H}_{2} \mathrm{~S}$ release will depend on the quantity of the gas in the liquid resource.

During normal binary plant operation, the geothermal fluid is passed through the tube side of a heat exchanger to transfer the heat energy to a secondary fluid such as isobutane. The heated secondary fluid is expanded through a turbine to turn a generator. The spent geothermal fluid from the heat exchanger is sent to injection wells for disposal. This fluid still contains the noncondensable gases including $\mathrm{H}_{2} \mathrm{~S}$.

One possible perturbation to the injection process is the fact that precipitation may occur in the cooled spent fluid due to lower solubilities of the various dissolved solids. This is especially likely in those resources containing high Total Dissolved Solids (TDS). Precipitates in the injected fluid could cause plugging of the walls in the injection well and destroy the permeability of the injection strata, thus destroying the usefulness of the we11. To prevent this, it may be necessary to pump the fluid into settling ponds or reactor-clarifiers to allow the precipitates to settle, and then filter and pump the clarified supernatant fluid into the we 11. Depending on the chemistry of the spent fluid, the $\mathrm{H}_{2} \mathrm{~S}$ would remain mostly in the fluid if the $\mathrm{pH}$ were high enough, or precipitate the sulfides of certain cations in the solution. If resources high in hydrogen sulfide were used, closed reactor-clarifier units rather than settling ponds may be required to suppress emission of the gas to the atmosphere.

\section{STEAM STACKING}

Steam stacking is a major source of $\mathrm{H}_{2} \mathrm{~S}$ emissions. This occurs (as described earlier) when emergency conditions require shutdown of the turbines and the plant steam is bypassed to the atmosphere. The increase in emissions caused by steam stacking at an abated plant can have a major effect on the total emissions of the development during the time of the release. An example to illustrate the effect of sudden steam stacking at The Geysers is described below. 
Total emission data for all units (1-11), taken from tables in Ref. 12, show for 7 mo in 1977:

(1) Average emissions without abatement $=865 \mathrm{~kg} / \mathrm{h}$

(2) Average emissions with $43.5 \%$ abatement $=489 \mathrm{~kg} / \mathrm{h}$

(3) Unit 11 emissions without abatement $=246 \mathrm{~kg} / \mathrm{h}$

(4) Unit 11 emissions with abatement $=57 \mathrm{~kg} / \mathrm{h}$

(5) Unit 11 emissions due to stacking $[(3)-(4)]=189 \mathrm{~kg} / \mathrm{h}$

From the above it can be shown that the increase in total emissions due to steam stacking Unit 11 would be $38.7 \%$, and the overall abatement would be reduced from $43.5 \%$ to $21.6 \%$. This is a significant change, and the effect on local ambient $\mathrm{H}_{2} \mathrm{~S}$ measurements could reveal violations of the California standard of $30 \mathrm{ppb}$ (for $1 \mathrm{~h}$ ) during the period of steam stacking.

Local Air Pollution Control Districts (APCD's) have set up tentative standards for total (absolute) amounts of $\mathrm{H}_{2} \mathrm{~S}$ emissions allowable based on the total electrical generating capacity of The Geysers development to the year 2000. The control requirements are covered in Section $V$.

Steam stacking at power plants using liquid-dominated resources will probably not be a problem of the same magnitude as it is at The Geysers. This is primarily because "shutting-in" a liquid resource well poses less threat of damaging the well since the fluid remains hot when flow is stopped. Also, if steam is not flashed off the fluid, the entire flow can bypass the plant and be injected back underground. There may be times of short duration when flashed-steam plants would resort to steam stacking during the period required to close down the producing wells. Flashed-steam plants that use upstream condenser-reboller systems for separating noncondensable gases along with $\mathrm{H}_{2} \mathrm{~S}$ removal can stack production steam without serious environmental hazard.

\section{HYDROGEN SULFIDE CONTROL REQUIREMENTS}

Concentrations of $\mathrm{H}_{2} \mathrm{~S}$ less than $14,000 \mu \mathrm{g} / \mathrm{m}^{3}\left(10,000 \mathrm{ppb}^{*}\right)$ are usually considered to be non-toxic ${ }^{26}$. However, the odor is readily detectable for most people at concentrations of $35 \mu \mathrm{g} / \mathrm{m}^{3}(25 \mathrm{ppb})^{27}$ and

$\overline{\text { parts per billion }}$ 
can be detected by some at concentrations as $10 \mathrm{w}$ as $10 \mu \mathrm{g} / \mathrm{m}^{3}(7 \mathrm{ppb})$. Exposure to these low concentrations has little or no significance to human health, 27 but may be beneficial to some plant species. Nevertheless, the low odor detection threshold provides the basis for public antagonism to $\mathrm{H}_{2} \mathrm{~S}$ emissions from geothermal development.

Control of $\mathrm{H}_{2} \mathrm{~S}$ emissions from geothermal energy processes is necessary to minimize the odor nuisance and to avoid exceeding ambient air quality standards. The degree of control needed depends on the emission limitations imposed by the standards. Emissions and ambient concentrations are related but not definitely correlatable. It is not possible now to calculate an allowable emission rate based strictly on an ambient standard at the property line or some other point. Although emission limits must be stipulated, they cannot be completely definitive until the geothermal industry has been more firmly characterized with improved operational and environmental control technology, adequate field measurements, and sophisticated modeling studies.

\section{MEASUREMENTS OF AMBIENT $\mathrm{H}_{2} S$ CONCENTRATIONS}

At The Geysers, several measurement programs have been undertaken to determine the frequency of occurrences of ambient $\mathrm{H}_{2} \mathrm{~S}$ concentrations higher than the state standard of $30 \mathrm{ppb}\left(42 \mu \mathrm{g} / \mathrm{m}^{3}\right)^{2}$. Several organizations have participated in collecting data using a variety of instruments and procedures. At the present time no extensive fixed site monitoring stations are operating. Lake County APCD, however, does operate two fixed site stations.

In 1976, SRI International established a data collection network of eight monitoring stations (Fig. 9) funded by PG\&E, Union 011 Company, Aminoil U.S.A., and Thermogenics, Incorporated. Each of the monitoring sites was equipped to measure $\mathrm{H}_{2} \mathrm{~S}$ concentration, wind speed and direction, temperature, dew point, and precipitation. All data was collected automatically and transmitted to a central station for subsequent analysis. 


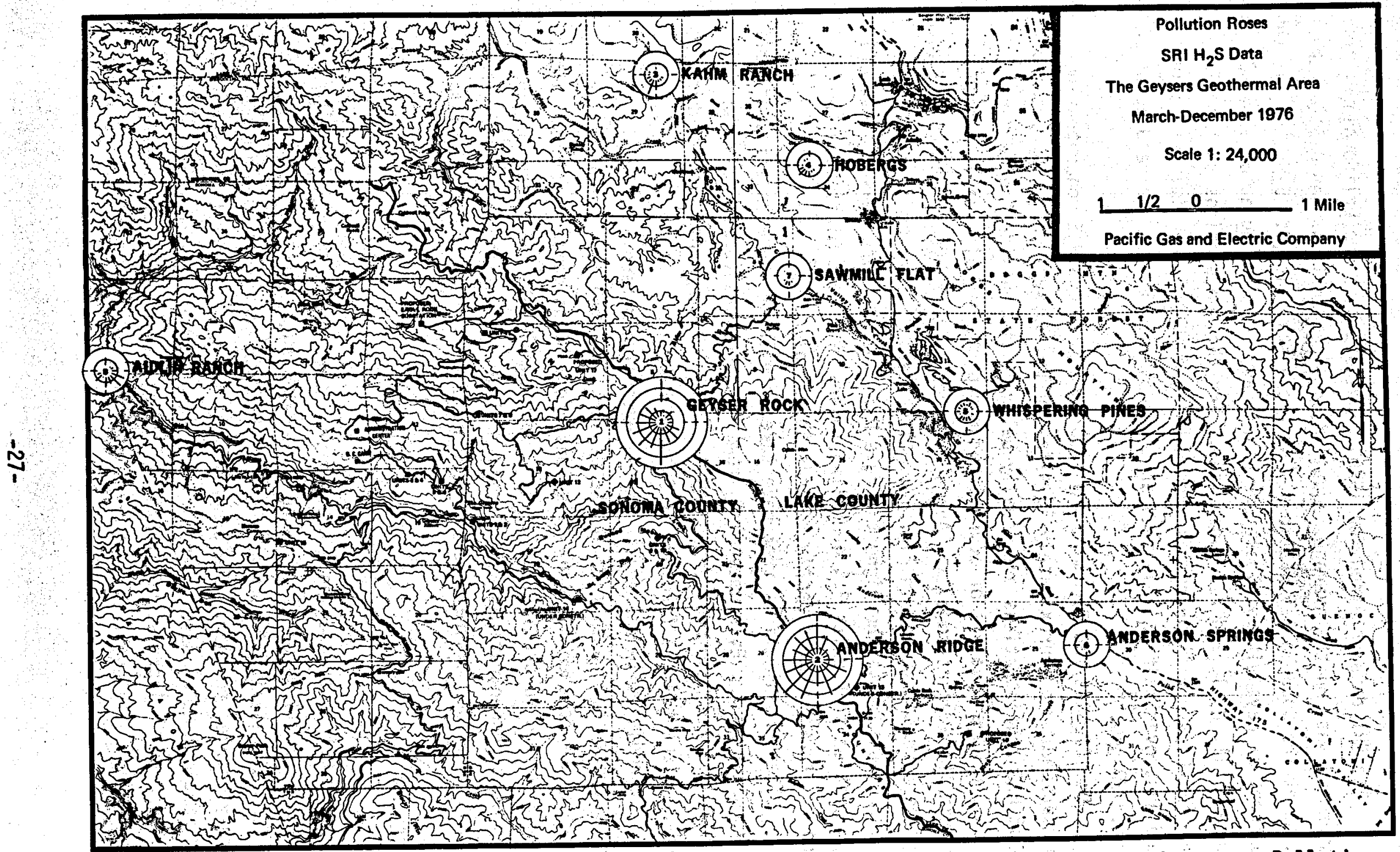

FIG. 9. Locations of $\mathrm{H}_{2} \mathrm{~S}$ pollution roses and monitoring stations in the SRI network at The Geysers. Pollution roses are average concentrations in $\mathrm{ppb}$ associated with winds in a given direction. Data was presented by R. Ruff at the LLL geothermal workshop (Sept. 27-28, 1977) on air quality at The Geysers. 
The SRI data obtained for $1976^{28}$ indicate that the California state standard was, on the average, equalled or exceeded less than $0.5 \%$ of the time at the Cobb Valley stations. At these stations $(3,4,5,6$, and 7$)$, the percent of days with at least one hourly average reading at or above $30 \mathrm{ppb}$ were $6,11,8,1$, and 7 respectively. For the two stations on the ridge (1 and 2) the state standard was exceeded 7 and $10 \%$ of the time respectively, and just over half the days had at least one hourly average reading at or above $30 \mathrm{ppb} .^{23}$

Pacific Gas and Electric has also made numerous $\mathrm{H}_{2} \mathrm{~S}$ concentration measurements at approximately 30 sites in The Geysers area. Data indicate that $\mathrm{H}_{2} \mathrm{~S}$ concentrations are usually below $30 \mathrm{ppb}$ outside The Geysers area. However, values of several hundred parts per billion were found within The Geysers complex. Average values of these measurements are shown by the circled figures in Fig. 10. Altshuler's ${ }^{29}$ summary of the PG\&E measurements shows the highest single $\mathrm{H}_{2} \mathrm{~S}$ concentration measured was 870 ppb just east of Units $3 \& 4$ cooling towers when west winds blew the cooling-tower plume directly towards the sampler.

Other organizations that have taken similar measurements include the Lake County APCD, Evironmental Systems and Services (ES\&S), and the California Air Resources Board (ARB). Their measurements have confirmed and supplemented the findings of SRI and PG\&E.

In addition to $\mathrm{H}_{2} \mathrm{~S}$ measurements, extensive meterorological measurements have been made at the Geysers to establish a correlation between the geothermal plant emissions and ambient concentrations. These data may lead to predictions of when odor complaints will occur or when pollutant concentrations will exceed ambient air quality criteria. The extent of these measurements has been reported by Rosen and Molenkamp. ${ }^{23}$

MODELING

The DOE is sponsoring a program for Atmospheric Studies in Complex Terrain (ASCOT) which is designed to develop the technology needed to perform air quality impact assessments for new energy sources in areas of highly complex terrain. The program will integrate theoretical research, mathematical model development, field measurements, and physical model experiments to improve fundamental knowledge and develop techniques for predicting pollutant transport and dispersion in terrain-dominated flows. 


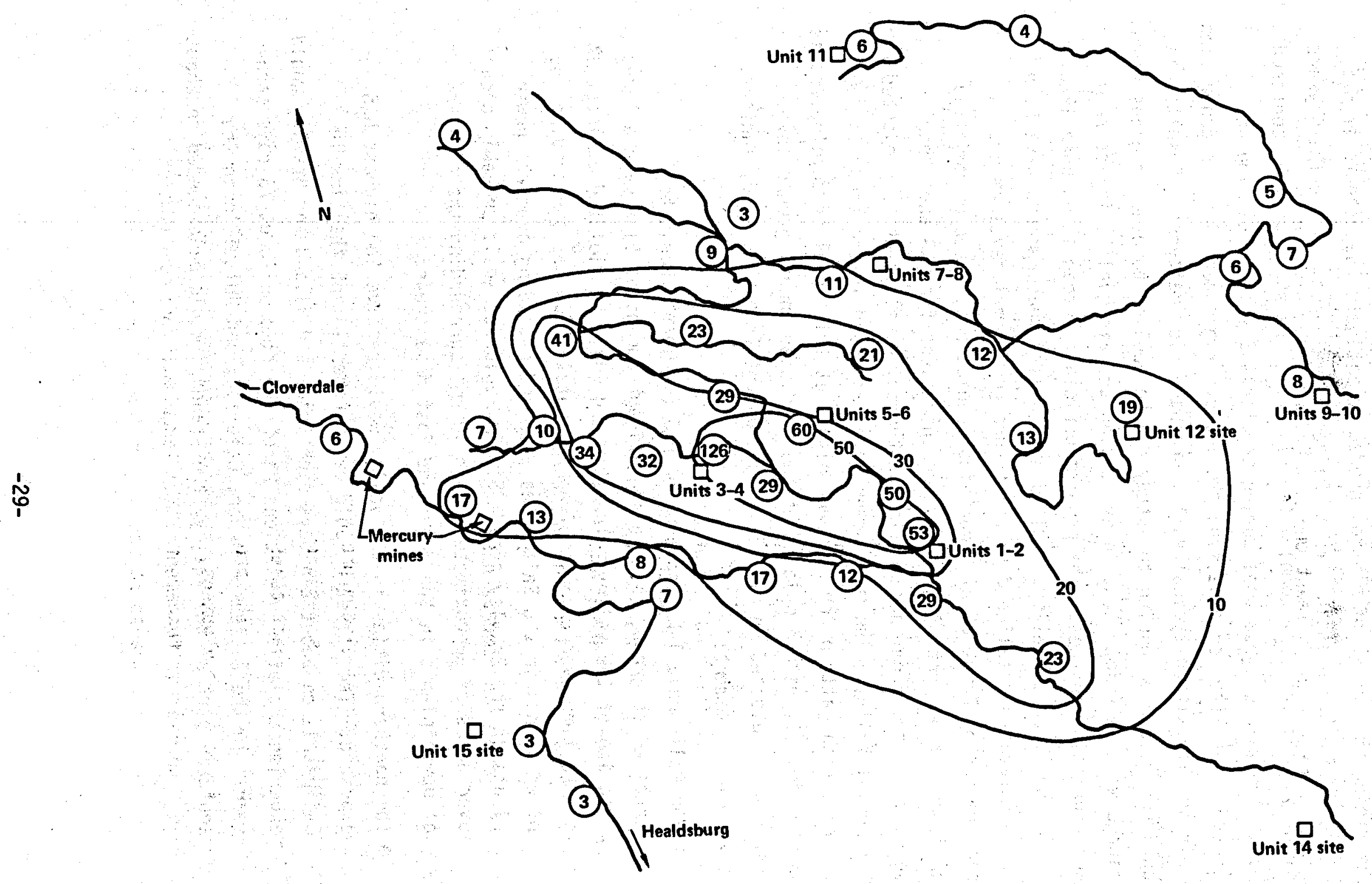

FIG. 10. Average $\mathrm{H}_{2} \mathrm{~S}$ concentrations (ppb) measured by PG\&E at The Geysers power plant. Data taken from Ref. 2. 
Although not a control technology per se, the program will aid in. determining the degree of control needed to mitigate the effects of $\mathrm{H}_{2} \mathrm{~S}$ releases and other emissions from the geothermal area. Since The Geysers eminently qualifies as a complex terrain area, the study will be centered there. The main program goal during the first $3 y$ is to develop an improved capability for assessing the impact of geothermal power generation on air quality within typical valley drainage flow patterns. Results and techniques developed during the study can be applied to other regions where drainage winds are important in evaluating the air quality impact from power generating sources. The program officially began in October 1978.

In the Imperial Valley, limited air quality measurements have been made to establish baseline data for future geothermal development. A recent report by Ermak et al. ${ }^{3}$ contains predictions, based on modeling techniques, of ambient air quality concentrations for $\mathrm{H}_{2} \mathrm{~S}$ and other gaseous emissions from uncontrolled geothermal development as projected for the Imperial valley. The main power level assessed in the study is 3000 MW. The siting pattern for 30 power plants at this level of development is shown in Fig. 11, with isopleths of the predicted annual ground level concentrations plotted in Fig. 12. Conclusions from this study indicate that with no abatement: ${ }^{3}$

- The California l-h standard for $\mathrm{H}_{2} \mathrm{~S}\left(42 \mu \mathrm{g} / \mathrm{m}^{3}\right)$ would be exceeded at ground level a significant amount of time over a large fraction of the valley. The standard would be violated at least $1 \%$ of the time over an area of approximately $1500 \mathrm{~km}^{2}$ surrounding the power plants in the Salton Sea area and extending over the power plants in the Brawley area. Similar episodes would probably occur over areas of approximately 5 to $10 \mathrm{~km}^{2}$ surrounding the clusters of power plants in the Heber and East Mesa areas.

- The northern cities in the valley would receive the highest $\mathrm{H}_{2} \mathrm{~S}$ exposure. The standard would be exceeded $10 \%$ of the time in Calipatria on about 245 days each year, and Niland and Brawley would experience similar violations $2 \%$ of the time on about 73 days each year. In the cities of Heber, Calexico, and Holtville in the southern part of the valley, the standard would be exceeded on about 
14 days each year, and in Mexicali, Mexico, a couple of days each year. No breaches of the $\mathrm{H}_{2} \mathrm{~S}$ standard are predicted for the central valley cities of El Centro and Imperial.

- Model calculations for a single power plant indicate that the $\mathrm{H}_{2} \mathrm{~S}$ standard is not exceeded beyond a distance of about $1 \mathrm{~km}$ when the emission rate is less than $0.8 \mathrm{~g} / \mathrm{s}$.

- The model predicts that nearly the entire valley--approximately $5000 \mathrm{~km}^{2}$-would experience concentration levels in excess of $10 \mu \mathrm{g} / \mathrm{m}^{3}$ (the average odor threshold) at least $1 \%$ of the time.

It can be seen from the foregoing that the occurrences of $\mathrm{H}_{2} \mathrm{~S}$ concentrations above the state standard at The Geysers and predicted to occur in the Imperial Valley, demand that $\mathrm{H}_{2} \mathrm{~S}$ emissions be abated to levels that prevent air quality violations. 


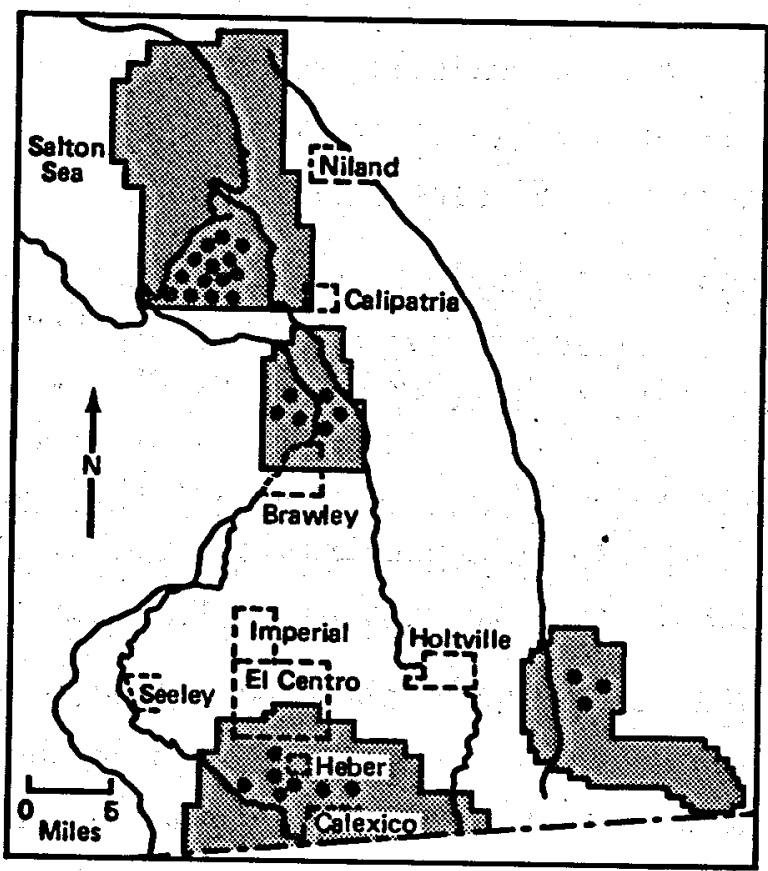

FIG. 11. Siting pattern for 30 power plant units in the $3000 \mathrm{MN}$ scenario.

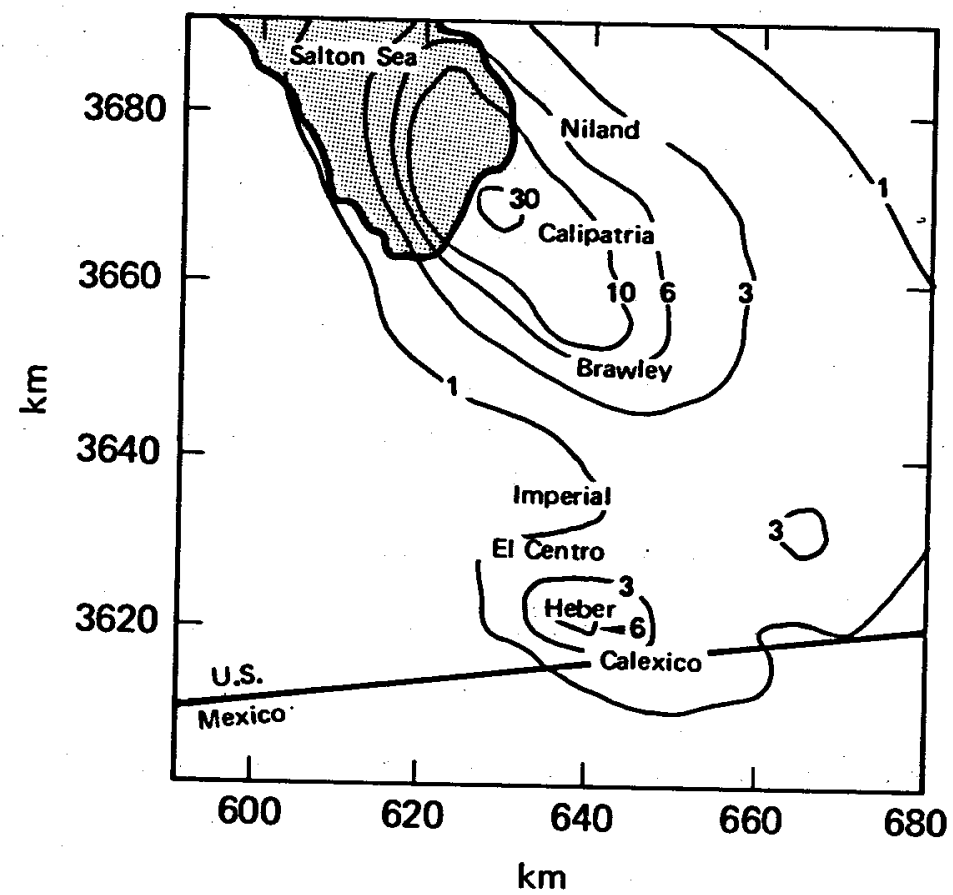

FIG. 12. Isopleth plot of the annual average ground leve $1 \mathrm{H}_{2} \mathrm{~S}$ concentration in $\mu \mathrm{g} / \mathrm{m}^{3}$. 
The existing ambient air standard for California is $0.03 \mathrm{ppm}$ $\left(42 \mu \mathrm{g} / \mathrm{m}^{3}\right.$ ) for a Time Weighted Average (TWA) of $1 \mathrm{~h}$, not to be exceeded more than one time each year. A similar standard exists for New Mexico at $0.003 \mathrm{ppm}$. The New Mexico standard is below the olfactory detection threshold for most humans, and below the detection 1 imits for most field analytical instruments. At these concentrations there are few, if any, adverse heaith effects. Hydrogen suifide concentrations in the facility work environment (i.e. in or near the power plant) may be of greater health significance. Table 71 ists fairly recent suggested permissible concentrations of $\mathrm{H}_{2} \mathrm{~S}$ in workroom air.

TABLE 7. Suggested permissible concentrations of $\mathrm{H}_{2} \mathrm{~S}$ workroom air.

Organization Permissible Concentrations

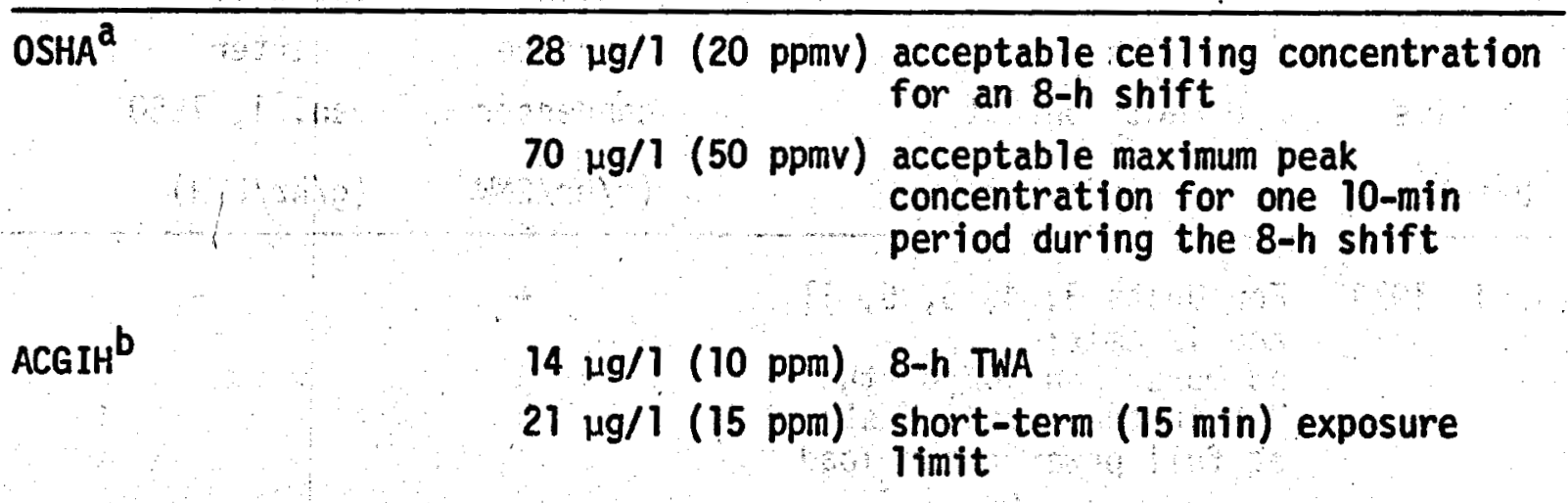

accupational Safety and Health Administration, U. S. Department of Labor. Ref. 28 (1974).

bamerican Conference of Governmental Industrial Hygienists. Ref. 24 (1975). 
Proposed State of California regulations are discussed in a memorandum by Moyer and a paper by Joyce and Fontes (Appendix $D$ ).

To illustrate the regulatory requirements of a local authority, a regulation of the North Sonoma County Air Pollution Control District (NSCAPCD) is given:

Rule 455 - a. No person shall discharge into the atmosphere from any geothermal operation sulfur compounds calculated as sulfur dioxide $\left(\mathrm{SO}_{2}\right)$, in excess of $1,000 \mathrm{ppm}$.

b. No person shall discharge $\mathrm{H}_{2} \mathrm{~S}$ into the atmosphere at a rate which exceeds those set forth in Tables 8 and 9.

c. A summary of the data required to determine compliance with applicable provisions of this role shall be submitted to the Control Officer. This sumary shall be presented in the manner, frequency and form as prescribed by the Control offier.

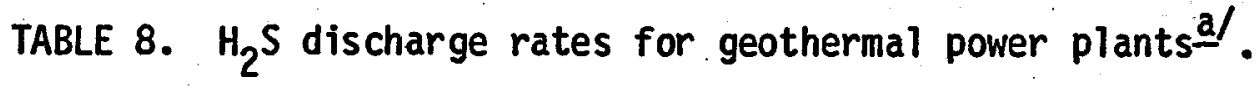

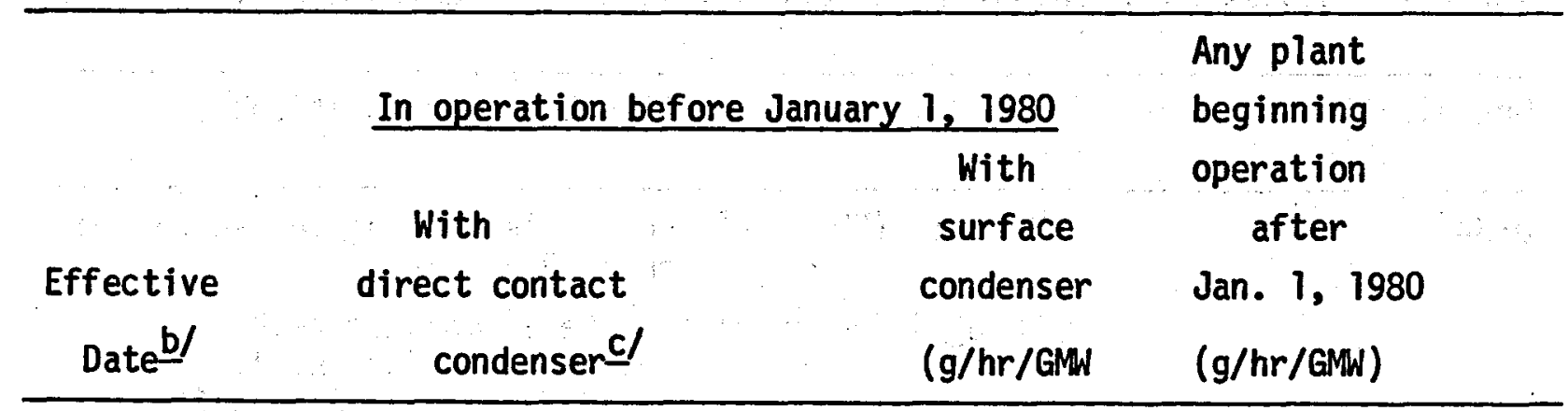

Jan. 1, 1979 For Units $3,4,5,6,11$, and 12 emit:

no more than $10 \%$ of the

$\mathrm{H}_{2} \mathrm{~S}$ in the supplied steam

at full power plant load

$200 \mathrm{~g} / \mathrm{hr} /$ GMW average

using allocation methodh/

Jan. 1, 1980

i/

100

100

Jan. 1, 1982

Units $3-6,1]$, and 12:
$200 \mathrm{~g} / \mathrm{hr} / \mathrm{GMW}$ :

Jan. I, 1985

i/

Jan. 1, 1990

$100 \mathrm{~g} / \mathrm{hr} / \mathrm{GMW} /$

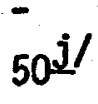

Jan. 1, 2000 
TABLE 9. $\mathrm{H}_{2} \mathrm{~S}$ discharge rates from steam transmission lines ${ }^{\mathrm{a}, \mathrm{g}}$

\begin{tabular}{|c|c|c|c|c|}
\hline $\begin{array}{l}\text { Effective } \\
\text { date }- \text { / }\end{array}$ & $\begin{array}{l}\text { Existing or permitted } \\
\text { systems as of } \\
\text { June 1, } 1978\end{array}$ & New systems & $\begin{array}{l}\text { 0ther geoth } \\
\text { Wel1 drilling, } \\
\text { reworking, } \\
\text { and testing } \\
(\mathrm{kg} / \mathrm{hr} / \text { well) }\end{array}$ & $\begin{array}{l}\text { sources } \\
\text { Small source } \\
\text { emissions } \\
(\mathrm{kg} / \mathrm{hr} / \text { source })\end{array}$ \\
\hline June 1, 1979 & $\begin{array}{l}\text { Upon an unshceduled outage } \\
\text { an operator shall within } \\
4 \mathrm{hr} \text { or less reduce } \mathrm{H}_{2} \mathrm{~S} \\
\text { emissions: (a) by } 90 \% \text { or } \\
\text { more for dual units, or } \\
\text { (b) by } 50 \% \text { or more for } \\
\text { single units or when both } \\
\text { units of a dual unit } \\
\text { system have a simultaneous } \\
\text { outage, or (c) to not more } \\
\text { than } 15 \mathrm{~kg} / \mathrm{hr} \text {. For sched- } \\
\text { uled outage the same emis- } \\
\text { sion standards shall be } \\
\text { met within } 1 \mathrm{hr} \text { or less. }\end{array}$ & $\begin{array}{l}\text { Upon an unscheduled outage } \\
\text { the operator shall within } \\
4 \mathrm{hr} \text { or less reduce } \mathrm{H} S \\
\text { emissions: (a) by } 90 \%{ }^{2} \text { or } \\
\text { more, or (b) by } 50 \% \text { or } \\
\text { more when both units of a } \\
\text { dual unit system have a } \\
\text { simultaneous outage, or } \\
\text { (c) to not more than } 15 \\
\mathrm{~kg} / \mathrm{hr} \text {. For a scheduled } \\
\text { outage the same emission } \\
\text { standards shall be met } \\
\text { within } 1 \mathrm{hr} \text { or less. }\end{array}$ & 5e/ & - \\
\hline Jan. 1, 1980 & d/ & d/ & $2.1 \mathrm{e} /$ & $2.0 \div$ \\
\hline Jan 1, 1982 & $\begin{array}{l}\text { To be prgmulgated by } \\
\text { A.P.C.0. }\end{array}$ & $\begin{array}{l}\text { To be prgmulgated by } \\
\text { A.P.C.0. }\end{array}$ & - & $\begin{array}{l}1.0^{-17} \\
0.5^{f \prime}\end{array}$ \\
\hline Jan. 1,1990 & - & - & 7 & - \\
\hline Jan. 1,2000 & - & - & - & - \\
\hline
\end{tabular}


af All geothermal power plants, including new construction, must comply with future emission rate reductions as they become effective.

b/ $\mathrm{H}_{2} \mathrm{~S}$ emission limitations for each category of emission source will become effective henceforth on the date indicated at the left of the Table.

c/ "g/hr/GM" shall equal "grams per hour per gross megawatt." The rates of emission may be equaled but not exceeded. Compliance shall be verified by the source testing method approved by the District for the applicable emission source.

d/ The Air Pollution Control Officer shall after proper notice and public hearing promulgate on or before January 1, 1980, the emission standards commencing January 1, 1982, based upon a review of available control technology, air quality, emissions, and extent of development.

ef Individual well emissions shall be 1 imited to $5 \mathrm{~kg} / \mathrm{hr} / \mathrm{well}(2.5$ $\mathrm{kg} / \mathrm{hr} /$ well after January 1,1980 ) unless a higher rate was determined by new source review or unless applicant provides data which subsequently can justify a redetermination of the emission rate by the Air Pollution Control officer.

f/ Small sources include continuous well and pipeline bleeds. Allowable emissions are those shown in Table 9 unless otherwise determined by the Air Pollution Control Officer.

g/ "Reduce $\mathrm{H}_{2} \mathrm{~S}$ by $50 \%$ " shall mean emit no more than $50 \%$ of the $\mathrm{H}_{2} \mathrm{~S}$ normally found in the supplied steam at full power plant load. "Dual units" shall refer to those steam transmission lines associated with two power plant units located in the same building and therefore such associated steam transmission lines shall be considered as one source.

h/ Allocation method: If less than $200 \mathrm{~g} / \mathrm{hr} / \mathrm{GMW}$ is attained at one power plant unit, the reduction (in grams $\mathrm{H}_{2} \mathrm{~S}$ per hour) can be credited to another power plant unit or apportioned to other power plant units.

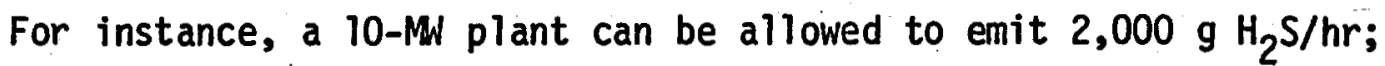
but if a credit of $500 \mathrm{~g} \mathrm{H}_{2} \mathrm{~S}$ were allocated, it could emit $2,500 \mathrm{~g}$ 
$\mathrm{H}_{2} \mathrm{~S}$ per hour or $250 \mathrm{~g} / \mathrm{hr} / \mathrm{GMW}$. The allocation should be modified no more than quarterly and only if needed based on new data. (The major purpose of the allocation method is for individual power plant unit compliance verification and credit for greater $\mathrm{H}_{2} \mathrm{~S}$ reduction than 90\%.)

i/ For Units $1,2,7,8,9$ and 10, the Air Pollution Control officer shall after proper notice and public hearing promulgate on or before January 1, 1980, the emission standards commencing January 1, 1982, and January 1, 1985, based upon a review of available technology, air quality, emissions, and extent of development.

j/ The Air Pollution Control Officer, 1 year prior to each achievement date, shal1, after review of air quality, extent of development, emissions, and available control technology, promulgate a new source emission standard if different than presently set forth after proper notice and public hearing. 
There are certain technical requirements desirable for an environmental control technology to be efficient in $\mathrm{H}_{2} \mathrm{~S}$ abatement:

- The process must be economical so that costs to the producer (and thus to the consumer) are not prohibitive.

- An abatement process should not increase hazards to plant workers or to the environment. Some processes require the use of hazardous chemicals such as hydrogen peroxide $\left(\mathrm{H}_{2} \mathrm{O}_{2}\right)$ and concentrated sodium hydroxide $(\mathrm{NaOH})$. These materials must be transported to the plant site and in so doing increase the opportunities for dangerous spills. Storage of chemicals may also present a hazard. Processes that regenerate the needed chemicals are preferred to those that require a continuous new supply.

- The process should not create or add to corrosion problems that may already exist. Corrosive situations markedly increase maintenance costs and operational difficulties, not only to the abatement equipment, but also to the power plant.

- The system should have a rapid response time to variations in $\mathrm{H}_{2} \mathrm{~S}$ content of the resource. Chemical systems should not be 1 imited by slow kinetics in their reactions.

- The process should not cause excess reduced efficiencies in power conversion or other negative impacts such as excessive pressure or temperature reductions in the resource supply.

- Certain abatement processes are extremely dependent on the partitioning of $\mathrm{H}_{2} \mathrm{~S}$ in the condenser. The $\mathrm{pH}$ of the condenser fluid must be at an optimum value for the process in use.

Processes must minimize the production of excessive solid wastes which may cause plugging of lines. These wastes also create a disposal problem and must be trucked to dumpsites.

- The process should not add to environmental problems because of chemicals used for abatement being emitted by the cooling tower drift. 


\section{HYDROGEN SULFIDE CONTROL TECHNOLOGIES}

The state of the art experience for the environmental control of $\mathrm{H}_{2} \mathrm{~S}$ from geothermal emissions has been gained by experimental techniques being developed and put into practice at The Geysers. The greatest efforts are being directed at the abatement of $\mathrm{H}_{2} \mathrm{~S}$ emissions from the major release points: the condenser vent gas ejection systems and the cooling towers. Any successful abatement technologies developed at The Geysers should be directly applicable to $\mathrm{H}_{2} \mathrm{~S}$ removal from flashed steam derived from liquid-dominated resources.

Some of the technologies for the control of $\mathrm{H}_{2} \mathrm{~S}$ in the geothermal industry have been adapted from other industrial processes such as the removal of sulfur from coal gas. Most of these are not suitable for geothermal application because of slow kinetics, high cost, or the chemical form of the sulfur waste product. Table 10 lists many of the commercial processes available. The systems that react chemically with $\mathrm{H}_{2} \mathrm{~S}$, such as the Stretford process, seem to be better candidates for geothermal application than systems that depend on physical absorption phenomena. The end waste product of physical absorption processes is usually $\mathrm{H}_{2} \mathrm{~S}$ which requires final clean-up by a process such as stretford.

\section{HYDROGEN SULFIDE ABATEMENT DURING WELL DRILLING AND TESTING}

Abatement of $\mathrm{H}_{2} \mathrm{~S}$ during well drilling and testing is routinely practiced at the Geysers. A system of $\mathrm{H}_{2} \mathrm{~S}$ abatement during well drilling using $\mathrm{H}_{2} \mathrm{O}_{2}$ and $\mathrm{NaOH}$ is used effectively at the Geysers and has been described by Castrantas et a1. 32 A schematic taken from Ref. 32 is shown as Fig. 13. In this $\mathrm{H}_{2} \mathrm{~S}$ abatement process, $\mathrm{NaOH}$ and $\mathrm{H}_{2} \mathrm{O}_{2}$ are spray injected into the steam as it leaves the wellhead and enters the Blooie line (exhaust line from the air drilling manifold). This procedure is used only during the air drilling phase of well completion which lasts for about $16 \mathrm{~d}$. 
TABLE 10. Sulfur removal systems ${ }^{a}$

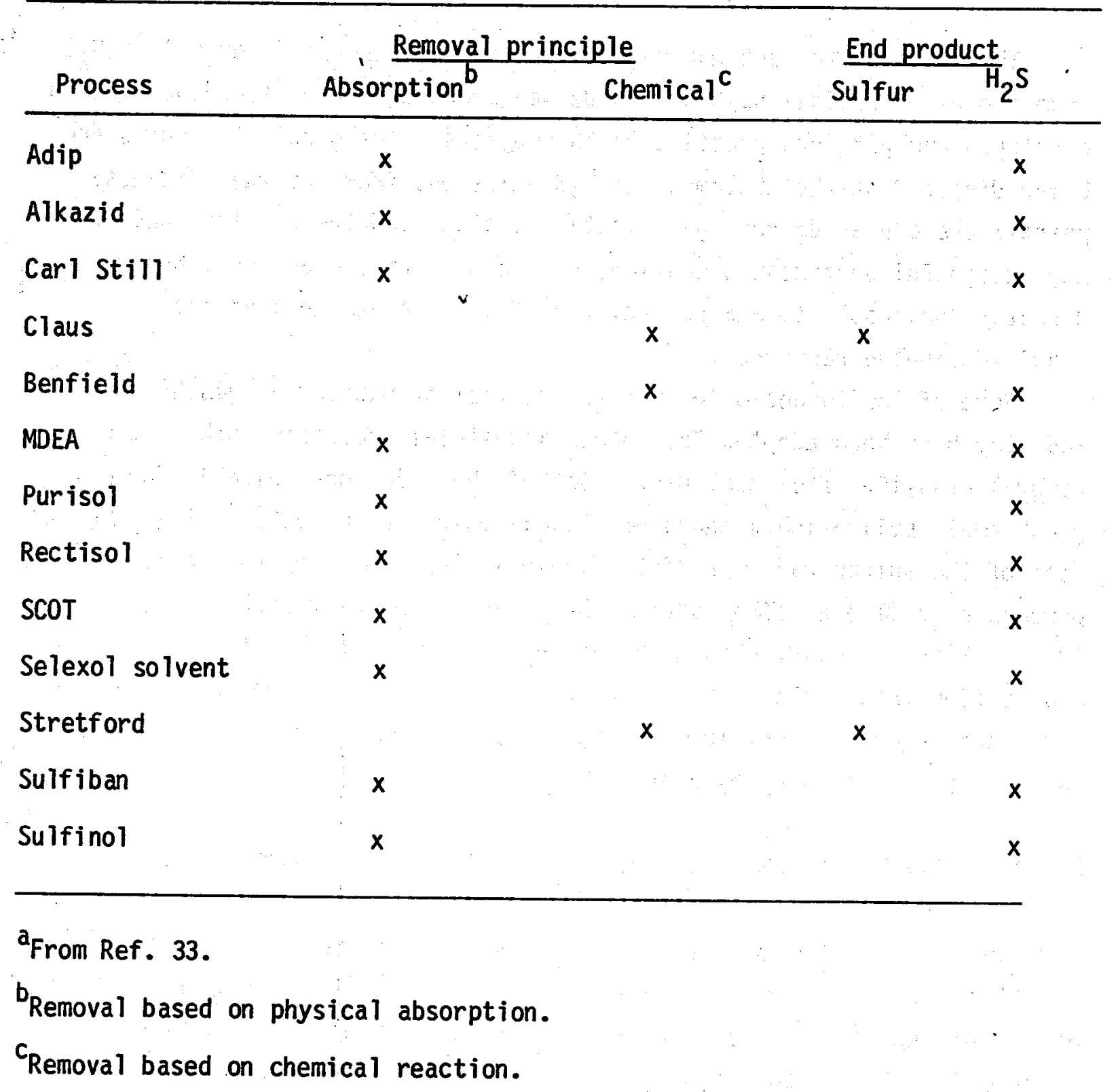




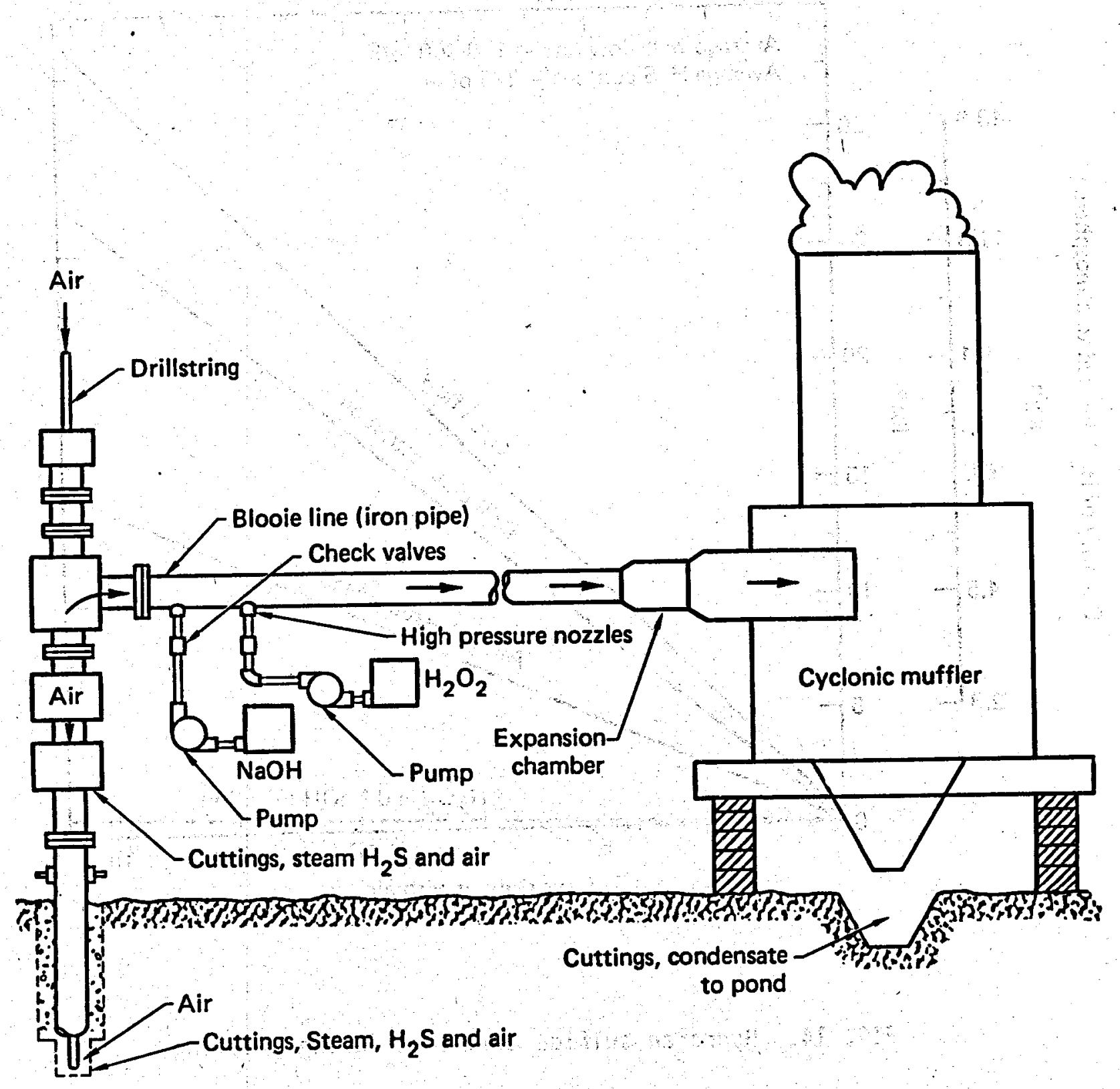

FIG. 13. A typical geothermal drilling/muffler setup. 


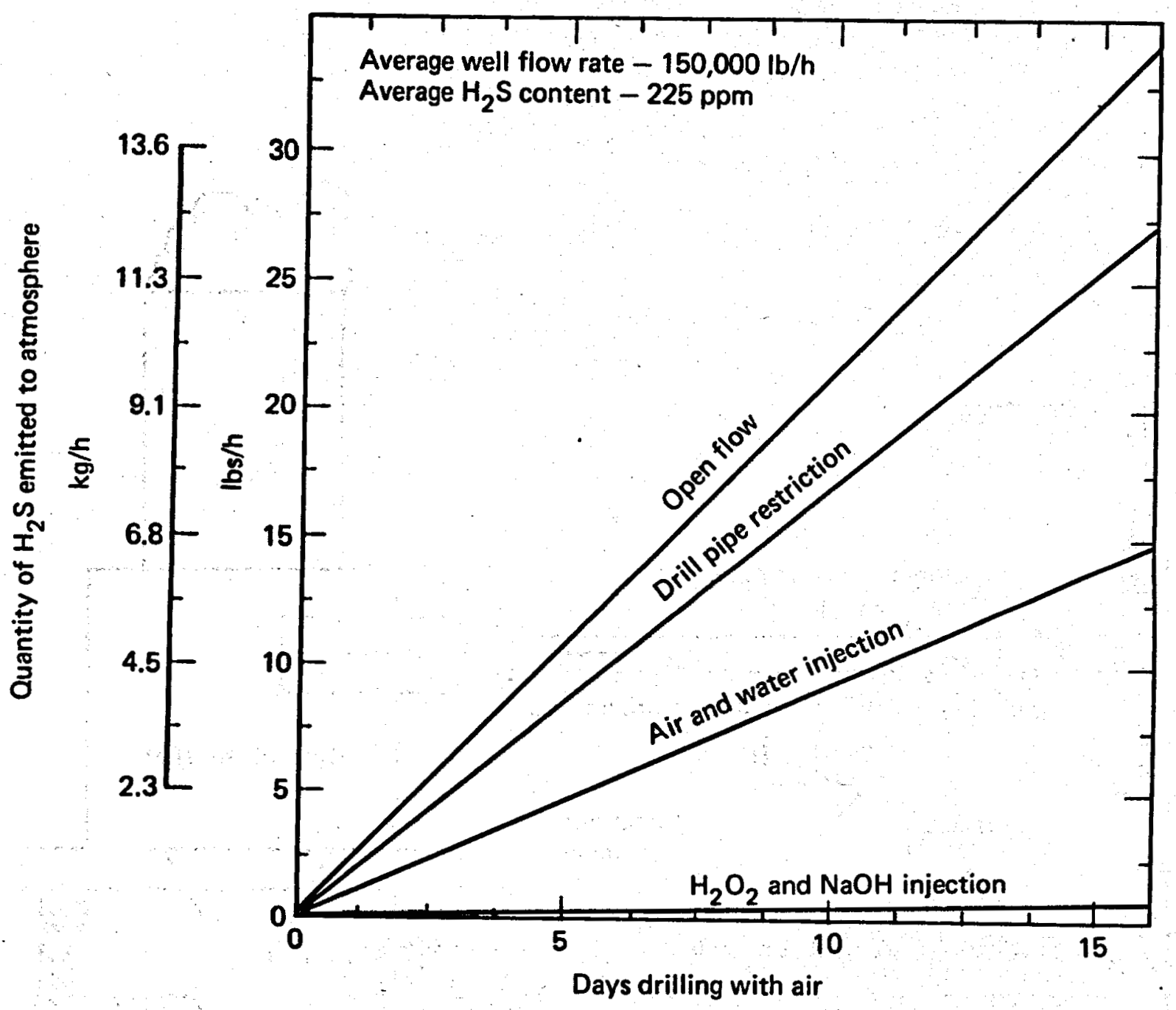

FIG. 14. Hydrogen sulfide emissions during drilling. 
Abatement is achieved by absorption of the $\mathrm{H}_{2} \mathrm{~S}$ into the $\mathrm{NaOH}$ spray (which is injected ahead of the $\mathrm{H}_{2} \mathrm{O}_{2}$ ) to form bisulfide $\left(\mathrm{HS}^{-}\right.$) and sulfide $S^{-2}$ ) ions:

$$
\begin{aligned}
& \mathrm{H}_{2} \mathrm{~S}+\mathrm{OH}^{-} \rightarrow \mathrm{HS}^{-}+\mathrm{H}_{2} \mathrm{O}, \\
& \mathrm{H}_{2} \mathrm{~S}+2 \mathrm{OH}^{-}+\mathrm{S}^{-2}+2 \mathrm{H}_{2} \mathrm{O} .
\end{aligned}
$$

The intermediate ions are then oxidized by $\mathrm{H}_{2} \mathrm{O}_{2}$ to form bisulfate $\left(\mathrm{HSO}_{4}{ }^{-}\right)$and sulfate $\left(\mathrm{SO}_{4}{ }^{-2}\right)$ ions:

$$
\begin{aligned}
& \mathrm{HS}^{-}+4 \mathrm{H}_{2} \mathrm{O}_{2}+\mathrm{HSO}_{4}^{-}+4 \mathrm{H}_{2} \mathrm{O} \\
& \mathrm{S}^{-2}+4 \mathrm{H}_{2} \mathrm{O}_{2}+\mathrm{SO}_{4}^{-2}+4 \mathrm{H}_{2} \mathrm{O}
\end{aligned}
$$

It is important that $\mathrm{NaOH}$ be used so that $\mathrm{HSO}_{4}^{-}$and $\mathrm{SO}_{4}^{-}$ will be formed, because these products will not revert to $\mathrm{H}_{2} \mathrm{~S}$ if the condensate pond should become acid at a later date.

The process has been effectively used during air drilling at steam flows up to $68,200 \mathrm{~kg} / \mathrm{h}(150,000 \mathrm{lb} / \mathrm{h})$ with up to $98 \%$ abatement of $\mathrm{H}_{2} \mathrm{~S}$. It is effective over a wide range of $\mathrm{H}_{2} \mathrm{~S}$ concentrations (several hundred parts per million ) in the steam. Figure 14 indicates the efficiency of the process (Ref. 29).

The system has proved very reliable and is being used by Union $0 i 1$ Company regularly. It has been assembled as a portable skid unit to be used wherever needed.

It has been estimated that the cost to achieve $83 \%$ to $98 \%$ abatement during the final 16 d of driling is $\$ 6,800$ to $\$ 9,000.32$

UPSTREAM ABATEMENT TECHNOLOGY FOR POWER PLANT EMISSIONS

The release of $\mathrm{H}_{2} \mathrm{~S}$ from power plants is of major concern because about $90 \%$ of the total releases can be attributed to the power conversion process itself. Depending on the conversion process, most of the emissions occur either from the cooling tower or from the noncondensable gas ejector system.

Figures 15 and 16 show that some of the same abatement technologies can be applied either upstream or downstream of the power plant. 


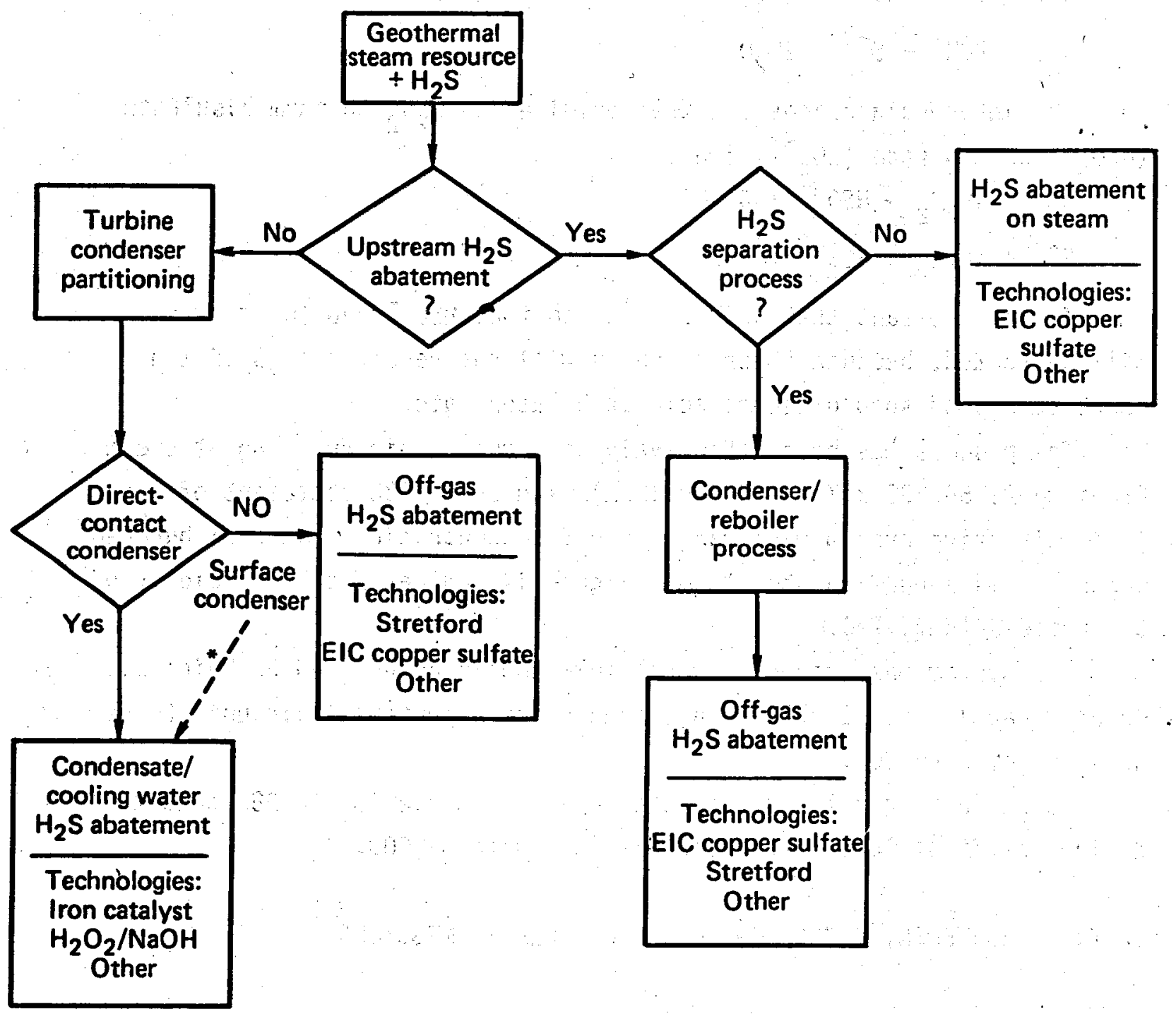

FIG. 15. A logic diagram to indicate some abatement technologies for control of $\mathrm{H}_{2} \mathrm{~S}$ emissions from geothermal steam plants, and where they may be applied. *Secondary treatment of the condensate may be required. 


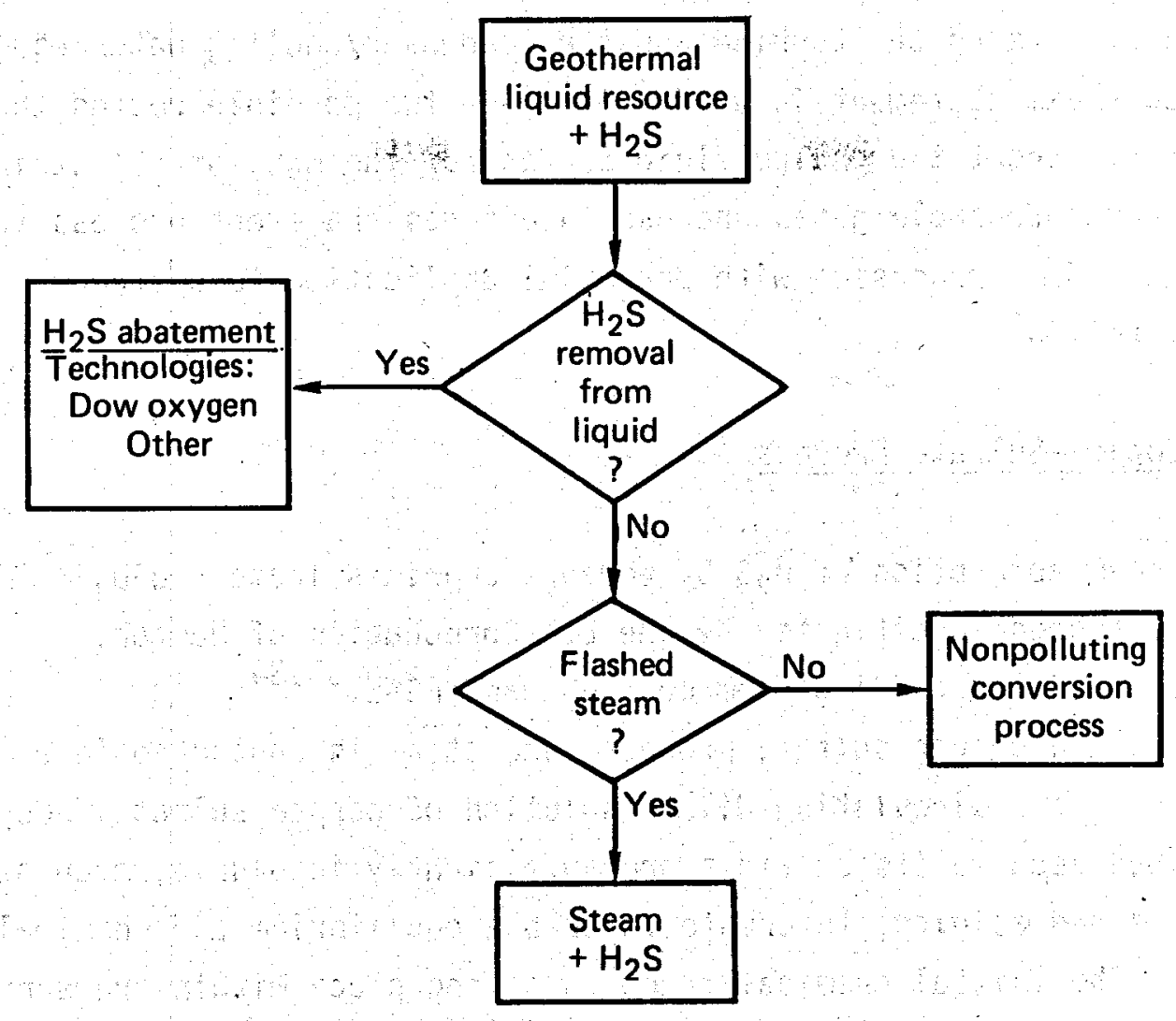

FIG. 16. Logic diagram to indicate some abatement technologies for control of $\mathrm{H}_{2} \mathrm{~S}$ emissions from geothermal liquid resource plants. When steam is produced by flashing the resource fluid, the same abatement scheme shown in Fig. 15 can be used.

Upstream abatement has a main advantage that if the power plant goes down due to upset conditions, the steam can be stacked from impunity because the released steam is low in $\mathrm{H}_{2} \mathrm{~S}$.

A second advantage of upstream abatement is that less costly direct-contact condensers can be used instead of surface condensers. The use of direct-contact condensers would allow the application of an efficient secondary treatment system on the cooling water/condensate for removal of residual $\mathrm{H}_{2} \mathrm{~S}$ if required. Also, the on-line availability of the secondary treatment system could serve as a backup abatement system 
when the primary upstream system is upset or down for maintenance An additional benefit of upstream removal of $\mathrm{H}_{2} \mathrm{~S}$ is the reduction of corrosion effects on the turbine and the condenser/cooling water equipment.

If upstream abatement is used, there are two possible routes that can be taken: (1) treat the entire fluid to destroy the $\mathrm{H}_{2} \mathrm{~S}$, or (2) strip the fluid of noncondensable gases and use an off-gas abatement process to remove $\mathrm{H}_{2} \mathrm{~S}$. Some processes with potential application to upstream abatement follow.

\section{The EIC Copper Sulfate Process}

Upstream absorption of $\mathrm{H}_{2} \mathrm{~S}$ by aqueous cupric sulfate $\left(\mathrm{CuSO}_{4}\right)$ solution has been investigated by the EIC Corporation of Newton, Massachusetts, with funding from both DOE and PG\&E. 33,34 .

In the EIC copper sulfate process, the steam is contacted in a scrubber with a recirculating dilute solution of copper sulfate. Copper was selected because its sulfides are sufficiently insoluble, even at high temperature and acidity, to create favorable equilibrium and chemical kinetics. The initial chemical reaction taking place within the scrubber is approximately:

$\mathrm{H}_{2} \mathrm{~S}$ (in steam) $+\mathrm{CuSO}_{4}$ (aqueous) $\rightarrow \mathrm{CuS}$ (ppt) $+\mathrm{H}_{2} \mathrm{SO}_{4}$ (aqueous). With extended residence time of the precipitated copper sulfide (CuS), sulfur is formed by the following reaction:

$2 \mathrm{CuS} \rightarrow \mathrm{Cu}_{2} \mathrm{~S}+\mathrm{S}$.

A simplified flow diagram of the scrubbing process is shown in Fig. 17. The scrubber is a simple tray-type tower, although Venturi scrubbers and packed towers have also been evaluated. Geothermal steam passes through the scrubber where $\mathrm{H}_{2} \mathrm{~S}$ and other pollutants $\left(\mathrm{NH}_{3}\right.$ and $\left.\mathrm{B}\right)$ are removed. The scrubber solution containing insoluble precipitates is partly recycled to the scrubber, the remainder sent to the regeneration system. Ammonia is added to the scrubbing solution to maintain the $\mathrm{pH}$ within the range of 1.2 to $1.5 .^{30}$ The precipitate in the recycled slurry is a mixture of cuprous sulfide (chalcocite, $\mathrm{Cu}_{2} \mathrm{~S}$ ), cupric sulfide (covellite, CuS), and 
elemental sulfur. The cuprous sulfide fraction has a composition of from $\mathrm{Cu}_{1.8} \mathrm{~s}$ to $\mathrm{Cu}_{1.95} \mathrm{~s}^{33}$

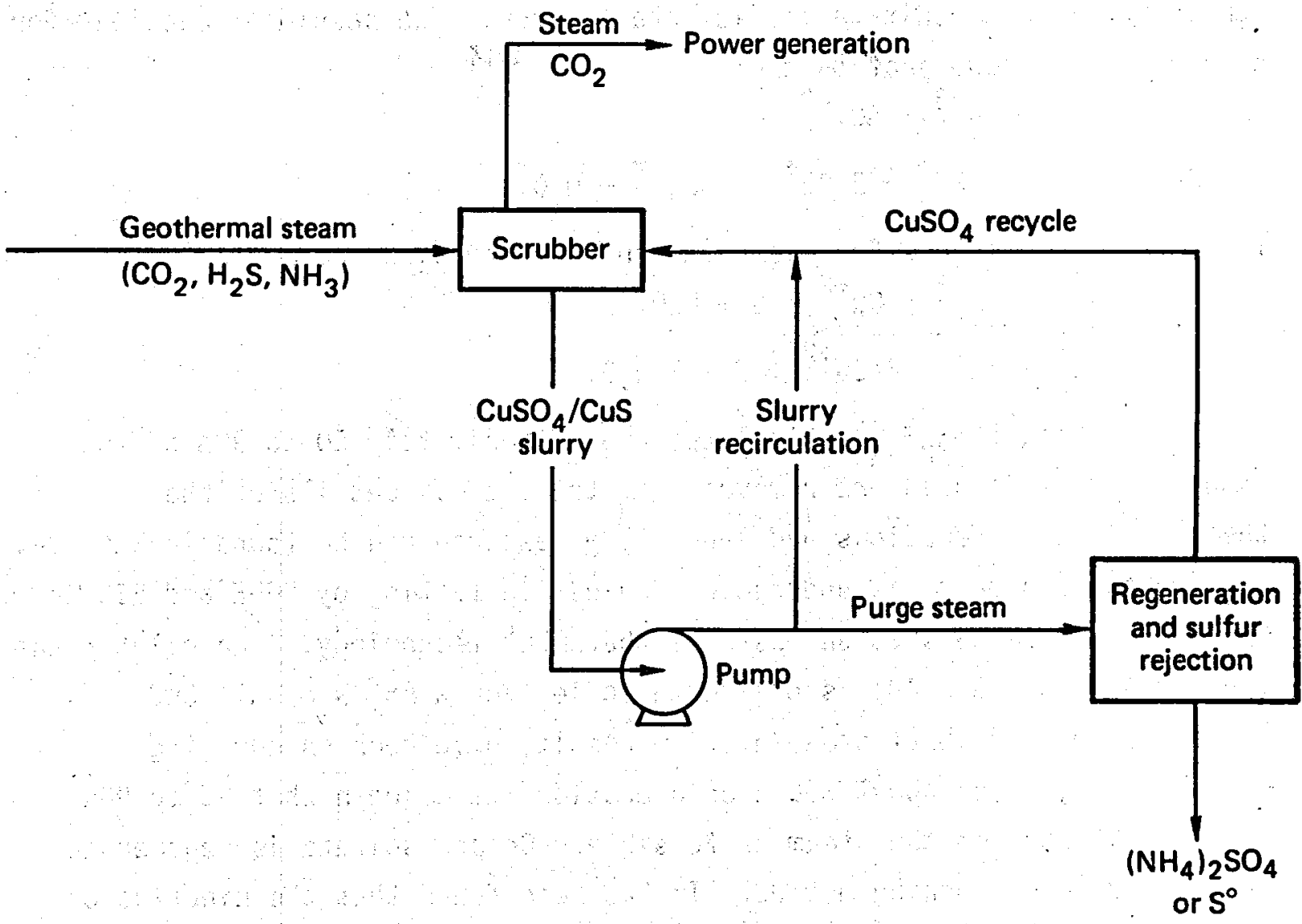

FIG. 17. Simplified flow chart of the EIC copper sulfate process.

Two methods of regenerating copper sulfate for recycling to the scrubber column can be used. Both are adaptations of methods used for production of copper metal from sulfide ores.

One is to use a "sulfating roast," which yields copper sulfate and drives off sulfur dioxide, which would have to be recovered by absorption or conversion to sulfuric acid. The reactions are as follows:

$$
\begin{aligned}
& \mathrm{CuS}+\mathrm{2O}_{2}+\mathrm{CuSO}_{4}, \\
& \mathrm{CuS}+\frac{3}{2} \mathrm{O}_{2}+\mathrm{CuO}+\mathrm{SO}_{2} .
\end{aligned}
$$


The other is acid pressure-leaching in which a slurry of copper sulfide in sulfuric acid solution is treated with air or oxygen under elevated pressure and temperature. Depending on the conditions used, the sulfide can be oxidized to sulfate or elemental sulfur. The possible reactions for copper sulfate regeneration are:

$$
\begin{aligned}
& \mathrm{CuS}+2 \mathrm{O}_{2}+\mathrm{Cu}^{+2}+\mathrm{SO}_{4}^{-2} \\
& \mathrm{Cu}_{2} \mathrm{~S}+\frac{5}{2} \mathrm{O}_{2}+2 \mathrm{H}^{+}+2 \mathrm{Cu}^{+2}+\mathrm{SO}_{4}^{-2}+\mathrm{H}_{2} \mathrm{O}
\end{aligned}
$$

The possible reactions for elemental sulfur formation are:

$$
\begin{aligned}
& \mathrm{CuS}+\frac{1}{2} \mathrm{O}_{2}+2 \mathrm{H}^{+} \rightarrow \mathrm{Cu}^{+2}+\mathrm{S}+\mathrm{H}_{2} \mathrm{O} \\
& \mathrm{Cu}_{2} \mathrm{~S}+\mathrm{O}_{2}+4 \mathrm{H}^{+}+2 \mathrm{Cu}^{+2}+\mathrm{S}+2 \mathrm{H}_{2} \mathrm{O} .
\end{aligned}
$$

In addition to $\mathrm{H}_{2} \mathrm{~S}$, particulates and approximately 80 to $90 \%$ of the ammonia and boric acid are removed from the steam. Details of the theoretical considerations and laboratory research can be found in Ref. 34 .

The above process is undergoing exhaustive testing by PG\&E and EIC on Unit 7 at the Geysers as an upstream abatement technology. The pilot plant (shown in Figs. 18 \& 19) is one-tenth scale (for a $55 \mathrm{MW} \mathrm{plant)} \mathrm{and}$ processes $100,000 \mathrm{lb}$ of steam/h. The results have been encouraging. Recent tests, after about $350 \mathrm{~h}$ of operation, have shown that 95 to $98 \%$ removal of $\mathrm{H}_{2} \mathrm{~S}$ from the steam is feasible. Copper sulfate is regenerated by the pressure-leaching method. It has been found that the kinetics of the regeneration process is better than that anticipated from laboratory experiments. If these promising results continue with additional testing, plans for a full-scale plant may be pursued.

One of the concerns of the EIC copper sulfate process has been the possible effects of entrained copper-sulfate and elemental sulfur in the scrubbed steam. Analysis of the steam downstream of the pilot plant shows less than $1 \mathrm{ppm}$ copper. It has been feared that even this small amount will eventually cause significant plating of copper on the turbine blades and other parts of the power conversion equipment, leading to corrosion by - bimetallic coupling. Because of this, PG\&E has not been returning the scrubbed steam to the turbine steam supply line. It is now thought, however, that copper entrained in the scrubed steam will react with the residual $\mathrm{H}_{2} \mathrm{~S}$ in the steam to form copper sulfide particles and thus 


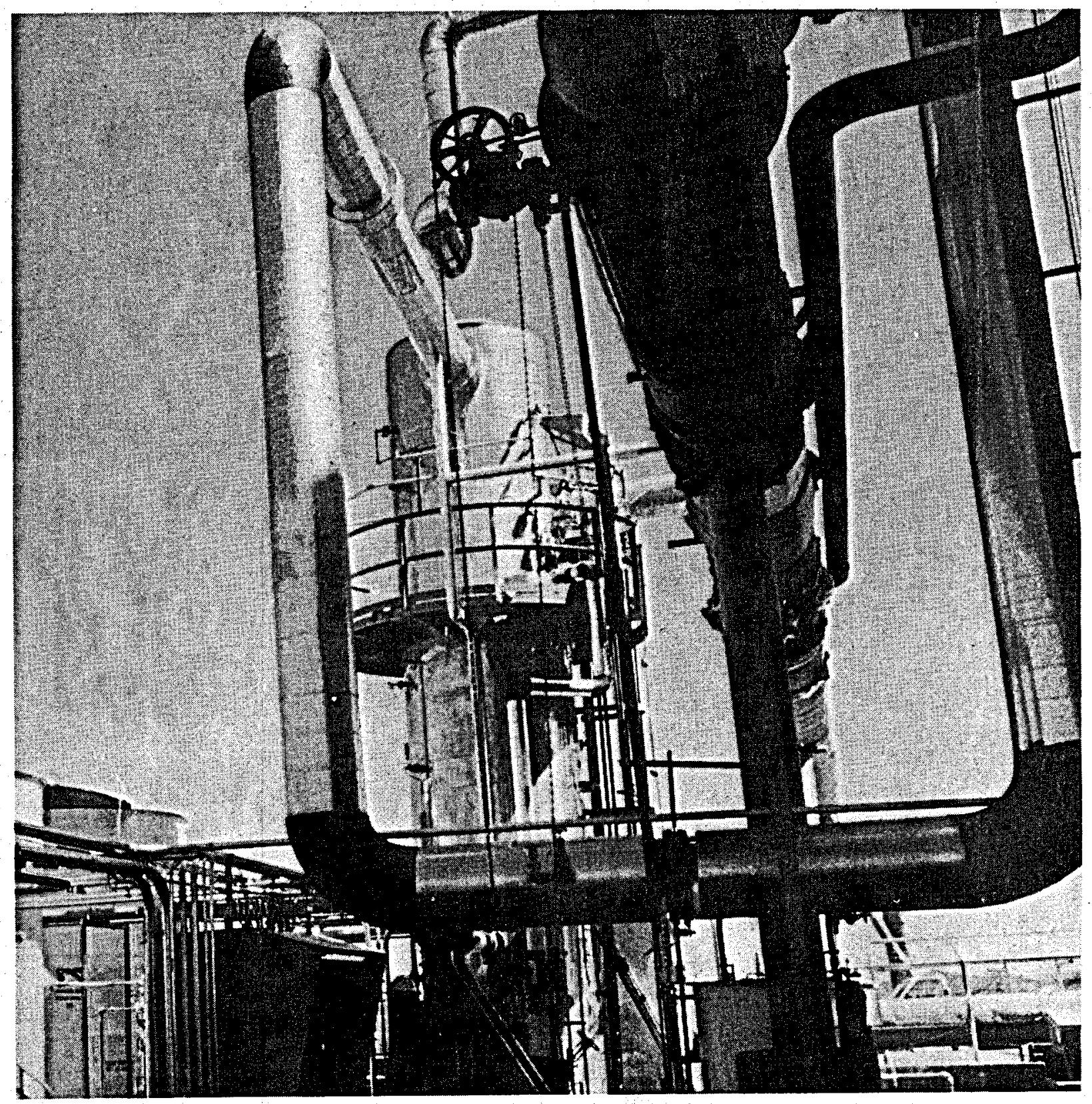

FIG. 18. Photo of the EIC process pilot plant scrubbing tower on PG\&E's Unit 7, The Geysers. 


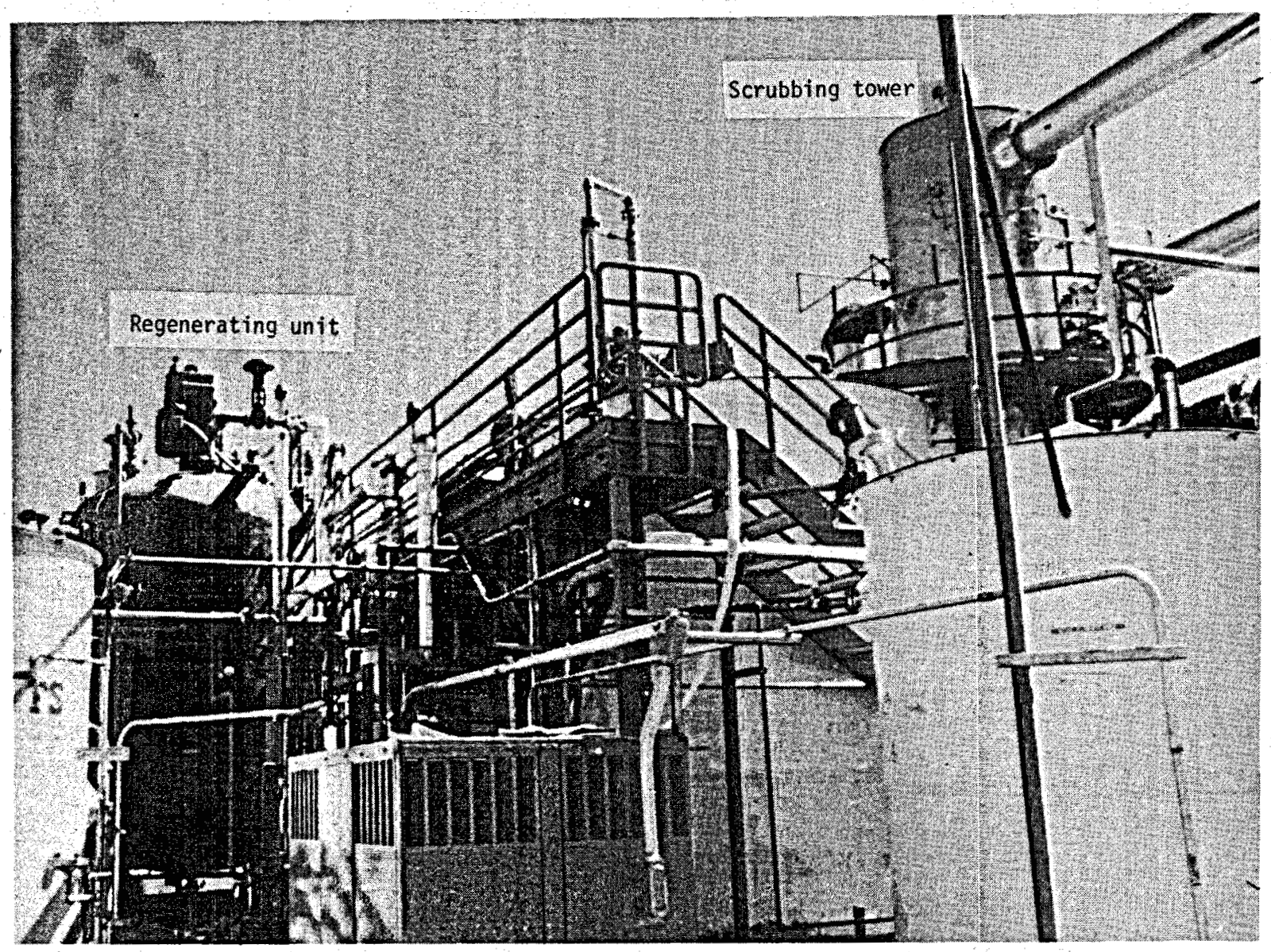

FIG. 19. Photo of the EIC pilot plant $\mathrm{CuSO}_{4}$ regeneration unit. 
eliminate the plating and bimetallic corrosion problems. On considering this hypothesis, PG\&E will soon begin returning the scrubed steam to the turbine supply line. The affect of elemental sulfur in the scrubbed steam on the turbine has not yet been determined.

\section{Solid Sorbents}

Battelle Pacific Northwest Laboratories of Hanford, Washington, has investigated several solid sorbents for the removal of $\mathrm{H}_{2} \mathrm{~S}$ from geothermal steam. 35 Two processes have been extensively studied: sorption (both physical and chemical) by solid sorbents, and catalytic oxidation in the presence of oxygen.

The solid sorbents studied were zinc oxide and a carbonaceous polymeric sorbent. Experiments showed that the materials were promising for their ability to remove $\mathrm{H}_{2} \mathrm{~S}$ from steam, but regeneration of the materials was difficult if not impossible. Regeneration of the spent carbonaceous polymeric sorbent required superheated steam in an amount equal to or more than the amount of steam treated. When zinc oxide was regenerated at $700^{\circ} \mathrm{C}$, the sorption characteristics decreased markedly. It is believed that this decrease is due to the reduced surface area of the regenerated zinc oxide, which was $5 \%$ of the original surface area. The investigators concluded that regenerating the solid sorbents tested is either technically too difficult or too expensive for practical application.

\section{Deuterium Process}

The Deuterium Corporation of White Plains, New York, has installed and tested a device to remove $\mathrm{H}_{2} \mathrm{~S} /$ from the geothermal fluid before it reaches the plant. A pilot test unit having an estimated capacity of $1,000 \mathrm{lb} / \mathrm{hr}$ (steam) was tested at the Geysers Unit 7. Early test results indicate a removal efficiency of at least $90 \%{ }^{8}$

The Deuterium process is believed to use a liquid absorption scrubber, but process details and the chemical reaction used are considered proprietary. Another process, the "GS Process" for heavy water, uses 
$\mathrm{H}_{2} \mathrm{~S}$, and the scrubbing process is intended as a component of a heavy water production facility. Development and marketing of the scrubber as a $\mathrm{H}_{2} \mathrm{~S}$ control process appears doubtful.

As shown in Fig. 15, the other route to upstream $\mathrm{H}_{2} \mathrm{~S}$ abatement is to separate the noncondensable gases from the steam and then apply an appropriate environmental control technology to remove $\mathrm{H}_{2} \mathrm{~S}$ from the off-gas stream. Steam converters are used to accomplish the separation and suitable control technologies would include the EIC copper sulfate system described above or the Stretford process to be described later. It should. be pointed out here, however, that use of the Stretford process upstream instead of downstream would obviate the need for surface (tube and shell) condensers at the power conversion plant, and thus provide a substantial saving of capital costs.

\section{Steam Converters}

Although not a true $\mathrm{H}_{2} \mathrm{~S}$ abatement process, steam converters have the capability of separating $\mathrm{H}_{2} \mathrm{~S}$ and other dissolved gases from steam. Abatement controls to remove $\mathrm{H}_{2} \mathrm{~S}$ from the separated gases would be required to supplement this process.

A schematic of a typical steam converter is shown in Fig. 20. The enthalpy of the geothermal steam fraction is transferred in a heat exchanger (converter) to a secondary stream of condensate. The steam loses part of its heat, condenses, and gases are removed in a gas stripping column. The condensate is then reflashed in the secondary coils of the heat exchanger. The basic principle of the steam converter is that when steam is condensed by removing heat, the resulting condensate is relatively free of dissolved gases which remain mostly in the gas phase. ${ }^{8}$ The heat from the condensing steam is used to reboil the clean condensate producing relatively clean steam. The condensing and reboiling processes are the two sides of the heat exchanger.

The original steam converters used at Lardarel10, Italy, were used to achieve separation of boric acid from steam. As shown in Fig. 20, a small 


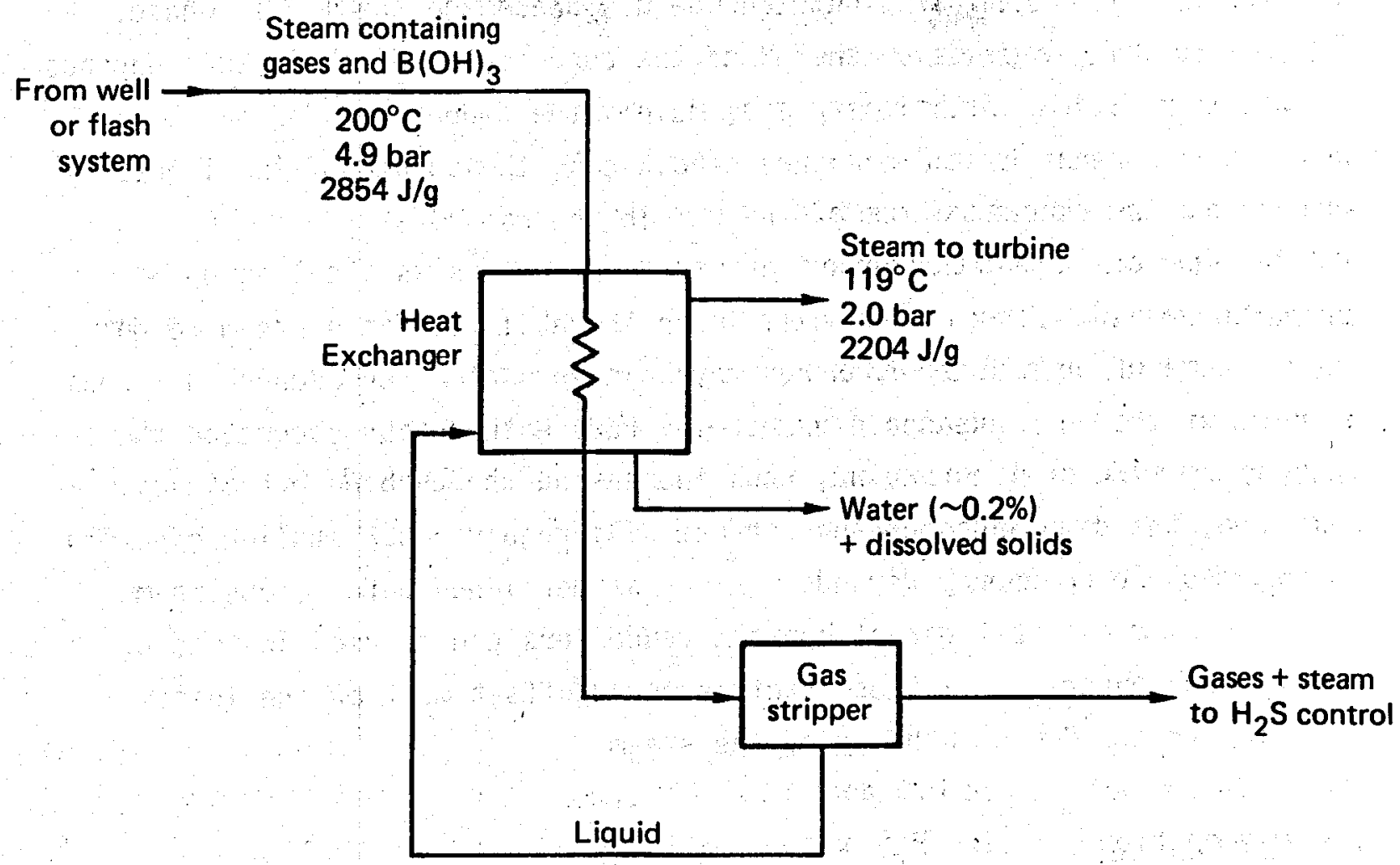

FIG. 20. Schematic of a typical steam converter unit. ${ }^{8}$.

residual condensate stream remains after evaporation, and this contains most of the boric acid. The original steam converters which date back to pre-1940 were relatively inefficient, but more recent design concepts offer the promise of relatively high efficiency.

A small steam converter, processing only several hundred pounds of steam per hour, is being tested for proof-of-concept at the Geysers by PG\&E and Coury Associates, Incorporated (Lakewood, Colorado). Prel iminary information which is sparse at this time, indicates about $90 \%$ separation of $\mathrm{H}_{2} \mathrm{~S}$ from the steam. Additional tests are underway to determine the extent of scaling, corrosion, heat loss, and other operational problems. 
The efficiency of steam converters for separating $\mathrm{H}_{2} \mathrm{~S}$ from the steam depends on its partitioning between the gas phase and the liquid phase. The partitioning depends on the $\mathrm{pH}$ of the condensate (which in turn depends on the composition of the gas phase, mainly the amounts of $\mathrm{CO}_{2}$ and $\mathrm{NH}_{3}$ ), the temperature and pressure conditions, the volume of the liquid phase, and the concentration of the $\mathrm{H}_{2} \mathrm{~S}$ in the raw steam.

Another concern with the use of steam converters is the loss of enthalphy of the steam, which will lower the ability of the steam to do work. Some of this loss of energy may be compensated for because upstream removal of the noncondensable gases will reduce the backpressure on the downstream side of the turbine, thus increasing the turbine efficiency. In addition, the diminished off-gas stream will require much smaller ejectors having much lower energy demands. Also, as mentioned before, upstream $\mathrm{H}_{2} \mathrm{~S}$ removal means that direct-contact condensers can be used instead of surface condensers. All these factors could offset most of the losses expected from reduced enthalpy of the steam.

\section{Dow Oxygenation}

The Dow oxygenation process ${ }^{36}$ is an upstream technology for liquid-dominated resources: Gaseous oxygen is used for the removal of $\mathrm{H}_{2} \mathrm{~S}$ at the wellhead. Most of the experimental work (Ref. 36) has . involved the treatment of simulated hot geothermal brine. The overall reaction which is believed to take place is as follows:

$\mathrm{H}_{2} \mathrm{~S}$ (aqueous) $+2 \mathrm{O}_{2}$ (gas) $\rightarrow \mathrm{H}_{2} \mathrm{SO}_{4}$ (aqueous).

Lesser but significant amounts of sulfide and free sulfur are also formed by other reaction paths. Approximately $90 \% \mathrm{H}_{2} \mathrm{~S}$ abatement was achieved in the laboratory at $\mathrm{pH} 7$ and $171^{\circ} \mathrm{C}$ at a 1.5 mole ratio of injected oxygen to $\mathrm{H}_{2} \mathrm{~S}$. The oxygen is injected through a flow controller into a packed column.

Corrosion is a major problem if excess oxygen is injected. This requires very close monitoring and control of the oxygen injection system. A proposed design' concept for the system is shown in Fig. 21. 


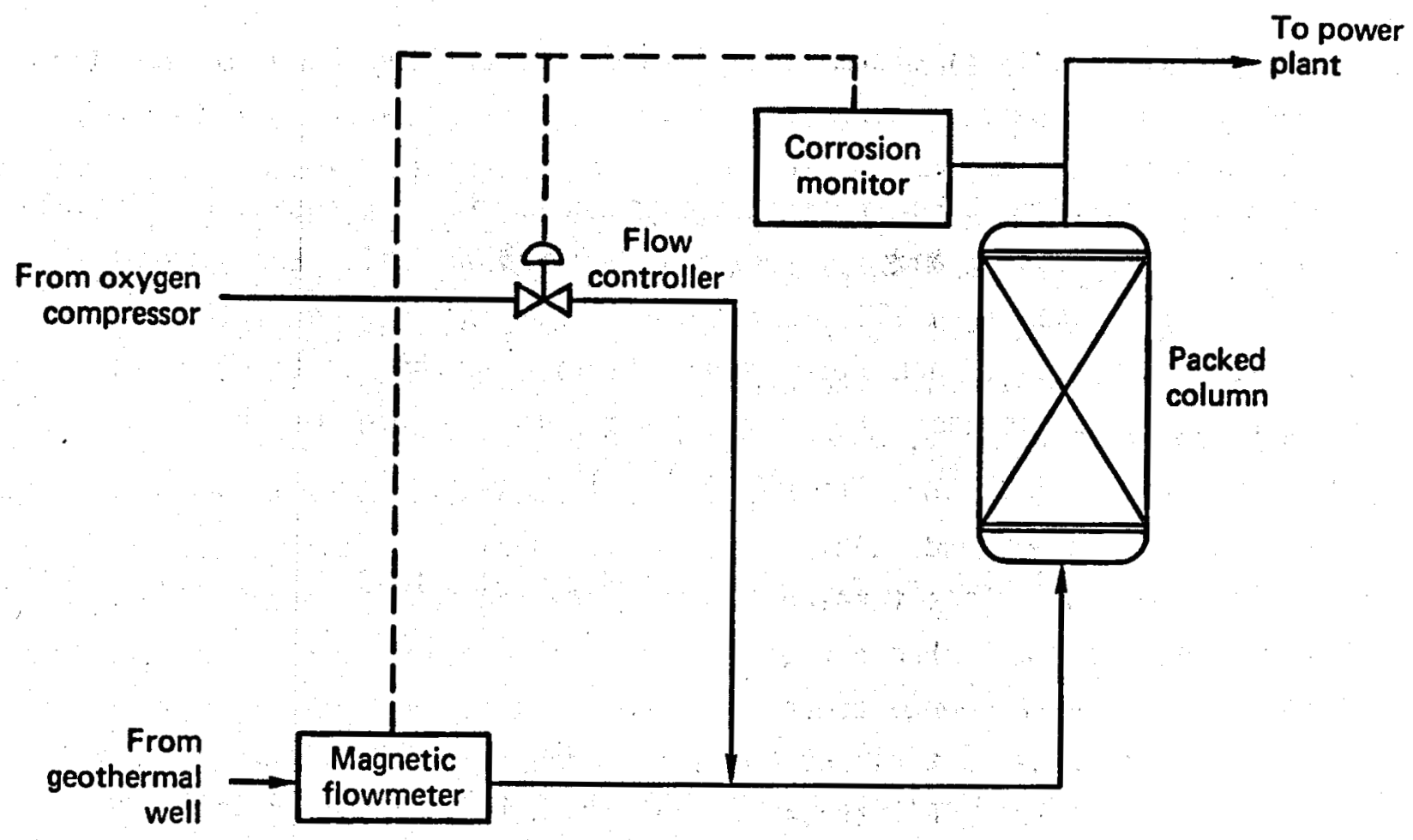

FIG. 21. Conceptual design of Dow oxygenation processing using a packed column (design case II)..$^{36}$

Reaction times with all-liquid resource fluid is about 1 min. However, the reaction with vapor is too slow to be feasible for steam or two-phase fluids. Two phases can be expected with high temperature liquid-dominated resources unless down-hole pumps are used to keep the fluid in an all-liquid state. The long term reliability of down-hole pumps has yet to be established. Because of these problems, work on this process has been discontinued.

\section{SRI Electrolytic Oxidation Process}

SRI International, under Environmental Protection Agency (EPA) funding is studying a direct electrolytic oxidation procedure for the removal of $\mathrm{H}_{2} \mathrm{~S}$ from saline solutions. The present laboratory-scale experiments are being performed in a single stage process using solutions that contain from 1 to $30 \mathrm{ppmw} \mathrm{H}_{2} \mathrm{~S}$ with salinities of $16 \mathrm{~g} \mathrm{NaCl}$ and $200 \mathrm{~g} \mathrm{NaCl} / 1$. 
The oxidation reaction

$$
\mathrm{HS}^{-}+\mathrm{S}+\mathrm{H}^{+}+2 \mathrm{e}
$$

takes place at a flow-thru vitreous carbon anode with a porosity of $95 \%$; at a temperature of $200^{\circ} \mathrm{C}$; and a pressure of 900 to 1000 psi. Early results indicate that better than $95 \%$ removal of $\mathrm{H}_{2} \mathrm{~S}$ can be achieved by the process. The system is precisely controllable, and the electrochemical aspects should be easy to scale-up. However, difficulties may be encountered with mechanical and physical scale-up.

\section{DOWNSTREAM ABATEMENT TECHNOLOGY FOR POWER PLANT EMISSIONS}

\section{Condensers and Partitioning}

When downstream technologies are used for the abatement of $\mathrm{H}_{2} \mathrm{~S}$, the major concern is the partitioning of the $\mathrm{H}_{2} \mathrm{~S}$ between the gas phase and the aqueous phase in the turbine condenser. In addition to temperature, the $\mathrm{pH}$ of the condensate is a significant factor in the distribution of the $\mathrm{H}_{2} \mathrm{~S}$. This is shown in Table 11: the lower the $\mathrm{pH}$, the more the $\mathrm{H}_{2} \mathrm{~S}$ partitions into the gas phase. The $\mathrm{pH}$ of the aqueous phase depends on the quantities of $\mathrm{H}_{2} \mathrm{~S}, \mathrm{CO}_{2}, \mathrm{NH}_{3}$, and boric acid in the steam. A discussion of condensate chemistry in contact condensers and surface condensers has been detailed by Weres et al. (Ref. 8, Sections S11.6 and S11.7).

It can also be seen that the type of condenser is important, since more $\mathrm{H}_{2} \mathrm{~S}$ is in the gas phase (at the same $\mathrm{pH}$ ) when surface condensers are used. In a surface condenser, the steam is condensed on tubes and is in contact with only the relatively small amount of its own condensate. In a direct-contact condenser, the steam is condensed by contacting a spray of cooling tower water whose volume is about twenty times greater than that of the condensate. This large volume of water, and the more intimate contact provided by the spray, increases the amount of noncondensable gases that dissolve in the aqueous phase, and decreases the amount in the gas phase. 
As previously shown in Fig. 15, the abatement technology employed to eliminate $\mathrm{H}_{2} \mathrm{~S}$ depends on the type of condenser used in the power conversion process. When a surface condenser is used, the abatement of $\mathrm{H}_{2} \mathrm{~S}$ is performed on the noncondensable off-gas stream. Units 13, 14, and 15 at the Geysers are designed with surface condensers, and the Stretford process is the abatement technology.

TABLE 11. Dependence of $\mathrm{H}_{2} \mathrm{~S}$ partitioning on $\mathrm{pH}$ and condenser $\mathrm{a}$.

$$
\% \mathrm{H}_{2} \mathrm{~S} \text { in gas phase } \% \mathrm{H}_{2} \mathrm{~S} \text { in aqueous phase }
$$

\begin{tabular}{lcc|c|ccc}
\hline (pH, aqueous phase) & $(6.5)$ & $(7.0)$ & $(7.5)$ & $(6.5)$ & $(7.0)$ & $(7.5)$ \\
Surface condenser & 93 & 89 & 79 & 7 & 11 & 21 \\
Contact condenser & 40 & 30 & 16 & 60 & 70 & 84 \\
\hline
\end{tabular}

assuming 4000 ppmw noncondensable gases in steam $(0.4 \%)$, the cubic feet of gas per pound of steam $=0.4 / 8=0.05$. The values in the table were est imated from the curves in Fig. A-2 (Appendix A).

Direct-contact condensers are used in all the other operating units at The Geysers (Units 1-12). On these units, abatement technologies that eliminate $\mathrm{H}_{2} \mathrm{~S}$ in the aqueous phase are applicalbe. The iron catalyst system is used extensively for this purpose.

Figures 22 and 23 lllustrate conversion systems employing surface condensers with gas phase abatement (Stretford process), and systems using direct-contact condensers with aqueous phase abatement (iron catalyst. process).

\section{UOP Catalytic Oxidation}

UOP catalytic oxidation (Sulfox ${ }^{*}$ process) utilizes a metal phthalocyanine compound supported by an activated carbon base to catalytically oxidize $\mathrm{H}_{2} \mathrm{~S}$ to sulfur, utilizing air as the oxidant.

* Registered trademark of UOP Incorporated. 


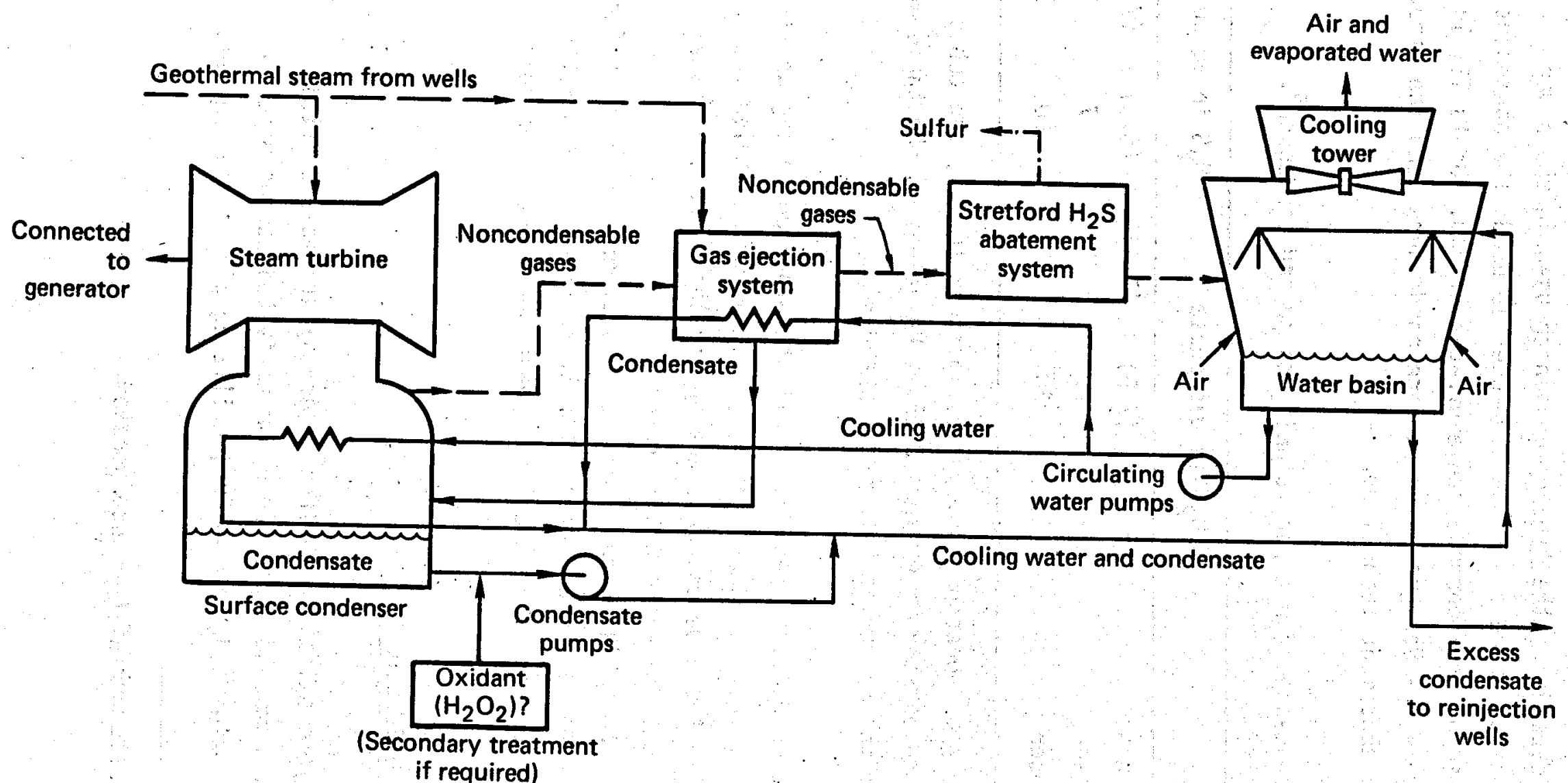

FIG. 22. Schematic of geothermal steam power plant using surface condensers with Stretford $\mathrm{H}_{2} \mathrm{~S}$ abatement unit. 


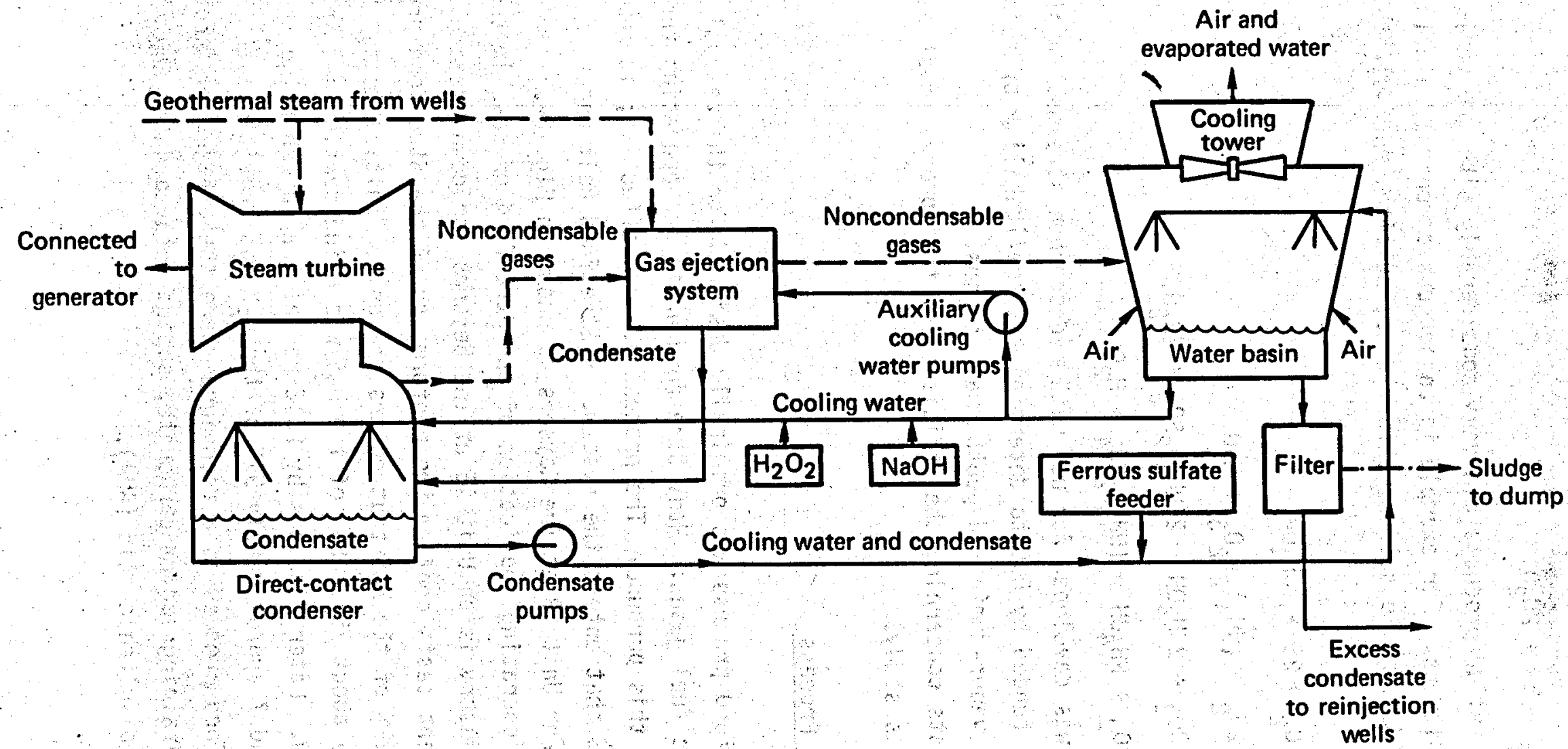

FIG. 23. Schematic of a geothermal steam power plant using direct-contact condensers with the $\mathrm{H}_{2} \mathrm{O}_{2}$-supplemented iron catalyst $\mathrm{H}_{2} \mathrm{~S}$ control system. 
The basic reaction may be uritten:

$$
2 \mathrm{H}_{2} \mathrm{~S}+\mathrm{O}_{2}+2 \mathrm{~S}+2 \mathrm{H}_{2} \mathrm{O} \text {. }
$$

The oxidized sulfur products can vary considerably with the variations of reaction conditions. For example in an aqueous ammonical solution, the following oxidations to sulfur, thiosulfate, sulfite, and sulfate can occur:

$$
\begin{aligned}
& 2 \mathrm{NH}_{4} \mathrm{SH}+\mathrm{O}_{2}+2 \mathrm{~S}+2 \mathrm{NH}_{4} \mathrm{OH}, \\
& 2 \mathrm{NH}_{4} \mathrm{SH}+2 \mathrm{O}_{2}+\left(\mathrm{NH}_{4}\right)_{2} \mathrm{~S}_{2} \mathrm{O}_{3}+\mathrm{H}_{2} \mathrm{O} \\
& 2 \mathrm{NH}_{4} \mathrm{SH}+3 \mathrm{O}_{2}+2 \mathrm{NH}_{4} \mathrm{OH}-2\left(\mathrm{NH}_{4}\right)_{2} \mathrm{SO}_{3}+2 \mathrm{H}_{2} \mathrm{O} \\
& \mathrm{NH}_{4} \mathrm{SH}+2 \mathrm{O}_{2}+\mathrm{NH}_{4} \mathrm{OH} \rightarrow\left(\mathrm{NH}_{4}\right)_{2} \mathrm{SO}_{4}+\mathrm{H}_{2} \mathrm{O}
\end{aligned}
$$

This process was developed for use with hydrocarbon streams. A study has been recently funded by DOE to determine the applicability of this method to liquid- or vapor-dominated geothermal streams.

Any comments concerning the efficiency of this process must await the results of this study.

\section{The Stretford Process}

The Stretford process was originally designed for the removal of $\mathrm{H}_{2} \mathrm{~S}$ from synthetic fuel gases. Many Stretford units are operating throughout the world for this purpose. The process is very effective; it removes over 99\% of the $\mathrm{H}_{2} \mathrm{~S}$ that enters the system. A Stretford unit under construction for Unit 13 at The Geysers is shown in Fig. 24.

The first operating application of the Stretford process in the geothermal industry is on Unit 15 at The Geysers for downstream $\mathrm{H}_{2} \mathrm{~S}$ removal. Recent tests confirm the performance of the Stretford process by abating over $99 \%$ of the $\mathrm{H}_{2} \mathrm{~S}$ that enters the unit. Initial tests indicated only about 75 to $80 \%$ of the $\mathrm{H}_{2} \mathrm{~S}$ was being partitioned into the off-gas stream. Later findings by PG\&E reveal that by shifting the $\mathrm{PH}$ to between 6.5 and 7 approximately $91 \%$ of the $\mathrm{H}_{2} \mathrm{~S}$ was partitioned.'

The Stretford process is a technique where the off-gas is scrubbed with a solution containing sodium carbonate, sodium metavanadate, and anthraquinone disulfonic acid (ADA). 


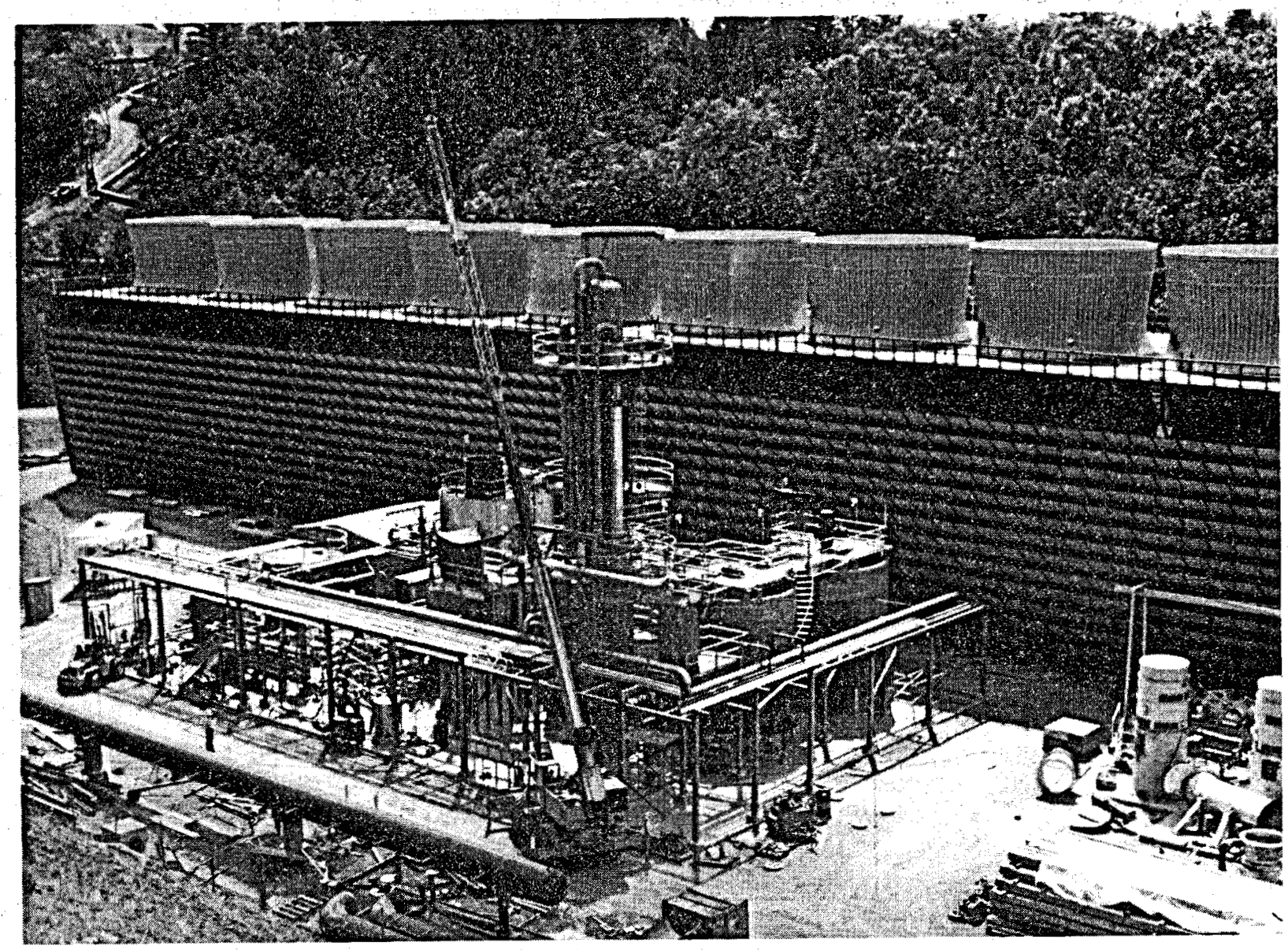

FIG. 24. Photo of a Stretford plant under construction at PG\&E's Unit 13, The Geysers.

A flow diagram of the Stretford process is shown in Fig. 25. The gas stream is scrubbed in a countercurrent flow. The $\mathrm{H}_{2} \mathrm{~S}$ is dissolved, forming bisulfide ion:

$$
\mathrm{H}_{2} \mathrm{~S}+\mathrm{CO}_{3}^{-2}+\mathrm{HS}^{-}+\mathrm{HCO}_{3}^{-} \text {. }
$$

The bisulfide ion reacts with quinquivalent vanadium to form sulfur and quadravalent vanadium:

$$
\mathrm{HS}^{-}+\mathrm{V}^{+5} \rightarrow \mathrm{S}+\mathrm{V}^{+4}
$$




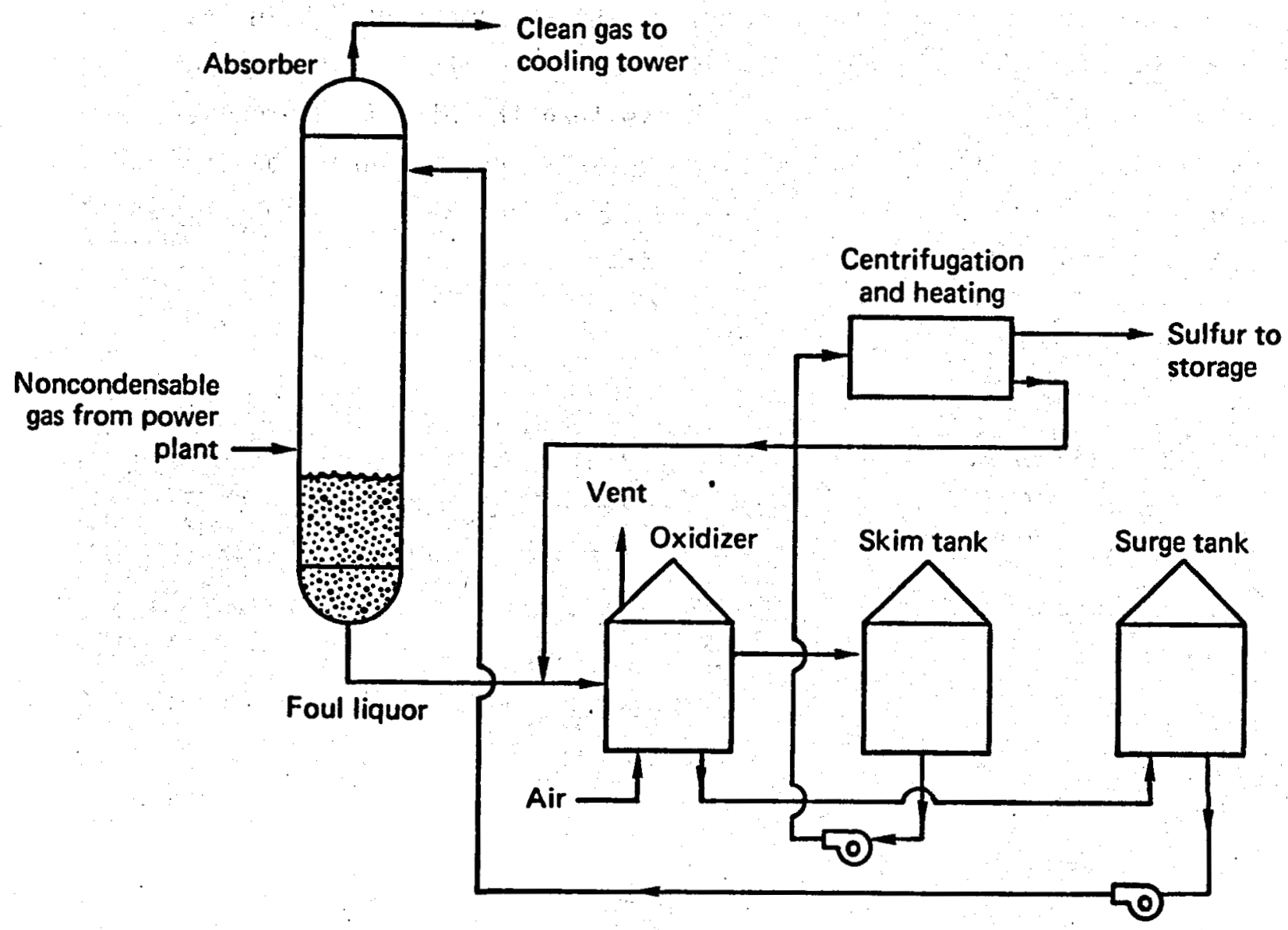

FIG. 25. Flow diagram of the Stretford process. ${ }^{37}$

The reduced vanadium is regenerated to the +5 valent state through a mechan ism involving oxygen transfer by the ADA:

$$
\begin{aligned}
& v^{+4}+A D A+v^{+5}+\text { reduced } A D A \\
& \text { reduced } A D A+\mathrm{O}_{2} \rightarrow A D A+\mathrm{H}_{2} \mathrm{O} .
\end{aligned}
$$

Air passed through the solution in the oxidizer tank not only oxidizes the ADA, but also brings the elemental sulfur to the surface as a froth. The sulfur froth is removed to a skim tank; separated; washed; and melted to produce high quality sulfur. 
Other processes have been considered for the abatement of $\mathrm{H}_{2} \mathrm{~S}$ in the off-gas stream of facilities that use either direct-contact condensers or . surface condensers. They are less attractive than the Stretford process because of high costs, low performance characteristics, or unreliability and maintenance problems. Although not considered likely candidates at the present time, they are briefly described below.

\section{Jefferson Lake Process}

The Jefferson Lake process involves a variation of the Claus process commonly used in the petroleum industry. Gases containing $\mathrm{H}_{2} \mathrm{~S}$ are reacted with $\mathrm{SO}_{2}$ in a catalytic reactor to form sulfur and water. Part of the sulfur is oxidized to form $\mathrm{SO}_{2}$, which is then recycled back to the reactor inlet.

This process is currently under investigation for use on a geothermal power plant at Cerro Prieto. Economics of the process are believed to be highly dependent on the recovery of by-product sulfur.

\section{Burner-Scrubber Process}

Noncondensable gases from geothermal fluids can be incinerated, but may require the addition of auxiliary fuel to support combustion. In the burner-scrubber process, the vent gases are incinerated, and the combustion products are scrubbed with water. Sulfur dioxide dissolved in the scrubbing liquid is returned to the condensate stream, lowering the $\mathrm{pH}$ in the condenser hotwe 11, thus causing more $\mathrm{H}_{2} \mathrm{~S}_{\text {to }}$ be removed with the vent gases.

A full-scale prototype of the burner-scrubber concept was tested on the Geysers Unit 4.38 The marginal flamability and pulsating nature of the gases from the ejectors posed some challenging engineering problems; however, these problems were overcome and the system became operational. The scrubbed $\mathrm{SO}_{2}$ proved to have relatively little effect on the condensate $\mathrm{pH}$ because of the relatively large volume of cooling water required with the direct-contact condenser design--about 20 times the 
volume of condensate. Therefore, much of, the $\mathrm{H}_{2} \mathrm{~S}$ (40 to $60 \%$ ) remained in the condensate, rather than being removed with the vent gases to the burner system. A maximum efficiency of only about $50 \%$ was achieved, based on the inlet concentration of $\mathrm{H}_{2} \mathrm{~S}^{38}$ For this reason, as well as unreliable operation and numerous equipment maintenance problems, work on this system has been discontinued by PG\&E.

\section{Catalyst-Scrubber Process}

A variation of the burner-scrubber process is the catalyst-scrubber process developed by Union 0 il Company. This process uses a catalyst to selectively oxidize $\mathrm{H}_{2} \mathrm{~S}$ to $\mathrm{SO}_{2}$. Since oxidation takes place without combustion, the system is potentially less complex and safer than the burner-scrubber process. ${ }^{37}$ However, the efficiency of this process is not expected to be much greater than about $50 \%$.

\section{Ferrox Process}

In the Ferrox process, the vent gas is compressed, cooled, then contacted with an aqueous alkaline solution of $3 \%$ sodium carbonate with 0.5\% iron oxide suspended in the solution. The iron sulfide formed is air oxidized in the regeneration step to form a slurry of sulfur, sulfides, and insoluble oxides. The slurry is filtered to remove solids and then recirculated to the system. The sulfur-containing sludge is disposed of by landfill or other means.

The Ferrox process was, at one time, widely used in plants designed to sweeten gases containing moderate amounts of $\mathrm{H}_{2} \mathrm{~S}$, but most such units have been long since converted to the Stretford process or shut down. Also, none of these units processed gases containing as much $\mathrm{H}_{2} \mathrm{~S}$ as is contained in geothermal effluents. Although it is probable that acceptable performance could be achieved by a multistage ferrox unit, some development may be required. There are also some serious chemical hazards involved in the handling of the feed and waste products of a Ferrox unit. ${ }^{39}$ 
The caustic soda process may be used to remove both $\mathrm{H}_{2} \mathrm{~S}$ and $\mathrm{CO}_{2}$ from the vent gas stream. The gas is contacted with a solution containing caustic soda $(\mathrm{NaOH})$ in a countercurrent packed tower. The spent caustic is then disposed of.

Caustic scrubbing does not appear to be an attractive process for use on most geothermal effluents since it consumes $\mathrm{NaOH}$ on a once-through basis in removing both $\mathrm{CO}_{2}$ and $\mathrm{H}_{2} \mathrm{~S}$. Thus, chemical and waste disposal costs are expected to be extremely high. Dow Chemical Company has developed a caustic scrubbing process for removing $\mathrm{H}_{2} \mathrm{~S}$ selectively from streams containing $\mathrm{CO}_{2}$, but additional development work would be required to verify the applicability of this technique to the vent gases from any given geothermal facility. 39

\section{Sodium Hypochlorite Process}

In the sodium hypochlorite process, the gas is contacted with a 1 to $2 \%$ solution of sodium hypochlorite ( $\mathrm{NaOCl}$ ) in a Venturi scrubber to yield solid sulfur, sulfites, and chlorides. Fresh $\mathrm{NaOCl}$ is continuously added to the solution, which is then recirculated back to the scrubber. There is no attempt to regenerate the solution. The $\mathrm{pH}$ is maintained at about 10.5 by the added $\mathrm{NaOCl}$ and addition of caustic solution. When the solids content reaches about 15\%, the slurry is pumped to disposal, while a fresh NaOCl makeup solution is pumped into the top of the scrubber.

The literature contains very little information regarding the use of $\mathrm{NaOCl}$ to remove large quantities of $\mathrm{H}_{2} \mathrm{~S}$ from a gas stream. Also, the manufacturers of $\mathrm{NaOCl}$ do not have sufficient data to design such a process to treat the type of gas at the Geysers with reasonable confidence of its success. Therefore, before a unit based on this process is built, some development and pilot work would be required. 39 
This process involves contacting the vent gas in a packed countercurrent tower with a 1 to $2 \%$ aqueous solution of potassium permanganate $\left(\mathrm{KMnO}_{4}\right)$. The $\mathrm{H}_{2} \mathrm{~S}$ is oxidized to sulfite ion with the formation of insoluble manganese dioxide $\left(\mathrm{MnO}_{2}\right)$. A blowdown stream is continuously withdrawn from the bottom of the packed tower and fresh $\mathrm{KMnO}_{4}$ solution is added at the top.

Potassium permanganate has been successfully used to remove $\mathrm{H}_{2} \mathrm{~S}$, mercaptans, unsaturated organic acids, and other sulfur compounds, in low concentrations from various gases. Although it has not been used to treat gases with $\mathrm{H}_{2} \mathrm{~S}$ concentrations as high as that expected for geothermal applications, it is believed that this process would be technically feasible. However, some development and pilot work would be required. There are also some serious chemical hazards associated with handling and use of $\mathrm{KMnO}_{4}$. Waste materials would require an appropriate disposal site. No cost information is currently available for this process.

\section{Iron Catalyst Process}

The iron catalyst system was developed by PG\&E for removal of $\mathrm{H}_{2} \mathrm{~S}$ from the cooling-water/condensate stream. Units 1-12 at The Geysers are equipped with direct-contact condensers where the steam is condensed by sprays of very large volumes of circulating cooling-tower water. About two-thirds of the incoming $\mathrm{H}_{2} \mathrm{~S}$ dissolves in the water and returns to the cooling tower. About one-third is removed with the noncondensable gas stream, which is also injected into the cooling tower.

To abate $\mathrm{H}_{2} \mathrm{~S}$ emissions, ferrous sulphate is added to the circulating water upstream of the cooling tower. A ferric compound was formerly used, but the ferrous salt was found to be easier to dissolve and less corrosive to the metering system. ${ }^{11}$ When the circulating water enters the cooling tower, the ferrous ion is oxidized by oxygen in the air to form ferric ion:

$$
2 \mathrm{Fe}^{+2}+\frac{1}{2} \mathrm{O}_{2}+2 \mathrm{H}^{+}+2 \mathrm{Fe}^{+3}+\mathrm{H}_{2} \mathrm{O} \text {. }
$$


The ferric ion reacts with $\mathrm{H}_{2} \mathrm{~S}$ in the aqueous phase to form elemental sulfur:

$$
\begin{aligned}
& \mathrm{H}_{2} \mathrm{~S} \text { (aqueous) } \rightarrow 2 \mathrm{H}^{+}+\mathrm{S}^{-2} \\
& 2 \mathrm{Fe}^{+3}+\mathrm{S}^{-2} \rightarrow 2 \mathrm{Fe}^{+2}+\mathrm{S}
\end{aligned}
$$

The net reaction is:

$$
\mathrm{H}_{2} \mathrm{~S}+\frac{\mathrm{T}}{2} \mathrm{O}_{2}+\mathrm{H}_{2} \mathrm{O}+\mathrm{S} \text {. }
$$

Excess ferrous ion can react to form insoluble ferrous sulfide as follows:

$$
\mathrm{Fe}^{+2}+\mathrm{S}^{-2}+\mathrm{FeS} \text {. }
$$

The solid ferrous sulfide adds to the sludge loading, which tends to block pipes and passageways in the cooling tower. Therefore, ferrous sulfate must be carefully metered into the cooling water.

To assure more complete oxidation of ferrous ion to ferric ion and maximize $\mathrm{H}_{2} \mathrm{~S}$ removal, the process has been modified to include the addition of $\mathrm{H}_{2} \mathrm{O}_{2}$ to the circulating water just before it enters the condenser. Sodium hydroxide is also added to maintain the optimum pH range (7.4 to 7.8$) .11$ This hydrogen peroxide-supplemented iron catalyst system is now being used on Units $3 \& 4$ with abatement efficiency improved to about $90 \%$.

Corrosion is still a major problem with the iron catalyst system; as a result, mild steel fittings are being changed to stainless steel fittings. Also, carryover in the cooling-tower drift is indicated by a rust-colored coating on everything in the immediate vicinity of the plants.

The sulfur formed by the chemical reactions forms a sludge on the bottom of the cooling towers which is pumped off, filtered, and transported to a disposal site.

A schematic diagram of the $\mathrm{H}_{2} \mathrm{O}_{2}$-supplemented iron catalyst $\mathrm{H}_{2} \mathrm{~S}$ removal system has been shown in Fig. 23. 


\section{Hydrogen Peroxide Process}

The FMC Corporation has recently conducted laboratory experiments on - oxidation of $\mathrm{H}_{2} \mathrm{~S}$ in samples of cooling-water/condensate streams taken from the Geysers power plant. The experiments were conducted with variations in the following parameters: $\mathrm{H}_{2} \mathrm{~S}$ solution concentration; $\mathrm{pH}$; temperature; $\mathrm{H}_{2} \mathrm{O}_{2}$ to $\mathrm{H}_{2} \mathrm{~S}$ weight ratio; and ferric ion catalyst concentration. 40

Hydrogen peroxide reacts with $\mathrm{H}_{2} \mathrm{~S}$ in acidic or neutral solutions to form elemental sulfur and water:

$$
\mathrm{H}_{2} \mathrm{O}_{2}+\mathrm{H}_{2} \mathrm{~S}+\mathrm{S}+\mathrm{H}_{2} \mathrm{O} \text {. }
$$

In alkaline solutions, sulfide ion reacts with $\mathrm{H}_{2} \mathrm{O}_{2}$ to form sulfate and water:

$$
\begin{aligned}
& \mathrm{H}_{2} \mathrm{~S} \text { (aqueous) }-2 \mathrm{H}^{+}+\mathrm{S}^{-2} \\
& \mathrm{~S}^{-2}+4 \mathrm{H}_{2} \mathrm{O}_{2} \rightarrow \mathrm{SO}_{4}^{-2}+4 \mathrm{H}_{2} \mathrm{O} .
\end{aligned}
$$

These reactions proceed rapidly in the presence of iron catalyst in trace amounts (about $2 \mathrm{ppm}$ ), the reaction time being about $15 \mathrm{~s}$. This is about the time normally taken for the circulating water to travel from the condenser to the cooling tower.

Results from FMC experiments indicate that the use of $\mathrm{H}_{2} \mathrm{O}_{2}$ for the oxidation of $\mathrm{H}_{2} \mathrm{~S}$ is feasible. Costs and handling problems may be significant. The oxidant is not regenerable.

\section{Ozone}

The use of ozone to oxidize $\mathrm{H}_{2} \mathrm{~S}$ in aqueous solutions has not been adequately investigated to evaluate its applicability for controlling emissions from geothermal sources. However, ozone has been used to oxidize $\mathrm{H}_{2} \mathrm{~S}$ in the gaseous phase. Elemental sulfur and sulfate are the most likely products of a $\mathrm{H}_{2} \mathrm{~S}$ ozone aqueous reaction. 37

$$
\begin{aligned}
& 3 \mathrm{H}_{2} \mathrm{~S}+\mathrm{O}_{3}+3 \mathrm{~S}+3 \mathrm{H}_{2} \mathrm{O} \\
& 3 \mathrm{H}_{2} \mathrm{~S}+4 \mathrm{OO}_{3}+3 \mathrm{H}_{2} \mathrm{SO}_{4} .
\end{aligned}
$$

The feasibility of this process will depend on which of the two reactions dominate since the second reaction requires four times as much ozone as the 
first one. Therefore the cost of producing ozone will be a major factor in developing this process.

\section{Wackenroder Reaction}

The Wackenroder reaction is the liquid phase equivalent of a Claus reaction:

$$
2 \mathrm{H}_{2} \mathrm{~S}+\mathrm{SO}_{2} \rightarrow 3 \mathrm{~S}+2 \mathrm{H}_{2} \mathrm{O} \text {. }
$$

Laboratory experiments were performed at PG\&E to determine the feasibility of $\mathrm{SO}_{2}$ injection for $\mathrm{H}_{2} \mathrm{~S}$ control in condensate/cooling water. Such experiments evidently were successful in removing part of the $\mathrm{H}_{2} \mathrm{~S}^{24}$ No published reports of this work are available.

The Wackenroder reaction was part of the basis from which the burner-scrubber concept evolved, al though measured rates of reaction between $\mathrm{SO}_{2}$ and $\mathrm{H}_{2} \mathrm{~S}$ are very slow. No attempt has been made to use catalysts to accelerate the reaction rate.

\section{Brine Scrubbing Process}

A simple and inexpensive method for removing $\mathrm{H}_{2} \mathrm{~S}$ from noncondensable gas streams was identified and initially tested by LLL. When geothermal liquids are flashed to produce steam the ir pH increases. Hydrogen sulfide is much more soluble in the cool, higher $\mathrm{pH}$ fluid than in the original hot, lower pH fluid. Therefore, the spent fluid can be used to reabsorb $\mathrm{H}_{2} \mathrm{~S}$ from the noncondensable gas stream.

The method is particularly applicable for use with Salton Sea and Brawley geothermal field brines which are known to contain heavy metal ions. The $\mathrm{H}_{2} \mathrm{~S}$ absorbed in the brine reacts to form insoluble heavy metal sulfides which precipitate out and are removed prior to reinjection. At the Salton Sea geothermal field, the brines contain on the order of $65 \mathrm{ppm}$ $\mathrm{Pb}, 280 \mathrm{ppm} \mathrm{Zn}$, and $270 \mathrm{ppm} F \mathrm{Fe}$, far in excess of the stoichiometric 
quantity necessary to react with all the $\mathrm{H}_{2} \mathrm{~S}$. The reabsorption of $\mathrm{H}_{2} \mathrm{~S}$ in the spent brine is favorable because of the new equilibrium established between the gas and liquid at lower temperature and higher $\mathrm{pH}^{41}$

The precipitation of metal sulfides is also the sulfide eliminating step in the EIC copper sulfate process. ${ }^{34}$ But unlike that process, using spent geothermal fluid eliminates chemical feed costs, regeneration steps, and problems that may be associated with slurry pumping and recirculation. 41

A brief test at the Geothermal Loop Experimental Facility (GLEF) by Magma Geothermal and SDG\&E using the reaction chamber of a $30 \mathrm{gpm}$ EIMCO clarifier as the contactor, indicated scrubbing efficiencies on the order of $97 \% .42$ This adaptation of the brine scrubbing process combines $\mathrm{H}_{2} \mathrm{~S}$ abatement with preinjection clarification. There are minimal added plant costs as well as potential beneficial effects with respect to clarifier efficiency and mineral recovery from the sludge. ${ }^{41}$

In order to achieve high overall abatement of $\mathrm{H}_{2} \mathrm{~S}$, a surface-type steam condenser will be required to minimize the volume of liquid in contact with $\mathrm{H}_{2} \mathrm{~S}$ in the gas phase, and thereby maximize the amount of gaseous $\mathrm{H}_{2} \mathrm{~S}$ to be ultimately scrubbed. ${ }^{41}$

Partitioning of the $\mathrm{H}_{2} \mathrm{~S}$ in the surface condenser will be a factor in the overall abatement efficiency. The amount of $\mathrm{H}_{2} \mathrm{~S}$ retained in the brine and subsequently desorbed in the lower flash stages and evolved with the low pressure steam, may still pose a problem.

This process may become the preferred $\mathrm{H}_{2} \mathrm{~S}$ abatement on liquid-dominated resources. It would be particularly applicable to resources such as those in the Salton Sea KGRA where heavy metal recovery may become an important by-product of power production, because $\mathrm{H}_{2} \mathrm{~S}$ is a valuable reagent for use in mineral processing.

Benfield

The Benfield (hot carbonate) process is a gas-liquid absorption process. Gas to be purified is introduced into an absorber column below a 
packed section. It flows upward through the packed bed and is contacted with fresh potassium carbonate $\left(\mathrm{K}_{2} \mathrm{CO}_{3}\right)$ solution flowing downward. Purified gas exits at the top of the absorber and spent solution is withdrawn at the base. The reaction is:

$$
\mathrm{K}_{2} \mathrm{CO}_{3}+\mathrm{H}_{2} \mathrm{~S} \rightarrow \mathrm{KHCO}_{3}+\mathrm{KHS} \text {. }
$$

The spent solution is regenerated while passing downward through a second packed column, the stripper, against a rising flow of steam. Steam is condensed and separated from the acid gas and refluxed to the stripper. The $\mathrm{H}_{2} \mathrm{~S}$ then goes to a sulfur recovery unit such as a Stretford or Claus unit.

While the Benfield process is rather widely used to provide acid-gas free process streams (over 400 units are in use) the requirement of a separate sulfur recovery system severely limits its usefulness for $\mathrm{H}_{2} \mathrm{~S}$ control for geothermal energy.

\section{ANALYSIS AND ASSESSMENT OF ABATEMENT SYSTEMS}

COSTS

Cost data for the control technologies described in the previous section are limited or in some cases not available. Recent published estimates are contained in Ref. 43. The cost estimates from Ref. 43 for four candidate technologies are presented as Appendix B. Table 12 compares those costs. 
TABLE 12. Cost of four candidate technologies ${ }^{a}$

\begin{tabular}{llc}
\hline \multicolumn{1}{c}{ Process } & $\begin{array}{c}110 \mathrm{MW} \text { plant } \\
\text { mills/kwh }\end{array}$ & $\begin{array}{c}\text { Total annual cost, } \\
\$\end{array}$ \\
\hline Stretford & $0.45^{\mathrm{b}}$ & 460,500 \\
Iron catalyst & $0.40^{\mathrm{b}}$ & $378,300^{\mathrm{f}}$ \\
EIC copper sulfate & $2.0^{\mathrm{C}}$ & $1,050,700$ \\
Dow oxygenation & $7.4^{\mathrm{d}}$ & $6,600,300$ \\
\hline
\end{tabular}

${ }^{a}$ Cost estimates from Ref. 43 (Appendix B) reflect the dollar as of the end of second quarter 1977.

b Based on 220 ppom $\mathrm{H}_{2} \mathrm{~S}$.

CBased on $830 \mathrm{ppm} \mathrm{H}_{2} \mathrm{~S}$.

$d_{\text {Based on }} 500 \mathrm{ppm} \mathrm{H}_{2} \mathrm{~S}$, packed column system.

e For a $98.2 \mathrm{MW}$ plant.

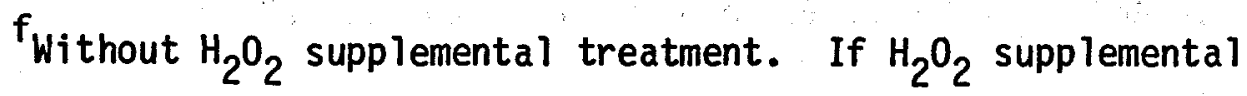
treatment is used, the additional annual cost for $\mathrm{H}_{2} \mathrm{O}_{2}$ alone would be $\$ 1,848,000$ for a total of $\$ 2,226,300$. The additional cost/kWh would be 2.4 mills for a total of $2.8 \mathrm{mills} / \mathrm{kWh}$. (Assumptions: $\$ 0.60 / 1 \mathrm{~b}$ for $\mathrm{H}_{2} \mathrm{O}_{2}, 220 \mathrm{ppm} \mathrm{H} \mathrm{H}_{2} \mathrm{~S}, 80 \%$ plant operating factor, and $1: 1$ mole ratio $\mathrm{H}_{2} \mathrm{O}_{2}: \mathrm{H}_{2} \mathrm{~S}$.)

\section{TECHNICAL EVALUATION}

A comparative analysis of six technical factors for $\mathrm{H}_{2} \mathrm{~S}$ control processes is shown as Table 13. These factors, related to the application of the processes to geothermal $\mathrm{H}_{2} \mathrm{~S}$ abatement, are discussed below.

(1) Potential for $\mathrm{H}_{2} \mathrm{~S}$ removal refers to the overall abatement efficiency that may be expected from the process. An exception is the value given for the Stretford process which is (as noted) for the unit itself; the overall efficiency will depend on partitioning efficiency.

(2) Status denotes the degree of development of the process. The code letters in the table are explained in the table footnotes. 
TABLE 13. Evaluation of $\mathrm{H}_{2} \mathrm{~S}$ control processes for geothermal application.

\begin{tabular}{|c|c|c|c|c|c|c|}
\hline Removal process & $\begin{array}{l}\text { Potential } \\
\mathrm{H}_{2} \mathrm{~S} \text { removal, } \\
\%\end{array}$ & Status $^{\mathbf{a}}$ & $\begin{array}{c}\text { Ease of } \\
\text { adaptability, } \\
(+,-)\end{array}$ & $\begin{array}{l}\text { Cross- } \\
\text { media } \\
\text { impacts }\end{array}$ & $\begin{array}{l}\text { Estimated } \\
\text { reliability }\end{array}$ & $\begin{array}{l}\text { Negative } \\
\text { factors }\end{array}$ \\
\hline $\begin{array}{l}\text { Upstream } \\
\text { Steam converters } \\
\text { EIC copper sulfate } \\
\text { Deuterium } \\
\text { Solid sorbents } \\
\text { Dow oxygenation } \\
\text { UOP catalytic oxidation } \\
\text { SRI electrolytic Oxidation }\end{array}$ & $\begin{array}{l}90+ \\
98 \text { to } 99 \\
90 \\
\text { unknown } \\
90 \text { to } 100 \\
\text { unknowm } \\
>95\end{array}$ & $\begin{array}{l}C^{b} \\
P \\
P \\
L \\
L \\
S \\
L\end{array}$ & $\begin{array}{l}+ \\
+ \\
+ \\
+ \\
+ \\
+ \\
+\end{array}$ & $\begin{array}{l}\text { none } \\
\text { s fudge } \\
\text { unknown } \\
\text { unknown } \\
\text { none } \\
\text { unknown } \\
\text { unknown }\end{array}$ & $\begin{array}{l}\text { excellent } \\
\text { excellent } \\
\text { unknown } \\
\text { poor } \\
\text { good } \\
\text { unknown } \\
\text { unknown }\end{array}$ & $\begin{array}{l}\text { heat loss } \\
\text { entrainment? } \\
\text { proprietary } \\
\text { costly } \\
\text { corrosion } \\
\text { unknown } \\
\text { unknown }\end{array}$ \\
\hline $\begin{array}{l}\text { Downstream } \\
\text { Iron catalyst } \\
\text { Hydrogen peroxide } \\
\text { Ozone } \\
\text { Wackenroder } \\
\text { EIC copper sulfate } \\
\text { Brine scrubbing }\end{array}$ & $\begin{array}{l}80 \text { to } 90 \\
80 \text { to } 90 \\
\text { unknown } \\
\text { unknown } \\
98 \text { to } 99 \\
80 \text { to } 90\end{array}$ & $\begin{array}{l}U \\
L \\
L \\
L\end{array}$ & $\begin{array}{l}+ \\
+ \\
? \\
? \\
+ \\
+\end{array}$ & $\begin{array}{l}\text { sludge } \\
\text { unknown } \\
\text { unknown } \\
\text { unknown } \\
\text { sludge } \\
\text { unknown }\end{array}$ & $\begin{array}{l}\text { good } \\
\text { unknown } \\
\text { unknown } \\
\text { unknown } \\
\text { unknown } \\
\text { unknown }\end{array}$ & $\begin{array}{l}\text { corrosion } \\
\text { costly? } \\
\text { costly } \\
\text { unknown } \\
\text { unknown } \\
\text { unknown }\end{array}$ \\
\hline $\begin{array}{l}\text { Off-gas stream } \\
\text { Stretford } \\
\text { Jefferson Lake } \\
\text { Burner-scrubber } \\
\text { Ferrox } \\
\text { Caustic soda } \\
\text { Sodium hypochiorite } \\
\text { Potassium permanganate } \\
\text { EIC copper sulfate } \\
\text { Benfield }\end{array}$ & $\begin{array}{l}99+c \\
\text { unknown } \\
50 \\
\text { unknown } \\
\text { unknown } \\
\text { unknown } \\
\text { unknown } \\
98 \text { to } 99 \\
\text { unknown }\end{array}$ & $\begin{array}{l}U \\
L \\
D \\
A \\
L \\
S \\
S \\
S \\
S\end{array}$ & $\begin{array}{l}+ \\
+ \\
? \\
+ \\
? \\
? \\
?\end{array}$ & $\begin{array}{l}\text { none } \\
\text { unknown } \\
\mathrm{SO}_{2} \\
\text { sludge } \\
\text { sludge } \\
\text { wastewater } \\
\text { sludge } \\
\text { sludge } \\
\text { unknown }\end{array}$ & $\begin{array}{l}\text { excellent } \\
\text { unknown } \\
\text { poor } \\
\text { unknown } \\
\text { unknown } \\
\text { unknown } \\
\text { unknown } \\
\text { unknown } \\
\text { unknown }\end{array}$ & $\begin{array}{l}\text { none } \\
\text { complex } \\
\text { many } \\
\text { unknown } \\
\text { hazardous } \\
\text { hazardous } \\
\text { hazardous } \\
\text { unknown } \\
\text { produces } \mathrm{H}_{2} \mathrm{~S}\end{array}$ \\
\hline
\end{tabular}

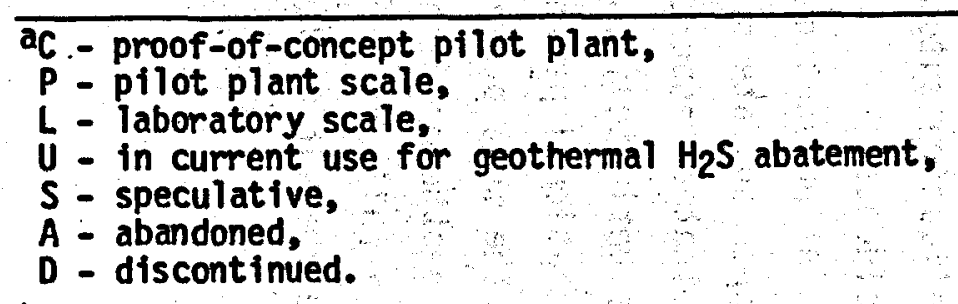

bTechnology to apply this process to a full scale unit has been demonstrated by Resources, Conservation Company (RCC). cStretford unit oniy; overall abatement efficiency depends on partitioning (see text). 
(3) Ease of adaptability indicates whether the process can be adapted to geothermal application in a practical manner, based on its present state of development. A "+" means it may be practical, a "-" signifies it is not practical at this time, and a "?" means there is not enough information available to make a determination of the practicality of the process.

(4) Cross-media impacts indicate whether the process produces other environmental problem with its use. Examples are the production of toxic. sludges or emissions.

(5) Estimated reliability refers to the "excellent", "good", or "poor" performance shown or estimated for the process, based on known actual use or pilot plant studies. As can be seen in the table, many of the processes are not advanced enough in development to make a judgment for this factor.

(6) Negative factors point out the most apparent negative factor for the process. Some are not serious concerns because the associated problems could probably be diminished by additional research or pilot plant studies. Some, denoted as hazardous, involve the handling and transportation of large quantities of hazardous chemicals, thus also qualifying as cross-media impacts.

\section{CONCLUSIONS}

The best candidate technologies for geothermal $\mathrm{H}_{2} \mathrm{~S}$ abatement are those that can be applied upstream of the conversion plant. Upstream application automatically provides $\mathrm{H}_{2} \mathrm{~S}$ abatement during steamstacking incidents.

At present one of the best candidates for upstream abatement is the EIC copper sulfate process for both vapor-dominated resources, and liquiddominated resources using flashed steam. The EIC copper sulfate process has definitely established proof-of-concept status along with successful operational performance in moderate-scale pilot plant studies. It is one of the most promising state of the art technologies for future application to geothermal abatement of $\mathrm{H}_{2} \mathrm{~S}$. Whether the process will be as effective in a full-scale upstream application remains to be determined. Indications are that it will, but scale-up problems can be significant. 
The steam converter with a Stretford unit for $\mathrm{H}_{2} \mathrm{~S}$ abatement is another very promising candidate technology for upstream abatement. This process has been well demonstrated in other applications.

For liquid-dominated resources, the binary conversion system along with total spent fluid injection offers satisfactory $\mathrm{H}_{2} \mathrm{~S}$ abatement. At this time, the Dow oxygenation process is the best candidate for upstream treatment of the fluid itself. It is the only feasible laboratory proof-of-concept treatment for geothermal liquids. Corrosion control is the major problem, but computerized feedback for precise control of oxygen injection into the fluid may be the answer.

The Deuterium process has good potential for upstream $\mathrm{H}_{2} \mathrm{~S}$ abatement, but due to its proprietary status, is not a viable imminent possibility. It should however, remain as a consideration for future application.

The proposed method of scrubbing flashed steam off-gases with spent geothermal liquid is a promising candidate for liquid-dominated resources, provided condenser partitioning is favorable.

It has been previously stated that the best candidate technologies are those processes that can be applied upstream of the conversion plant. Until comercial upstream processes are avallable, the only alternative for the Geysers is to continue to apply the existing control technologies downstream of the conversion process. These are the commercially available Stretford process and the $\mathrm{H}_{2} \mathrm{O}_{2}$ supplemented iron catalyst process. Both are currently being used at the Geysers; the Stretford process on the off-gas stream at Unit 15, and the iron catalyst process on the condensate/cooling water of most of the other generating units.

\section{RECOMMENDATIONS FOR FUTURE ENVIRONMENTAL CONTROL TECHNOLOGY}

The following are recomendations for future environmental control technology programs:

(1) High priority should be given to a study addressing $\mathrm{H}_{2} \mathrm{~S}$ emjssions associated with steam stacking and standby well bleeding. The study should include a systems level investigation to identify $\mathrm{H}_{2} \mathrm{~S}$ control technology options and assess their problems, needs, costs, and benefits. 
(2) Examine the possibility of using the Stretford process applied upstream directly on the steam for $\mathrm{H}_{2} \mathrm{~S}$ removal in much the same manner as the EIC copper sulfate process. Both are scrubbing processes. As discussed in Section VI, the Stretford process oxidizes $\mathrm{H}_{2} \mathrm{~S}$ to sulfur by means of $v^{+5}$, which reduces to $v^{+4}$. Anthraquinone disulfonic acid is used as a regenerable catalyst to reoxidize $v^{+4}$. Anthraquinone disulfonic acid is used as a regenerable catalyst to reoxidize $V^{+4}$ to : $v^{+5}$ in the presence of oxygen, so that the $v^{+5}$ can be again used to react with additional $\mathrm{H}_{2} \mathrm{~S}$ when recycled to the scrubbing tower. One foreseen problem is the loss of ADA by steam distillation as the steam passes through the tower.

Instead of reoxidizing the $\mathrm{v}^{+4}$ through the ADA mechanism, it may be possible to reoxidize the $v^{+4}$ electrolytically through the following reaction:

$$
v^{+4} \rightarrow v^{+5}+e^{-}
$$

This would obviate the necessity of using ADA as a catalytic oxygen carrier. Laboratory experiments on Stretford solution could determine the feasibility and efficiency of this reaction scheme.

(3) Steam converter technology is a valuable upstream $\mathrm{H}_{2} \mathrm{~S}$ control process when combined with an off-gas abatement technique. Further work should be done on the steam converter for geothermal applications.

(4) The Dow oxygenation process needs additional research to determine the best method of monitoring and controlling the oxygen used to eliminate $\mathrm{H}_{2} \mathrm{~S}$ in geothermal liquid resources. The application of modern computer technology should be able to provide precise and almost instantaneous process control for maximum $\mathrm{H}_{2} \mathrm{~S}$ abatement, as we 11 as minimum corrosion effects.

(5) It has been pointed out that Dow Chemical Company has developed a caustic soda $\mathrm{NaOH}$ process for selectively removing $\mathrm{H}_{2} \mathrm{~S}$ from streams containing $\mathrm{CO}_{2}$. The caustic solution must however, be disposed of, requiring transportation of large amounts of spent and fresh caustic solution. 
Experiments could be undertaken to determine the feasibility of regenerating the caustic solution by an electrolytic process. The basic reactions for removal of $\mathrm{H}_{2} \mathrm{~S}$ are as follows:

$$
\mathrm{OH}^{-}+\mathrm{H}_{2} \mathrm{~S} \rightarrow \mathrm{HS}^{-}+\mathrm{H}_{2} \mathrm{O}
$$

and

$$
\mathrm{OH}^{-}+\mathrm{HS}^{-}+\mathrm{S}^{-2}+\mathrm{H}_{2} \mathrm{O}
$$

the overall reaction being:

$$
2 \mathrm{H}^{-}+\mathrm{H}_{2} \mathrm{~S}+\mathrm{S}^{-2}+2 \mathrm{H}_{2} \mathrm{O} \text {. }
$$

An electrolytic procedure may result in the following:

$$
\mathrm{S}^{-2}+2 \mathrm{H}_{2} \mathrm{O} \rightarrow \mathrm{S}+\mathrm{H}_{2}+2 \mathrm{OH}^{-} \text {, }
$$

thus regenerating the caustic solution and greatly diminishing the caustic transportation hazard.

(6) Follow-up studies of the DOE-sponsored ASCOT program (see Section V) will be required to determine the degree of abatement actually needed in a given area. Where stringent controls are not needed, it may be possible to use more economical abatement systems and to avoid the use of systems requiring hazardous chemicals.

(7) Pilot plant studies on the EIC copper sulfate process should continue in order to aid designers of a full-scale plant. Many design parameters can be determined readily when an operating pilot plant is available to answer design questions.

(8) A study should be undertaken to develop reliable sampling and analysis methods for the quantification of $\mathrm{H}_{2} \mathrm{~S}$ in vented steam. Techniques for sampling turbulent flow in stacks, vent pipes, and other exhausts need to be examined, as well as the optimum analytical methods for $\mathrm{H}_{2} \mathrm{~S}$.

(9) Since there are no existing viable processes for $\mathrm{H}_{2} \mathrm{~S}$ removal from liquid geothermal resources, promising techniques such as the SRI electrolytic oxidation experiments should continue to be investigated. 
The authors wish to acknowledge the valuable help provided by reviewers of the report. These include D. Boehme (DOE), T. Molloy (PG\&E), and R. Reynolds (Lake County APCD). In addition, input was provided by others with expertise in the goethermal industry; G. Allen (PG\&E), M. McKubre (SRI), G. Katz (DOE), J. Howard (UTN Associates), and G. Coury (Coury Associates).

We further wish to recognize the contributions made by participants in the DOE-funded LLL-Grips "Workshop on Environmental Control Technology for The Geysers-Calistoga KGRA", that was held in Oakland, California on October 11 and 12, 1978. 50

C. Molenkamp, D. Layton, D. Ermak, P. Gudiksen, and R. Quong, all staff scientists at LLL, were helpful and willing consultants during the writing of this report. 
1. T. V. Molloy, Pacific Gas and Electric, San Francisco, Calif., Private Communication (Jan. 2, 1980).

2. D. P. Griffin and H. K. McClure, Emissions of Noncondensable Gases and Solid Materials from the Power Generating Units at The Geysers Power Plant, Pacific Gas and Electric, San Ramon, Calif., 7485.16-74 (1974).

3. D. L. Ermak, R. A. Nyholm, and P. H. Gudiksen, Imperial Valley Environmental Project: Air Quality Assessment, Lawrence Livermore Laboratory, Livermore, Calif., UCRL-52699 (1979).

4. County of Imperial Planning Department, Final Environmental Impact Report: North Brawley Ten Megawatt Geothermal Demonstration Facility, Westec Services, Inc., San Diego, Calif. (1979).

5. Conceptual Design of Commercial 50 MWe(Net) Geothermal Power Plants at Heber and Niland, California, Final Report, Bechtel Corporation, San Francisco, Calif., SAN-IR4-1 (1976).

6. J. E. Howard, VTN Associates, Irvine, Calif., Private Communication (July 5, 1979).

7. Geothermal Demonstration Program, 50 Me Power P1ant, Baca Ranch, Sandoval and Rio Arriba Counties, New Mexico, U. S. Department of Energy, Washington, D. C. DOE/EIS-0049-D (1979).

8. 0. Weres, K. Tsao, and B. Wood, Resource Technology and the Environment at The Geysers, Lawrence Berkeley Laboratory, Berkeley, Calif., LBL-5231 (1977).

9. C. J. Weinberg, "Pacific Gas \& Electric Company Geysers Geothermal Research and Development," The 1st Geothermal Environmental Seminar, Konocti Harbor Inn, Lake County, Calif. (Nov. 14 and 15, 1975).

10. G. W. Allen, H. K. McClure, and L. Semprini, Measurement of Hydrogen Sulfide Emissions Abatement at Unit 11, The Geysers, Using Iron Catalyst, December 3, 1975, Pacific Gas and Electric, San Ramon, Calif., 7485.29-75 (1975).

11. G. W. Allen, Pacific Gas and Electric, San Ramon, Calif., Private Communication (June 1979). 
12. C. J. Weinberg, "Noncondensable Gas Emissions from Power Plants--Abated and Unabated," in The Geysers Regional Air Quality Workshop, Livermore, Calif., September 28-29, 1977 (Lawrence Livermore Laboratory).

13. A. L. Aust in and A. W. Lundberg, The LLL Geothermal Energy Program, A Status Report on the Development of the Total Flow Concept, Lawrence Livermore Laboratory, Livermore, Calif. UCRL-50046-77 (1978).

14. E. J. Ennis, California Energy Commission, Sacramento, Calif., private communication (February 22, 1979).

15. D. L. Ermak, Potential Growth of Electric Power Production from Imperial Valley Geothermal Resources, Lawrence Livermore Laboratory, Livermore, Calif., UCRL-52252 (1977).

16. D. F. Snoeberger and J. H. Hill, Identification of Environmental Control Technologies for Geothermal Development in the Imperial Valley of California, Lawrence Livermore Laboratory, Livermore, Calif., UCRL-52548 (1978).

17. F. L. Tucker and L. R. Tanner, Eds., Geothermal Environmental Seminar - 18, May 9-11, 1978, Environmental Systems \& Services, Kelseyville, Calif. (1978).

18. M. Tolmasoff, Variance from Certain Hydrogen Sulfide Air Pollution Regulations at Geysers, California, ibid., p. 222 et seq.

19. R. E. Ruff, Geysers Ambient Air Quality, ibid., p. 306 et seq.

20. L. Joyce and R. A. Fontes, Air Quality as the Limiting Factor on Development of The Geysers Geothermal Resources, ibid., p. 334 et seq.

21. Geothermal Resource Investigations - East Mesa Site, Status Report, Bureau of Reclamation, United States Department of Interior, Washington, D. C. (1977).

22. Report on $\mathrm{H}_{2} \mathrm{~S}$ Air Quality and The Geysers Geothermal Development, North Sonoma County Air Pollution Control District, Healdsburg, Calif.

23. L. C. Rosen and C. R. Molenkamp, An Environmental Overview of Geothermal Development: The Geysers-Calistoga KGRA, Volume 2, Air Quality, Lawrence Livermore Laboratory, Livermore, Calif., UCRL-52496 (1978). 
24. R. K. White, R. E. Freeman, K. T. Semrau, R. E. Ruff, L. Alvanz,

L. A. Cavanagh, K. M. Clark, D. T. Dick, M. Duffey-Armstrong,

B. R. Holt, M. E. Ivory, J. L. Jones, C. A. Kroll, P. Leitner,

S. J. Maro, D. R. Myers, S. R. Pierce, J. L. Rosenbaum,

J. M. Steinberg, and B. L. Walton, Environmental Analysis for

Geothermal Energy. Development in The Geysers Regions, Vols. I and III, SRI International, Menlo Park, Calif., 5554 (1977).

25. National Geothermal Service, Sacramento Utility Plans Power Plant in Sonoma County Geysers Area (Petroleum Information Corporation, Denver, Colorado, 1979), Vol. 1, No. 21.

26. Recommended Threshold Limit Values for Chemical Substances and Physical Agents in the Workroom Environment with Intended Changes for 1975 (American Conference of Governmental and Industrial Hygienists, Cincinnati, Ohio 1975).

27. Hydrogen Sulfide, Subcomittee on Hydrogen Sulfide, Committee on Medical and Biologic Effects of Environmental Pollutants, Assembly of Life Sciences, National Research Council (National Academy of Sciences, Washington, D. C., 1977), Chapter 6.

28. R. E. Ruff and L. A. Cavanagh, 1976 Executive Summary Specialized Monitoring Services, SRI International, Menlo Park, Calif., 4351 (1977).

29. S. L. Altshuler, Ambient Air Quality at and in the Vicinity of The Geysers 1970-1975, Pacific Gas and Electric, San Ramon, Calif., 7485.25-75 (1976).

30. Federal Register 39 (U. S. Department of Labor, Occupational Safety and Health Administration, Washington, D. C., 1974), p. 23,543.

31. Handbook of Gasiffers and Gas Treatment Systems, DRAVO Corporation, Pittsburgh, Penna., FE-1772-11 (1976).

32. H. M. Castrantas, L. R. Hampshire, and B. B. Woertz, "Hydrogen Sulfide Abatement During Geothermal Steam Drilling," in Proc. Geothermal Environmental Seminar-78, May 9-11, 1978, Sacramento, California (Environmental Systems \& Services, Kelseyville, Calif.) 178 et seq. 
33. Control of Hydrogen Sulfide Emission from Geothermal Power Plants, EIC Corporation, Newton, Mass. (1977).

34. W. W. Harvey, F. C. Brown, and M. J. Turchan, Control of Hydrogen Sulfide Emission from Geothermal Power Plants, EIC Corporation, Newton, Mass. COO-2730-2 (1976).

35. C. T. Li, D. P. Alzheimer, W. A. Wilcox, G. L. Roberts, and W: F. Riemath, "Removal of Hydrogen Sulfide from Geothermal Steam," in Trans. Geothermal Resources Council Annual Meeting, Hilo, Hawaii, July 1978 (Geothermal Resources Council, 1978), Vol. 2, p. 403.

36. J. S. Wilson, J. E. King, and G. R. Bullard, Removal of Hydrogen $\sim$ Sulfide from Simulated Geothermal Brines by Reaction with Oxygen, Dow Chemical Co., COO-2797-1 (1977).

37. R. P. Hartley, Pollution Control Guidance for Geothermal Energy Development, U. S. Environmental Protection Agency, Cincinnati, Ohio, EPA-600/7-78-101 (1978).

38. J. Lazs 10, "Application of the Stretford Process for $\mathrm{H}_{2} \mathrm{~S}$ Abatement at The Geysers Geothermal Power Plant," in Proc. AIChE Intersociety Energy Conversion Conference (AIChE, 1976).

39. Comparative Process Study for Pacific Gas \& Electric Company, San Francisco, California; Hydrogen Sulfide Abatement for Geothermal Power Production Facilities, The Geysers, California, The Ralph M. Parsons Company, Pasadena; Calif.

40. H. M. Castrantas, Hydrogen Peroxide for Atmospheric Sulfide Control at Pacific Gas \& Electric's (PG\&E Co.) Geothermal Power Plant, FMC Corporation, Princeton, N.J., ICD/T-76-109 (1976).

41. R. Quong, K. G. Knauss, N.D. Stout, and L. B. Owen, An Effective $\mathrm{H}_{2} \underline{S}$ Abatement process Using Geothermal Brine Effluents, Lawrence Livermore Laboratory, Livermore, Calif., UCRL-83010 (1979).

42. J. Featherstone, Magma Power, El Centro, Calif., private communication (May 1979). 
43. R. Sung, G. Houser, G. Richard, J. Cotter, P. Weller, and E. Pulaski, Prel iminary Cost Estimates of Pollution Control Technologies for Geothermal Developments, TRW Environmental Engineering Division, Redondo Beach, Calif. (1979).

44. J. H. Hill and P. L. Phelps, Workshop on Environmental Control Technology for The Geysers-Cal istoga KGRA, Lawrence Livermore Laboratory, Calif., UCRL-52887 (1980). 
APPENDIX A

METHODOLOGY USED FOR CALCULATION OF VAPOR-LIQUID EQUILIBRIUM DISTRIBUTION OF NONCONDENSABLE GASES-- $\mathrm{H}_{2} \mathrm{~S}, \mathrm{NH}_{3}, \mathrm{AND} \mathrm{CO}_{2}$ 
This appendix presents a summary of methodology used for estimating the fractional distribution of three components-- $\mathrm{H}_{2} \mathrm{~S}, \mathrm{NH}_{3}$, and $\mathrm{CO}_{2}--$ present in geothermal fluids. The fractional distribution is estimated for the vapor and liquid phases as a function of temperature, $\mathrm{pH}$, vapor fraction, and liquid-to-condensate ratio. The methodology was patterned after a technique suggested by Dankwerts, ${ }^{A-1}$ and later implemented by PG\&E in the design of $\mathrm{H}_{2} \mathrm{~S}$ removal equipment for the ir Geysers power plant facility. $A-2, A-3$

The computational method is shown as a flowchart in Fig. A-1 and is described briefly below.

\section{STEP 1. CALCULATE FRACTIONAL DISSOCIATION}

The dissociation equilibrium constant for $\mathrm{H}_{2} \mathrm{~S}$ is determined for a given $\mathrm{pH}$ and temperature from information in Shih et al. ${ }^{\mathrm{A}-4}$ For a $\mathrm{pH}$ less than 9, the second dissociation has only a negligible influence on the equilibrium. ${ }^{\mathrm{A}-4}$ For $\mathrm{CO}_{2}$, the dissociation equilibrium constant was determined from information given by Kent and Eisenberg. ${ }^{A-5}$. Ammonia was assumed to be $100 \%$ associated under the conditions encountered in geothermal brines (Table 1). Following Shih et al., ${ }^{A-4}$ the fractional dissociation ( ) of a given species in solution may be expressed in terms of hydrogen ion concentration as follows:

$$
1-\alpha \equiv\left(H^{+}\right)^{2} /\left[\left(H^{+}\right)^{2}+K_{1}\left(H^{+}\right)+K_{1} K_{2}\right] \text {, }
$$

where $\mathrm{H}^{+}=$hydrogen ion concentration, g-ion/liter,

$K_{1}=$ the first dissociation equilibrium constant, g-ion/liter,

$K_{2}=$ the second dissociation equilibrium constant, g-ion/liter,

$\alpha=$ the fraction of a given species in solution which is dissociated.

STEP 2. CALCULATE MODIFIED HENRY'S LAW CONSTANT

Following Shih et al.,$^{A-4}$ the modified Henry's Law constant may be expressed as: .

$$
H^{\prime} \approx H(1-\alpha)
$$




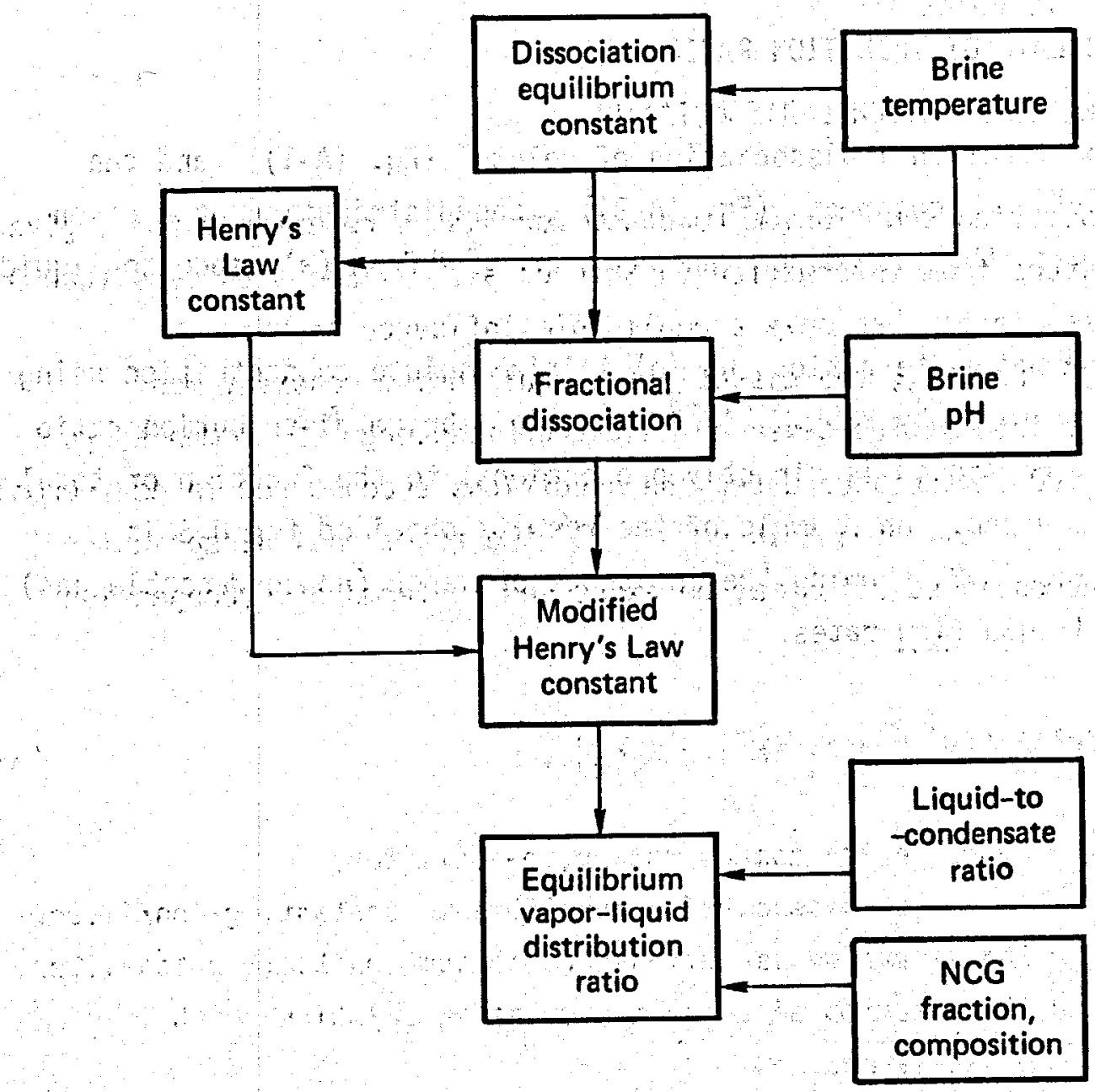

FIG. A-1. Computational method flowchart used to determine the ratio of noncondensible gas components between vapor and liquid phases in two-phase brine flows. 
where $H=$ Henry's Law constant, $\mathrm{mm} \mathrm{Hg} / \mathrm{g}$-mole-liter ${ }^{-1}$,

$H^{\prime}=$ the modified Henry's Law constant, reduced by the fraction dissociated, $\mathrm{mm} \mathrm{Hg} / \mathrm{g}-$ mole -liter $^{-1}$,

$=$ the fraction of a given species in solution which is dissociated.

Henry's Law constants for $\mathrm{H}_{2} \mathrm{~S}$ and $\mathrm{CO}_{2}$ were determined from information given in Refs. A-4 and A-5, respectively. The Henry's Law constant for $\mathrm{NH}_{3}$ was estimated from data given in Refs. A-6 and A-7.

STEP 3. CALCULATE DISTRIBUTION RATIO

Given the fractional dissociation of solute (Eq. (A-1)) and the modified Henry's Law constant (Eq. (A-2)), the distribution of a given component between the two phases can be determined from (a) vapor-to-liquid ratio,

(b) liquid-to-condensate ratio, and (c) initial solute concentration using methodology developed by $\mathrm{PG \& E} .{ }^{\mathrm{A}-2, A-3}$ The equilibrium distribution ratio between vapor and liquid is directly proportional to the fraction of total fluid which is vapor. An example of the results obtained for $\mathrm{H}_{2} \mathrm{~S}$ is presented in Fig. A-2, showing the influence of vapor (noncondensable gas) fraction and liquid flow rates.

A-4 


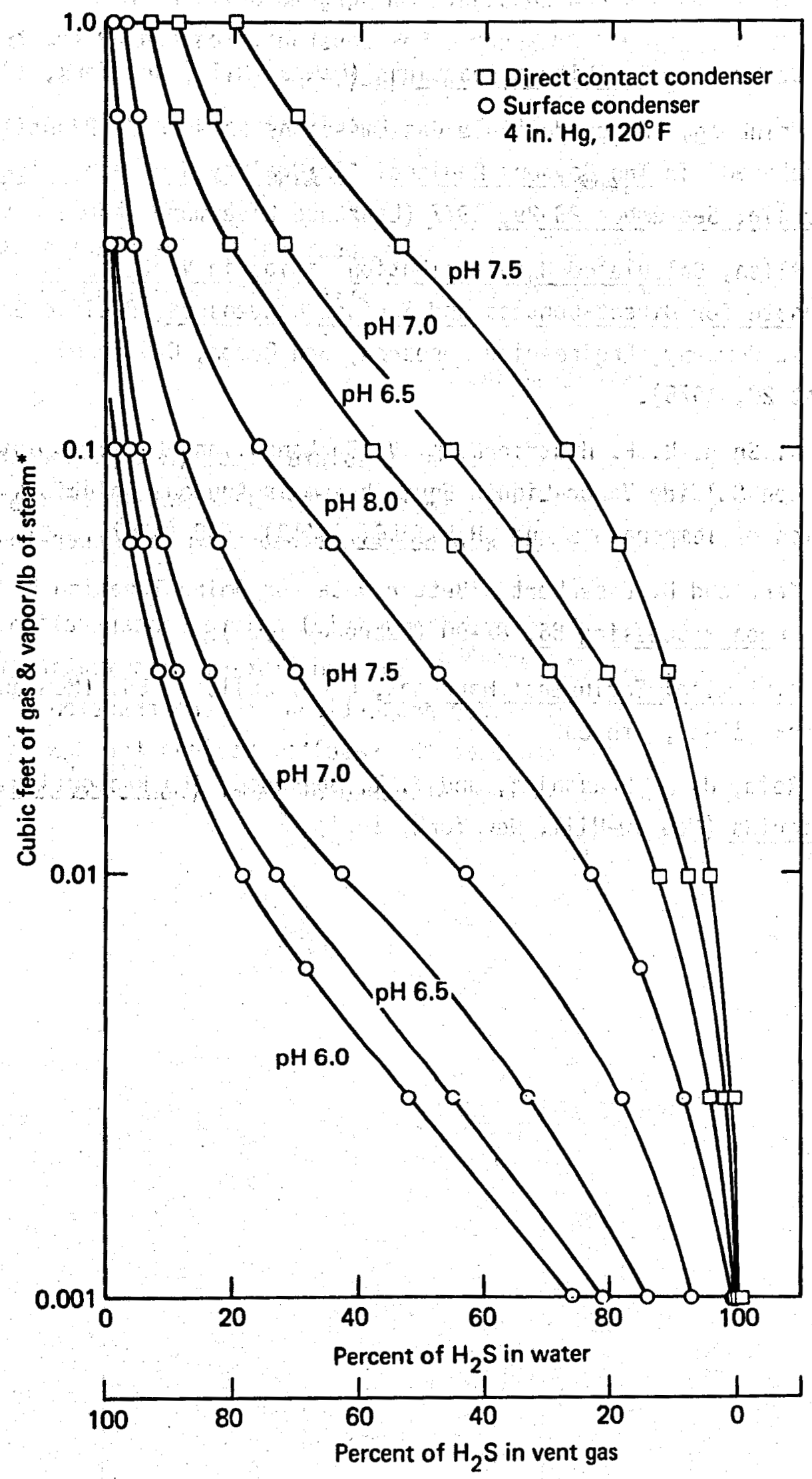

FIG. A-2. Calculated $\mathrm{H}_{2} \mathrm{~S}$ distribution ratios in vent gas for direct contact and surface condensers. $\mathrm{Cu} \mathrm{ft} / \mathrm{lb}=$ (percent by weight noncondensible gas in steam)/8. Source: Pacific Gas and Electric Company. Ref. A-3) 


\section{REFERENCES}

A-1 P. V. Dankwerts, Gas-Liquid Reactions (McGraw-Hi11, New York, 1970).

A-2 C. J. Weinberg, "Noncondensable Gas Emissions from Power Plants--Abated and Unabated" in The Geysers Regional Air Quality Workshop, Livermore, California, September 28-29, 1977 (Lawrence Livermore Laboratory).

A-3 G. W. Allen, Calculated $\mathrm{H}_{2}$ Distribution Ratios in Vent Gas and Condensate for Direct-Contact and Surface Condensers, Pacific Gas \& Electric Company, Engineering Research, San Ramon, California, (August 20, 1975).

A-4 T. T. C. Shih, B. F. Hrutfiord, K. V. Sarkanen, and L. N. Johanson, "Hydrogen Sulfide Vapor-Liquid Equilibrium in Aqueous Solutions as a Function of Temperature and pH, TAPPI 59(12), 630 (1967).

A-5 R. L. Kent and B. Eisenbert, "Better Data for Amine Treating, Hydrocarbon Processing 56, 87-90 (February 1976).

A-6 Perry's Chemical Engineers' Handbook, C. H. Chilton, Ed. (McGraw-Hi11, New York, 1964), 4th ed.

A-7 R. C. Reid, J. M. Prausnitz, and T. K. Sherwood, The Properties of Gases and Liquids (McGraw-Hill, New York, 1977). 
APPENDIX B

COST DATA 
Most of the $\mathrm{H}_{2} \mathrm{~S}$ abatement systems have been utilized only on a limited scale or are still in experimental or pilot plant stages. The costs, therefore, must be considered preliminary judgments based primarily on the use of the technologies in related industries. ${ }^{\mathrm{B}-1}$

Published data on costs for $\mathrm{H}_{2} \mathrm{~S}$ control methods are limited or in some cases non-existent. Operation and maintenance cost estimates are based on a control system with stable operation and do not include major upset conditions or extended repair periods. ${ }^{B-1}$

The costs have been standardized to the dollar value at the end of the second quarter, 1977. Capital costs have been amortized by the capital recovery factor over the estimated life of the control technology equipment at an annual interest rate of $8 \%{ }^{\mathrm{B}-1}$

Detailed cost estimates are given for four candidate control technologies:

Stretford process

Iron-Catalyst process

EIC process

Dow 0xygenation process.

These cost estimates, which follow, have been excerpted from Ref. B-1. 
Stretford Process

\section{Costs}

Stretford process cost estimates are based on the process currentiy being designed for installation on the $117.5 \mathrm{MW}$, unit 14 power plant at the Pacific Gas and Electric Geysers facility in 1978 (Lasz10, 1976).

The installed capital cost of approximately $\$ 2,432,000$ was used as a basis for the Stretford cost estimates presented herein (Laszio, 1976). The Geysers unit 14 will produce electrical power from a vapor-dominated resource with the following operating conditions:

- Steam quality: $180^{\circ} \mathrm{C}\left(355^{\circ} \mathrm{F}\right)$

\section{. 7.8 atm (114 psia)}

: $220 \mathrm{ppm}$ average hydrogen sulfide concentration

$1200 \mathrm{Btu} / \mathrm{Ib}$

- Stean flow rate: $907,000 \mathrm{~kg} / \mathrm{hr}(2,000,000 \mathrm{lb} / \mathrm{hr})$

- Scrubbing efficiency: 99 percent, or greater

All capital costs for the Stretford process include the differential investment required for a surface condenser in lieu of a direct contact condenser. Capital costs for units with hydrogen sulfide concentration or steam flow rates differing from those given for the Geysers unit 14 base case can be computed utilizing the-following formulas obtained from Mark Griebe of the Ralph M. Parsons Company (Griebe, 1977):

$I A=I B\left(\frac{S A}{S B}\right) 0.4$ for: $0.5<S A<5$ metric tons of sulfur per day $I A=I B\left(\frac{S A}{S B}\right) 0.5$ for $5<S A<250$ metric tons of sulfur per day

$S A$ : metric tons of sulfur produced per day in the desired case: $S B=$ metri $=$ tons of sulfur produced per day by the base case (The Geysers unit 14) Stretford process.
$I$ - Capital investment for the desired or base (A or B) Stretford. process

Based on the above equations, the capital cost for a stretford unit is assumed to be exponentially dependent upon the quantity of elemental sulfur produced. Ninety percent of the totai sulfur entering the power plant as hydro-? gen sulfide is assumed to be removed by the stretford process. 
The following assumptions were used to estimate the annual capital and operating/ma intenance costs for a Stretford unit:

- Amortization period: 15 years (SRI, 1977)

- Maintenance materiails: 2 percent of the installed capital cost (Griebe, 1977)

- Maintenance labor: 10 percent downtime, requiring a two-man maintenance crew, earning approximately $\$ 30$ per hour per person

- Electrical power usage: 66 operating BHP per metric ton of sulfur produced per day (Griebe, 1977)

- Chemical cost: $\$ 35$ per metric ton of sulfur produced per day (Griebe, 1977)

- Sulfur credit: $\$ 20$ per metric ton

- Construction site: The Geysers

The accepted market value of commercial grade elemental sulfur is approximately $\$ 40$ per metric ton. However, the market value is dependent upon the demand in the vicinity of the geothermal site, and in some areas could be as low as $\$ 3$ to $\$ 4$ per metric ton (Griebe, 1977). Since geothermal sites are likely to be located in remote areas, a market value of $\$ 20$ per ton was used to compensate for transportation and other costs. A credit for the elemental sulfur produced by the Stretford process was deducted from the annual operation and maintenance cost.

The Stretford annual costs as a function of steam flow rates ranging from $100,000 \mathrm{~kg} / \mathrm{hr}$ to $907,000 \mathrm{~kg} / \mathrm{hr}$ for a constant hydrogen sulfide concentration are presented in Table 3: Costs as a function of hydrogen sulfide concentration varying between $220 \mathrm{ppm}$ and $10,000 \mathrm{ppm}$ at a constant steam flow rate are given in Table 4. Table 3 is based on a hydrogen sulfide concentration of $220 \mathrm{ppm}$, equivalent to that normally found at The Geysers. Table 4 is based on a steam flow rate of $907,000 \mathrm{~kg} / \mathrm{hr}$, equivalent to that of The Geysers 117.5 MW unit 14. Normalized total, capital, and operation/maintenance annual costs, based on the estimates given in Table 3 and 4 , are presented in Figures 8,9 , and 10. The costs are based specifically on the design conditions for The Geysers unit 14 power plant and do not apply to geotherrial energy conversion systems in general. At other geothèrmal sites, greater or lesser quantity of steam may be required to produce the same amount of electrical energy. Since the cost of a Stretford process is a function of the sulfur mass flow rate, costs will vary from those presented for other geothermal applications.

Figure 8 gives the costs, in dollars per $\mathrm{kg} / \mathrm{hr}$ of steam, for steam flow rates varying from $100,000 \mathrm{~kg} / \mathrm{hr}$ to $907,000 \mathrm{~kg} / \mathrm{hr}$ and a hydrogen sulfide concentration of $220 \mathrm{ppm}$. Costs, in mills per $\mathrm{kWH}$, for power generation capacities ranging from $12.95 \mathrm{MW}$ to $117.5 \mathrm{MW}$ and a hydrogen sulfide concentration of $220 \mathrm{ppm}$ are presented in Figure 9. The dependency of the Stretford process costs, in mills per KWH, on hydrogen sulfide concentration in the steam is shown in Figure 10. Costs were estimated for hydrogen sulfide concentrations ranging from $220 \mathrm{ppm}(0.022$ percent) to $10,000 \mathrm{ppm}$ (1.0 percent). A cost estimate for a 5.0 percent $(50,000 \mathrm{pFm})$ hydrogen sulfjce concentration ind $907,000 \mathrm{~kg} / \mathrm{hr}$ steam flow rate is not presented because the resultant sulfur production rate is beyond the valid range of the cost equation. 
TABLE 3. STRETFORD ANNUAL COSTS VS. STEAM FLOW RATE. (220 ppm Ho

\begin{tabular}{|c|c|c|c|c|}
\hline \multirow[b]{2}{*}{ Costs $(\$)$} & \multirow[b]{2}{*}{100,000} & \multicolumn{2}{|c|}{ Steam Flow Rate $(\mathrm{kg} / \mathrm{hr})$} & \multirow[b]{2}{*}{907,000} \\
\hline & & 400,000 & 700,000 & \\
\hline Annual Capital & 122,800 & 213,700 & 267,400 & 284,200 \\
\hline $\begin{array}{l}\text { Maintenance Material } \\
\text { Maintenance Labor } \\
\text { Electrical Power } \\
\text { Chemicals } \\
\text { Sulfur Credit }\end{array}$ & $\begin{array}{r}21,800 \\
50,000 \\
7,200 \\
5,500 \\
-3,100\end{array}$ & $\begin{array}{r}36,600 \\
50,000 \\
28,700 \\
21,800 \\
-12,500\end{array}$ & $\begin{array}{r}45,800 \\
50,000 \\
50,200 \\
38,200 \\
-21,800\end{array}$ & $\begin{array}{r}48,700 \\
50,000 \\
53,500 \\
44,500 \\
-25,400\end{array}$ \\
\hline Total $0 \& M$ Cost & 80,600 & 124,600 & 162,400 & 176,300 \\
\hline Total Annual Cost & 203,400 & 338,300 & 429,800 & 460,500 \\
\hline
\end{tabular}

NOTE: *Based on The Geysers unit 14 steam flow rate (Lasz10, 1976)

TABLE 4. STRETFORD ANNUAL COSTS VS. HYDROGEN SULFIDE CONCENTRATION IN STEAM $907,000 \mathrm{~kg} / \mathrm{hr}$ STEAM FLOW RATE

\begin{tabular}{lrrr}
\hline & & Ppm $\mathrm{H}_{2} \mathrm{~S}$ & \\
\hline Costs (\$) & 220 & 2000 & 10,000 \\
\hline Annual Capital & 284,200 & 857,400 & $1,916,700$ \\
& & 146,800 & 328,100 \\
Maintenance Material & 48,700 & 50,000 & 50,000 \\
Maintenance Labor & 50,000 & 531,900 & $2,658,300$ \\
Electrical Power & 58,500 & 405,300 & $2,025,500$ \\
Chemicals & 44,500 & $-231,600$ & $-1,157,400$ \\
Sulfur Credit & $-25,400$ & 902,400 & $3,904,500$ \\
Total O \& M Cost & 176,300 & $1,759,800$ & $5,821,200$ \\
Total Annual Cost & 460,500 & & \\
\hline
\end{tabular}

NOTE: A $50,000 \mathrm{ppm}$ ( 5 s by weight). $\mathrm{H}_{2} \mathrm{~S}$ concentration at the given steam flow rate, results in a sulfur production rate beyond the range of this cost estimate. 


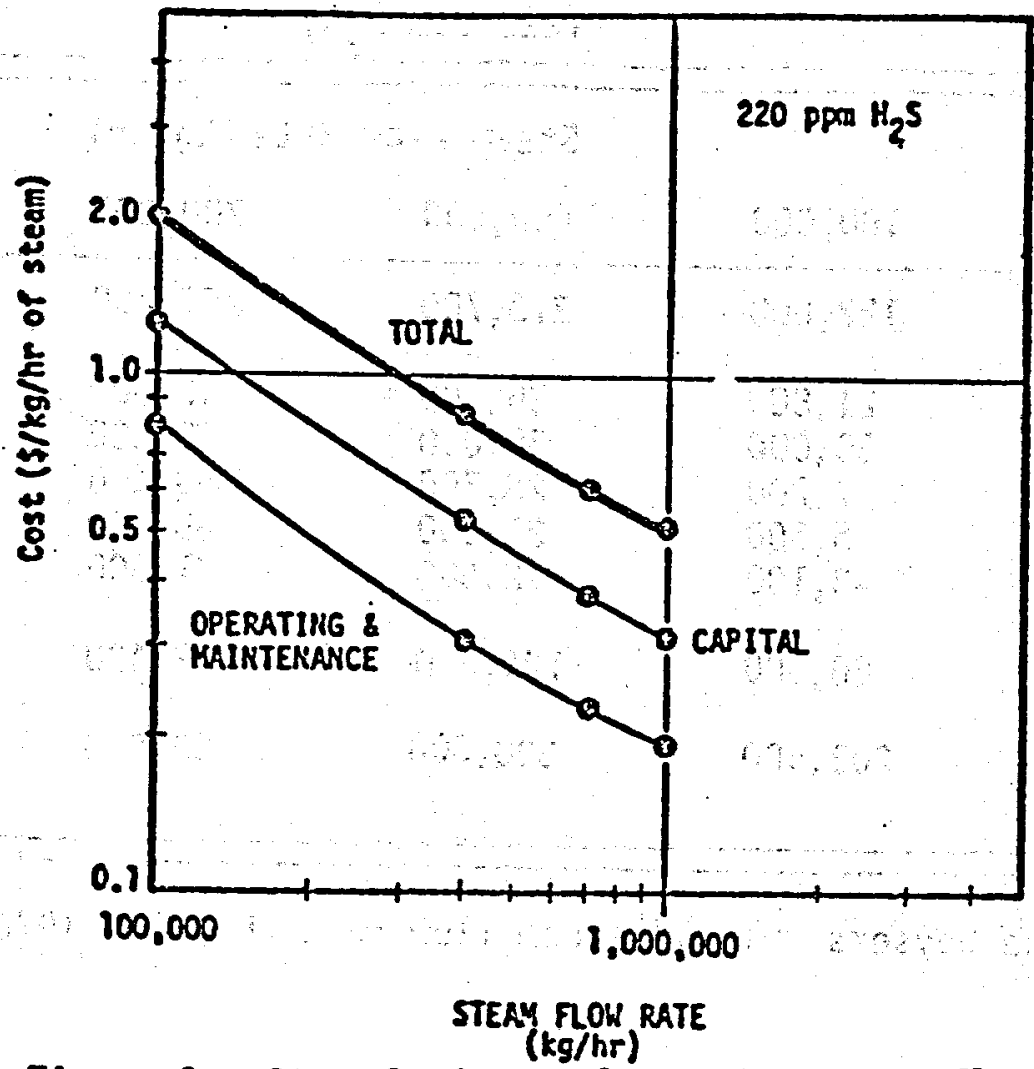

Figure 8. Stretford annual cost vs steam flow rate

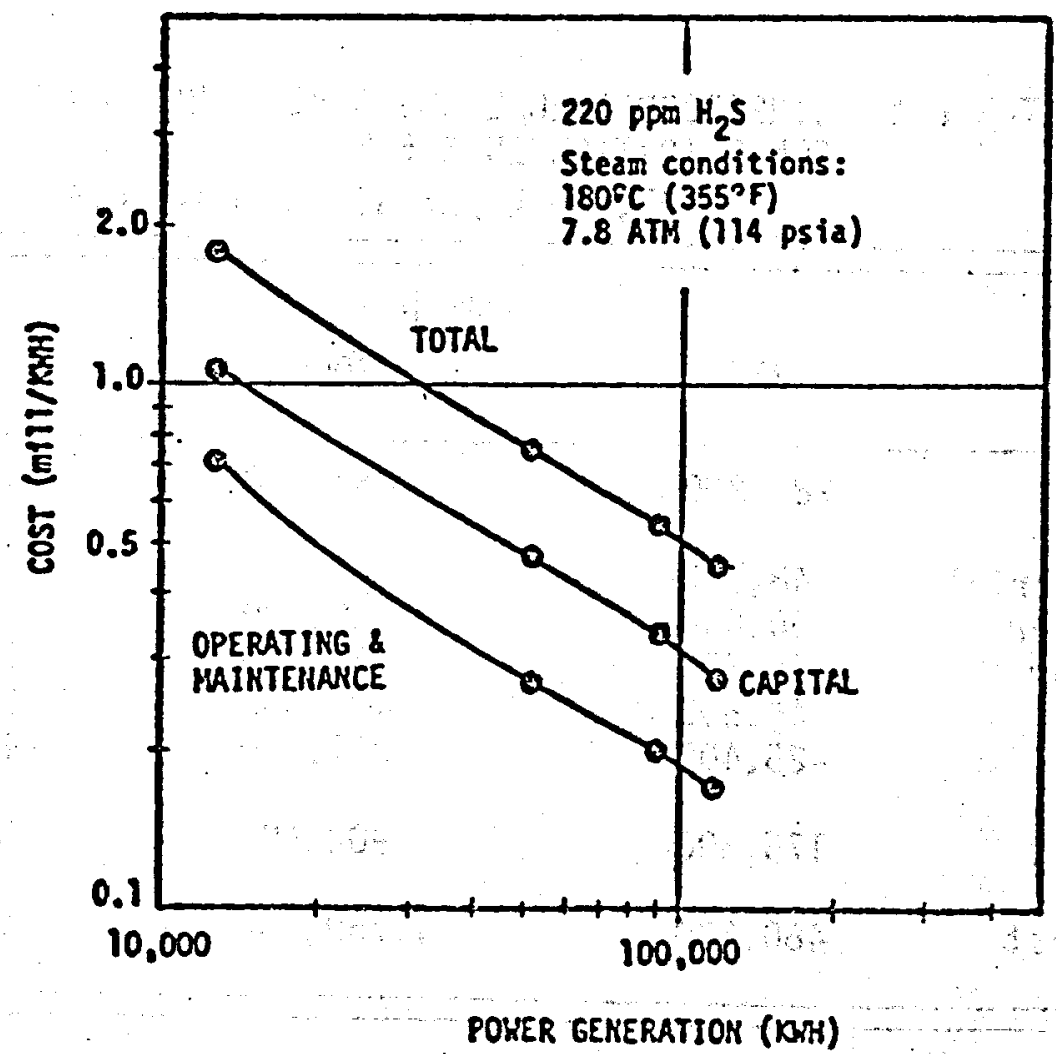

Figure 9. Stretford annual cost vs porer generation 


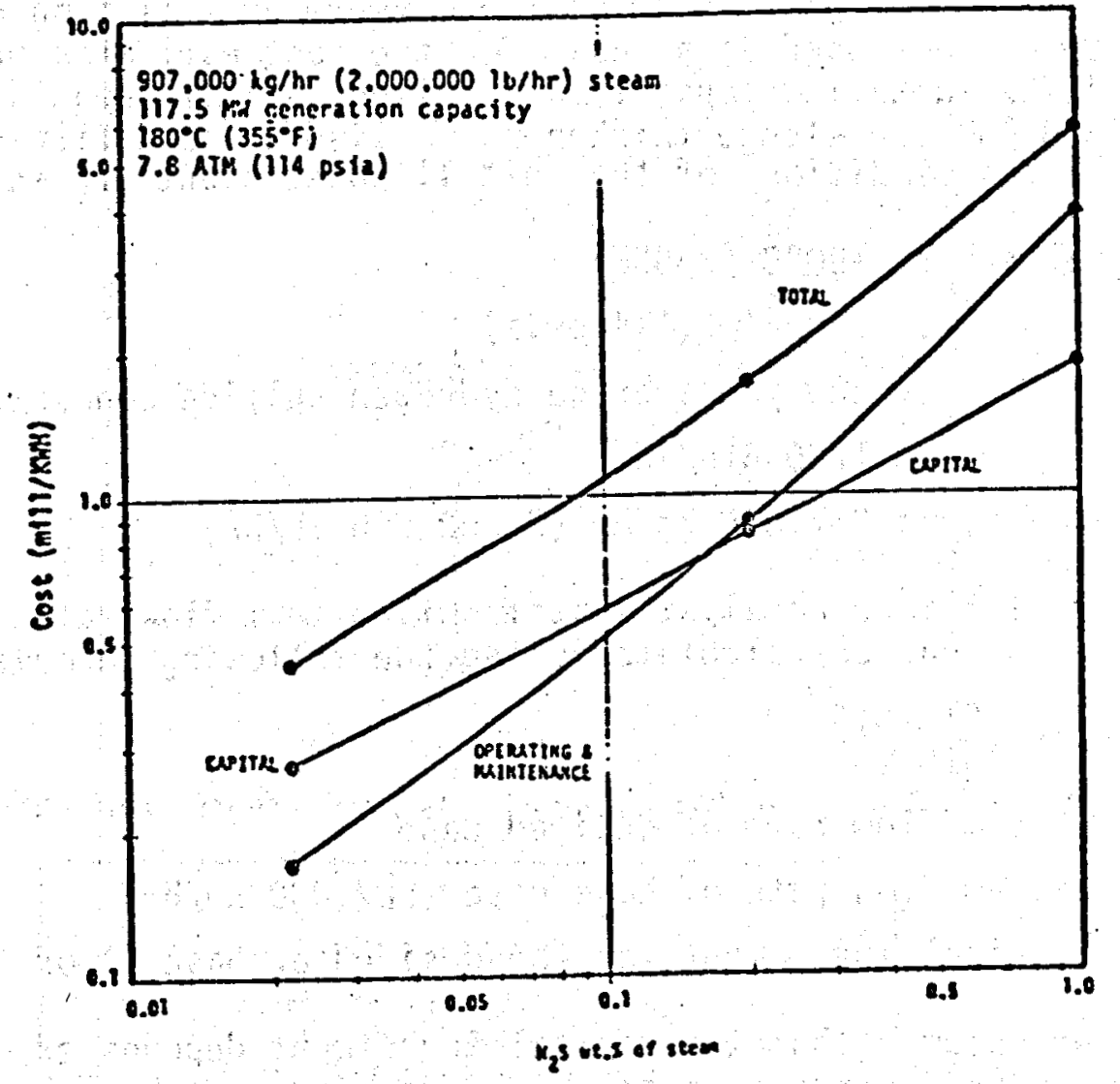

Figure 10. Stretford annual cost $\mathrm{vs}_{2} \mathrm{~S}$ concentration 
(The cost analysis for this process does not include the peroxide supplement currently used at The Geysers. If the peroxide modification was taken into account, the cost estimates would be significantly higher. See note below Table 13 of main text.) - F.B.S.

The installed capital cost of The Geysers unit 11 iron catalyst sys.tem is $\$ 1,718,000$ and was used as a basis for the cost estimates presented (Laszlo, 1976). The installed capital cost includes a differential estimated investment of $\$ 300,000$ for sludge thickeners in lieu of sand filters (Galeski, 1977). The operating conditions of the unit 11 power plant are as follows:

- Steam quality : $180^{\circ} \mathrm{C}\left(355^{\circ} \mathrm{F}\right)$

: 7.8 atm (114 psia)

: $220 \mathrm{ppm}$ average hydrogen sulfide concentration

: $1200 \mathrm{Btu} / \mathrm{lb}$

- Steam flow rate : $907,000 \mathrm{~kg} / \mathrm{hr}(2,000,000 \mathrm{lb} / \mathrm{hr})$

Capital costs for iron catalyst systems with steam flow rates differing from that given above can be calculated using the following formula:

$$
\begin{aligned}
& I A=I B\left(\frac{S T A}{S T B}\right) 0.6 \\
& \text { STA }=\text { Steam flow rate of desired case } \\
& \text { STB }=\text { Steam flow rate of base case }(907,000 \mathrm{~kg} / \mathrm{hr}) \\
& I=\text { Capital investment for the desired or base }(A \text { or } B) \text { case. }
\end{aligned}
$$

The above equation assumes that the capital investment depends exponentially on the steam flow rate according to the Williams sixth-tenths rule (Hesketh, 1973). The cost of the iron catalyst system is a function of the cooling water/condensate flow rate, which is directly proportional to the steam flow rate. Therefore, the steam flow rate is an acceptable variable in the cost equation. Capital costs were assumed not to be affected by variations in hydrogen sulfide concentration. Operation and maintenance costs for electrical power and chemical usage were assumed to be linearly dependent upon: steam flow rate (with constant hydrogen sulfide concentration) and hydrogen sulfide concentration (with constant steam flow rate). Operation and maintenance costs are difficult to estimate due to the operational problems encountered at The Geysers (Allen, 1977).

The following assumptions were used for the iron catalyst annual capital and operation/maintenance cost estimates:

- Amortization period: 15 years

- Maintenance materials: 1 percent of the installed capital cost

- Maintenance labor: 10 percent down time, requiring a two man crew, earning approximately $\$ 30$ per hour per person 
- Electrical power usage: $68 \mathrm{KW}$ per hour (Galeski, 1977)

- Ferric sulfate usage: $0.5 \mathrm{~kg}$ ferric sulfate per $\mathrm{kg}$ of hydrogen sulfide, with a loss factor of 20 percent (Lasz10, 1976)

- Ferric sulfate cost: $\$ 0.05$ per lb or $\$ 0.11 / \mathrm{kg}$ (Galeski, 1977)

- Removal efficiency: 90 to 92 percent

Construction site:

The Geysers

The annual costs for the iron catalyst system as a function of steam flow rate ranging from $100,000 \mathrm{~kg} / \mathrm{hr}$ to $907,000 \mathrm{~kg} / \mathrm{hr}$ for a constant hydrogen sulfide. concentration, and as a function of hydrogen sulfide concentration varying from $220 \mathrm{ppm}$ to $50,000 \mathrm{ppm}$ for a constant steam flow rate, are given in Tables 5 and 6 , respectively. Table 5 is based on a hydrogen sulfide concentration of $220 \mathrm{ppm}$, equivalent to that normally found at The Geysers. Table 6 is based on a steam flow rate of $907,000 \mathrm{~kg} / \mathrm{hr}$, equivalent to that of The Geysers $110 \mathrm{MW}$ unit 11 . Based on these tables, normalized total, capital and operation/ma intenance annual costs are shown in Figures 12,13 and 14 . Generation capacities are based specifically on the operating conditions for The Geysers unit 11 power plant and cannot be applied to geothermal energy conversion systems in genera1. Figure 14 shows the costs, in mills per $X W H$, for a $907,000 \mathrm{~kg} / \mathrm{hr}$ steam flow rate and hydrogen sulfide concentrations varying from $220 \mathrm{ppm}(0.022$ percent $)$ to $50,000 \mathrm{ppm}$ (5.0 percent).

TABLE 5. IRON CATALYST ANNUAL COST VS. STEAM FLOW RATE. (220 pDM H/S)

\begin{tabular}{|c|c|c|c|c|}
\hline \multirow[b]{2}{*}{$\operatorname{Costs}(\$)$} & \multirow[b]{2}{*}{100,000} & \multicolumn{2}{|c|}{ Steam Flow Rate $(\mathrm{kg} / \mathrm{hr})$} & \multirow[b]{2}{*}{$907,000^{*}$} \\
\hline & & 400,000 & 700,000 & \\
\hline Annual Capital & 53,400 & 122,800 & 171,800 & 200,700 \\
\hline $\begin{array}{l}\text { Maintenance Material } \\
\text { Maintenance Labor } \\
\text { Electrical Power } \\
\text { Chemicals }\end{array}$ & $\begin{array}{r}4,600 \\
50,000 \\
2,100 \\
10,200\end{array}$ & $\begin{array}{r}10,500 \\
50,000 \\
8,400 \\
40,800\end{array}$ & $\begin{array}{l}14,700 \\
50,000 \\
14,700 \\
71,300\end{array}$ & $\begin{array}{l}17,180 \\
50,000 \\
19,000 \\
92,400\end{array}$ \\
\hline Total $0 \& M$ cost & 66,900 & 109,700 & 150,000 & 178,600 \\
\hline Total Annual Cost & 120,300 & 232,500 & 322,500 & 379,300 \\
\hline
\end{tabular}

NOTE: - Based on The Geysers unit 11 stean flow rate (Laszlo, 1976) 
TABLE 6. IRON CATALYST ANNUAL COST VS. HYDROGEN SULFIDE CONCENTRATION IN STEAY. (907.000 $\mathrm{kg} / \mathrm{hr}$ STEAM FLOH RATE)

\begin{tabular}{|c|c|c|c|c|}
\hline Costs $(\$)$ & 220 & $2000^{\circ}$ & 10,000 & 50,000 \\
\hline Annual Capital & 200,700 & 200,700 & 200,700 & 200,700 \\
\hline $\begin{array}{l}\text { Maintenance Material } \\
\text { Maintenance Labor } \\
\text { Electrical Power } \\
\text { Chemicals }\end{array}$ & $\begin{array}{l}17,200 \\
50,000 \\
19,000 \\
92,400\end{array}$ & $\begin{array}{r}17,200 \\
50,000 \\
19,000 \\
923,800\end{array}$ & $\begin{array}{r}17,200 \\
50,000 \\
19,000 \\
4,199,800\end{array}$ & $\begin{array}{r}17,200 \\
50,000 \\
19,000 \\
21,999,800\end{array}$ \\
\hline Total $0 \& M$ Cost & 178,600 & $1,010,000$ & $4,266,000$ & $21,086,000$ \\
\hline Total Annual Cost & 378,300 & $1,210,700$ & $4,486,700$ & $21,286,700$ \\
\hline
\end{tabular}

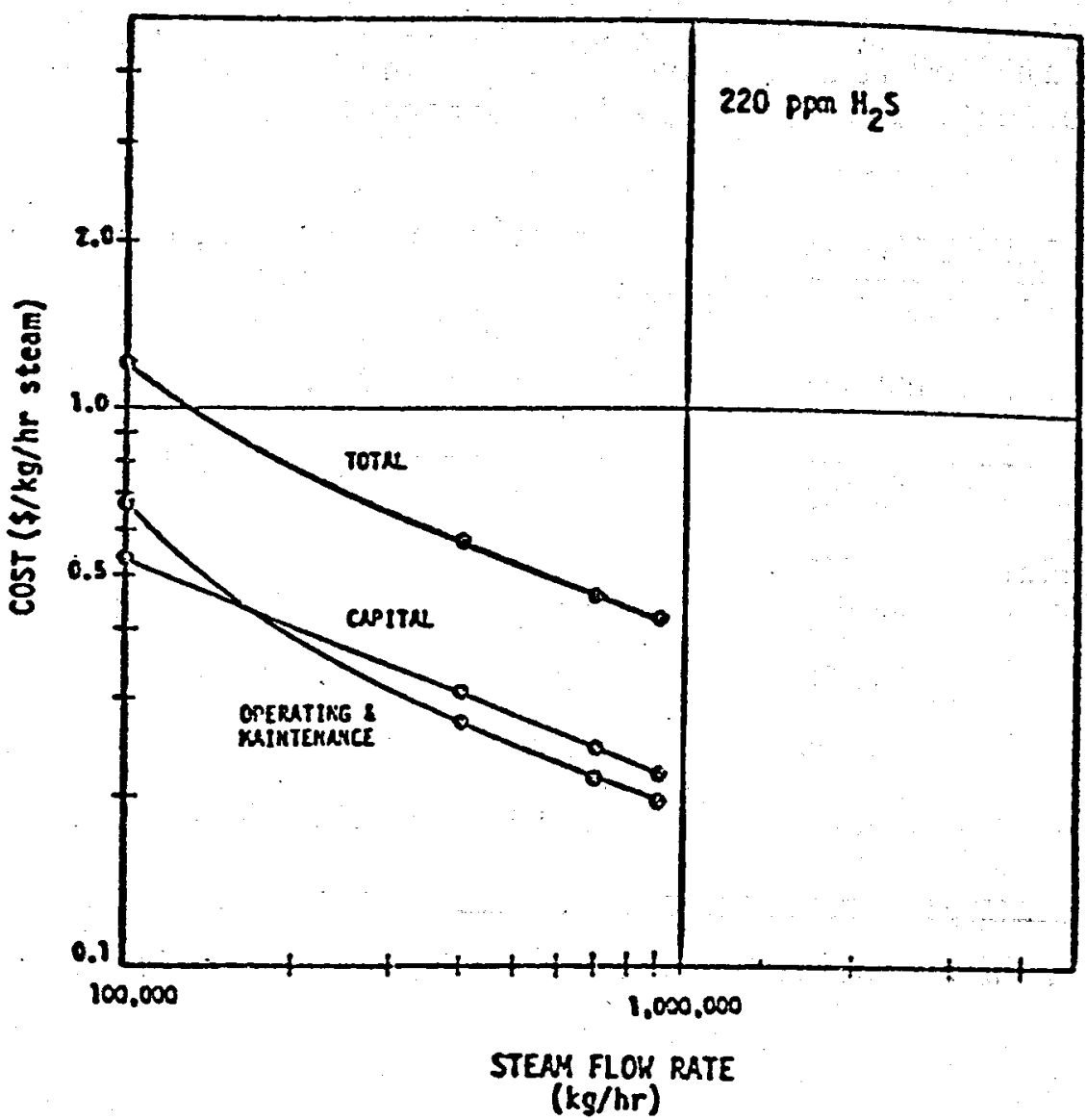

Figure 12. Iron catalyst cost vs. steam flow rate 


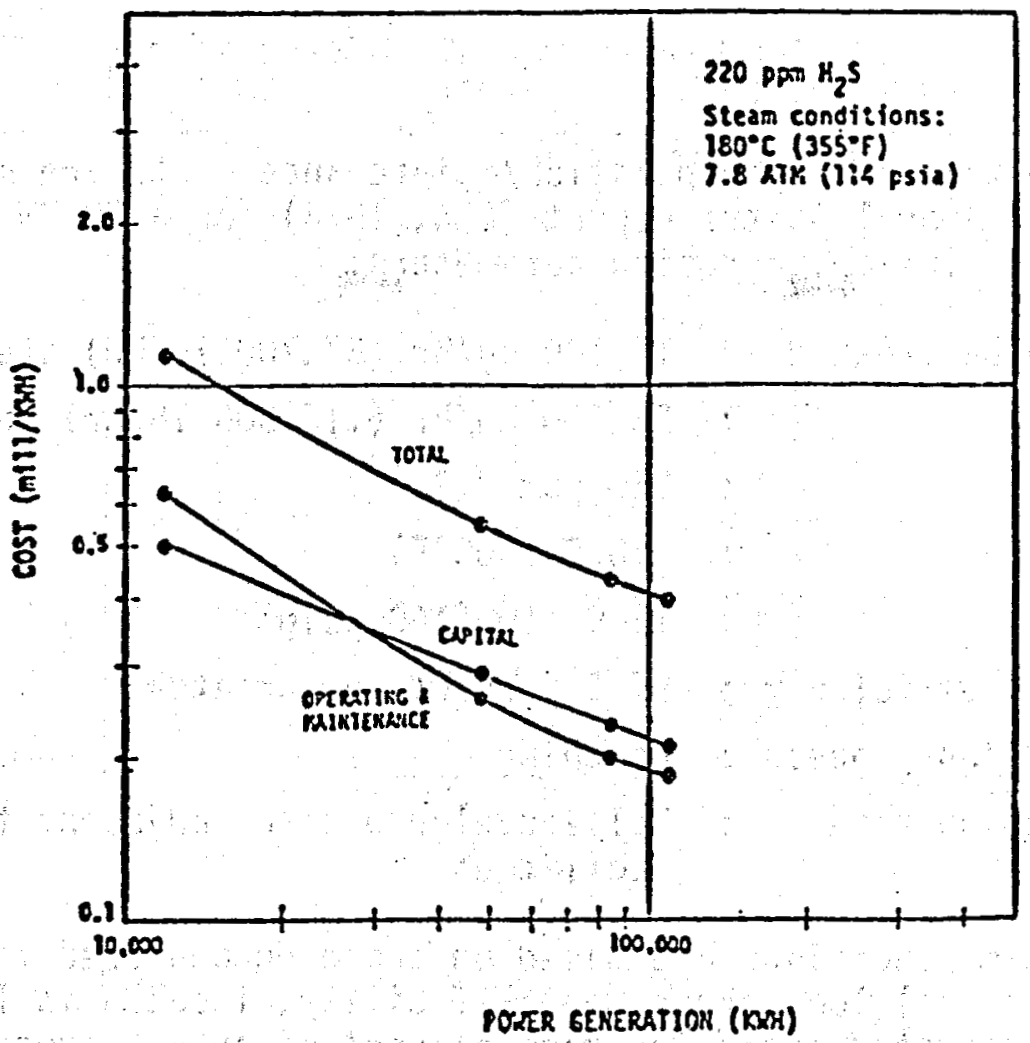

Figure 13. Iron catalyst annual cost vs power generation

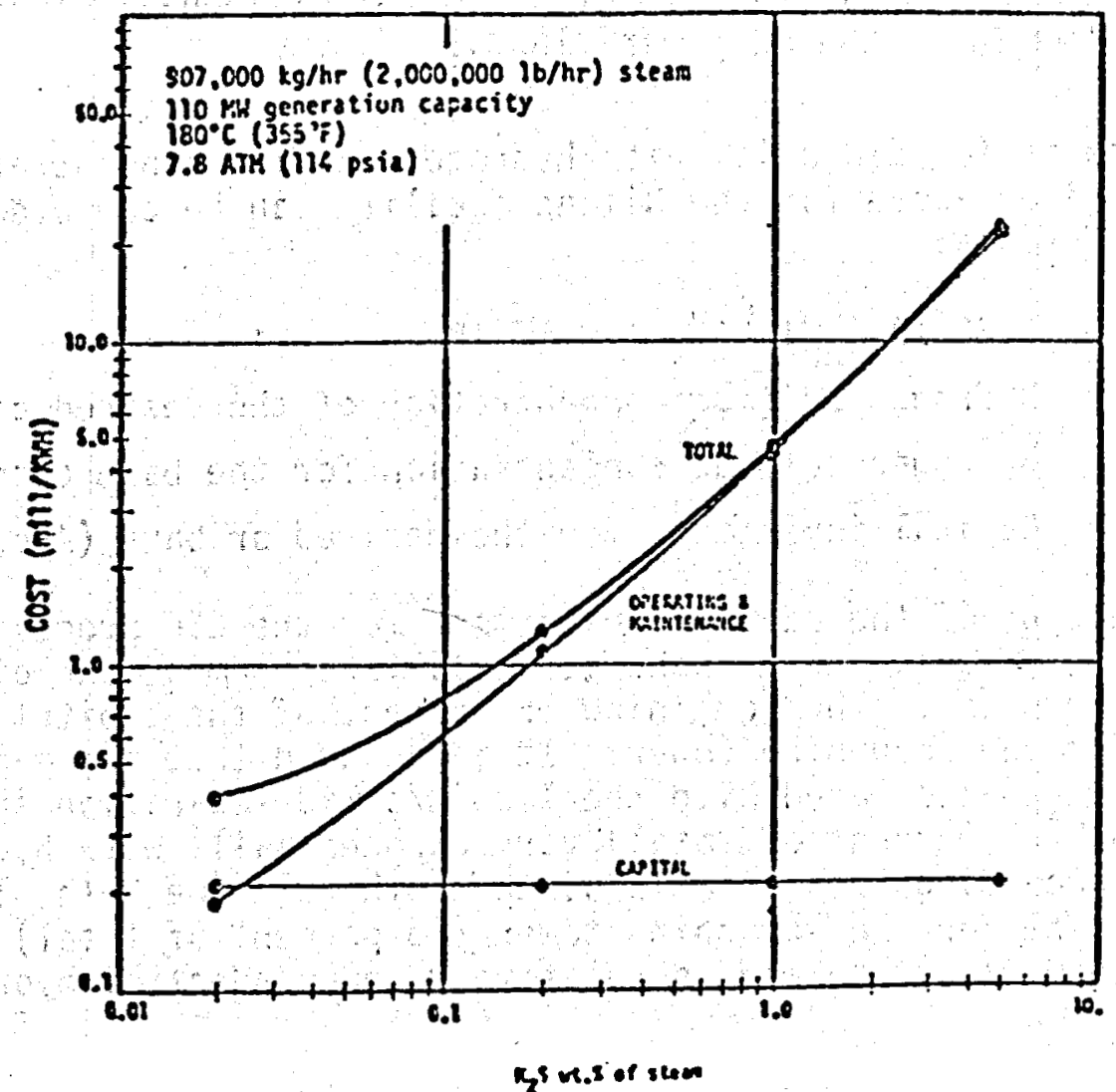

Figure 14. Iron catzlyst annual cost vs. $\mathrm{H}_{2} \mathrm{~S}$ concentration 
Installed capital cost and operation/maintenance costs are summarized in the EIC Corporation Annual Status Report (EIC, 1976) for a 50 MW geothermal power plant with the following design parameters:

Steam to be treated : $\begin{aligned} & 17,100 \mathrm{~kg} / \mathrm{hr}(37,700 \mathrm{lb} / \mathrm{hr}) \text { steam } \\ : & 53,900 \mathrm{~kg} / \mathrm{hr}(118,900 \mathrm{lb} / \mathrm{hr}) \text { jnerts } \\ : & 830 \mathrm{ppm} \mathrm{H} / 2 \\ : & 150^{\circ} \mathrm{C}\left(300^{\circ} \mathrm{F}\right) \\ : & 11.9 \mathrm{~atm}(160 \mathrm{psig})\end{aligned}$
Scrubbing efficiency : 97.5 percent, or greater
Regeneration process : Leaching
Construction site : Well-developed site, adjacent to existing
facilities

The above steam conditions are based on those encountered for vent gases at the Niland geothermal loop experimental facility, located in Imperial Valley, California. The estimated installed capital cost of an EIC process removing hydrogen suifide from steam utilized in a $50 \mathrm{MW}$ geothermal power plant, operating with the above conditions, is $\$ 4,400,000$ (EIC, 1976). Total annual operating cost, including capital, is given in the EIC Annual Status Report as 1.5 mills per KWH for a $500 \mathrm{MW}$ power plant.

Capital costs for EIC units with hydrogen sulfide concentrations differing from that given above for the Niland facility can be computed utilizing the following formula:

$$
\begin{aligned}
& I A=0.85 \mathrm{IB}\left(\frac{\mathrm{HA}}{\mathrm{HB}}\right) 0.6+0.15 \mathrm{IB} \\
& \mathrm{HA}=\text { Hydrogen sulfide concentration of the desired case } \\
& \mathrm{HB}=\text { Hydrogen sulfide concentration for the base case }(830 \mathrm{ppm}) \\
& I=\text { Capital investment for the desired or base }(A \text { or } B) \text { case }
\end{aligned}
$$

Eighty-five percent of the capital investment for the EIC process involves reactors, tanks, vessels, heat exchangers, filters, pumps, and other associated process equipment. The remaining 15 percent of the capital investment is allocated for the scrubbing tower. It is assumed that the capital investment for equipment associated with the iiquid/solid separation and regeneration operations ( 85 percent of tota 1) vary exponentially with hydrogen sulfide concentration according to Hilliam's sixth-tenth rule (Hesketh, 1973). The capital investment for the scrubbing tower ( 15 percent of total) is assumed to depend upon steam flow rate and is relatively independent of hydrogen sulfide concentration. 
Assumptions used to estimate the annual capital and operation/maintenance costs for an EIC'unit are (EIC, 1976):

- Amortization period: 10 years

- Maintenance materials: 2 percent of the installed capital cost

- Maintenance labor: 4 operators at $\$ 18,000$ per year per person

1 maintenance man at $\$ 20,000$ per year

I supervisor at $\$ 22,000$ per year

- Electrical power usage: 2,200,000 KWH per year

- Water usage: 10,000,000 gallons $\left(37.85 \times 10^{6}\right.$ liters $)$ per year at $\$ 0.50$ per 1000 gallons (3785 liters)

- Chemical and process materials:

sulfuric acid - 300 tons (273 metric tons) per year at $\$ 33$ per ton ( $\$ 36.30 /$ metric ton)

limestone - 250 tons (227 metric tons) per year at $\$ 8$ per ton (\$8.80/metric ton)

precipitated copper - 37.5 tons ( 34 metric tons) per year at $\$ 1600$ per ton (\$1760/metric tori)

detinned scrap - 45 tons (41 metric tons) per year at $\$ 200$ per ton (\$220/metric ton)

miscellaneous - $\$ 19,000$

The EIC process annual costs for a $50 \mathrm{MW}$ and $500 \mathrm{MW}$ geothermal power plant are given in Table 7. The annual costs for a $50 \mathrm{MW}$ power plant with hydrogen sulfide steam concentrations varying from $830 \mathrm{ppm}$ to $50,000 \mathrm{ppm}$ are presented in Table 8. The cost estimates given in Table 7 were derived from the basic EIC data given for a 50 MW power plant with a hydrogen sulfide concentration in the steam of $830 \mathrm{ppm}$. Capital costs as a function of increased hydrogen sulfide concentration were calculated, based on the formula given previously. Operation and maintenance costs for electrical power, water, chemicals, and process materials were assumed to increase linearly with an increase in hydrogen sulfide concentration. Normalized total, capital and operation/maintenance annual costs given in Tables 7 and 8 are shown in Figures 17, 18 and 19. The cost estimates presented for the EIC process were developed from the specific set of operating conditions previously outlined, and may not necessarily apply to geothermal resources with different operating conditions.

Figure 17 gives the cost, in dollars per $\mathrm{kg} / \mathrm{hr}$, for steam flow rates of $71,000 \mathrm{~kg} / \mathrm{hr}$ and $7,100,000 \mathrm{~kg} / \mathrm{hr}$ (corresponding to $50 \mathrm{MW}$ and $500 \mathrm{MW}$ ) and a hydrogen sulfide concentration of $830 \mathrm{ppm}$. Costs, in mills per KWH, for power generation capacities ranging between $50 \mathrm{MW}$ and $500 \mathrm{MW}$ and a hydrogen sultide: concentration of $830 \mathrm{ppm}$ are given in Figure 1.8. Costs, in mills per KWH, estimated for a generating capacity of $50 \mathrm{MW}$ and hydrogen sulfide concentrations from $830 \mathrm{ppm}(0.033$ percent) to $50,000 \mathrm{ppm}$ ( 5.0 percent), are showin in Figure 19. 
TABLE 7. EIC ANNUAL COST FOR $50 \mathrm{MW}$ AND $500 \mathrm{MW}$ PLANTS (EIC, 1976). $830 \mathrm{PPH} \mathrm{H}_{2} \mathrm{~S}$

\begin{tabular}{lrc}
\hline & \multicolumn{1}{c}{ Plant Generating Capacity (MW) } \\
\hline Costs $(\$)$ & 50 & 500 \\
\hline Annual Capital & 655,700 & $3,725,800$ \\
Maintenance Material & 88,000 & - \\
Maintenance Labor & 114,000 & - \\
Electrical Power & 88,000 & - \\
Water & 5,000 & - \\
Chemicals and Process Material & 100,000 & $3,413,000 *$ \\
Total 0 \& M Cost & 395,000 & $7,138,800$ \\
Total Annual Cost & $1,050,700$ & \\
\hline
\end{tabular}

NOTE: * Derived from EIC cost data for total annual operating costs (EIC, 1976)

TABLE 8. EIC ANNUAL COST FOR 50 MW PLANT VS. HYDROGEN SULFIDE CONCENTRATION IN STEAM

\begin{tabular}{|c|c|c|c|c|}
\hline Costs (\$) & 830 & $\begin{array}{c}\mathrm{H}_{2} \mathrm{~S} \mathrm{ppm} \\
2000\end{array}$ & 10,000 & 50,000 \\
\hline Annual Capital & 655,700 & $1,040,300$ & $2,573,000$ & $6,613,700$ \\
\hline $\begin{array}{l}\text { Maintenance Material } \\
\text { Haintenance Labor } \\
\text { Electrical Power } \\
\text { Water } \\
\text { Chemicals and Procéss } \\
\text { Material }\end{array}$ & $\begin{array}{r}88,000 \\
114,000 \\
88,000 \\
5,000 \\
100,000\end{array}$ & $\begin{array}{l}170,300 \\
174,000 \\
211,200 \\
12,000 \\
240,000\end{array}$ & $\begin{array}{r}631,700 \\
114,000 \\
1,056,000 \\
60,000 \\
1,200,000\end{array}$ & $\begin{array}{r}2,451,600 \\
114,000 \\
5,297,500 \\
301,000 \\
6,020,000\end{array}$ \\
\hline Total $0 \& M \operatorname{Cos} t$ & 395,000 & 747,500 & $3,061,700$ & $14,184,200$ \\
\hline Total Annual Cost & $1,050,700$ & $1,787,800$ & $5,634,700$ & $20,797,900$ \\
\hline
\end{tabular}




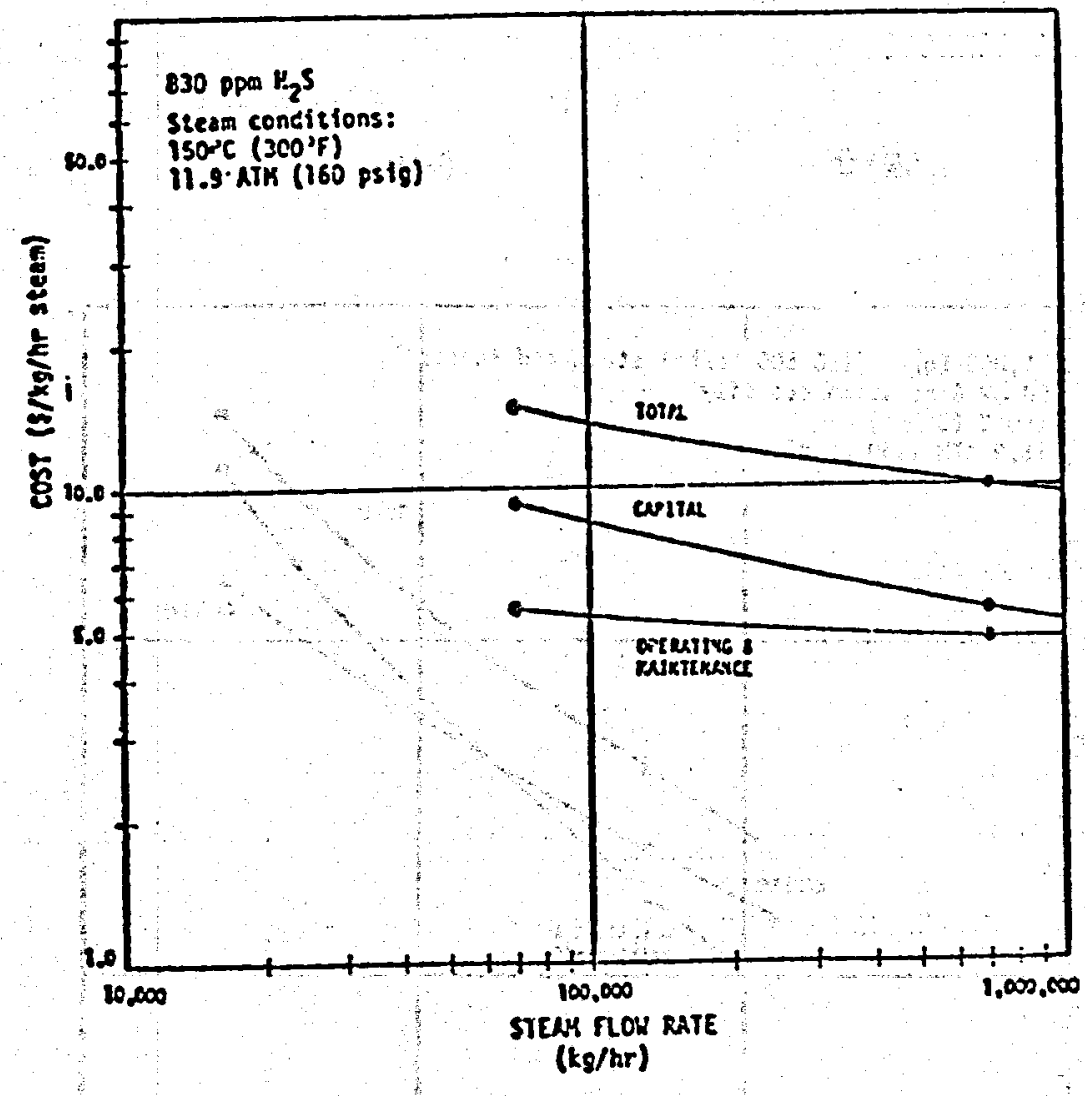

Figure 17. EIC annual cost vs. steam flow, rate

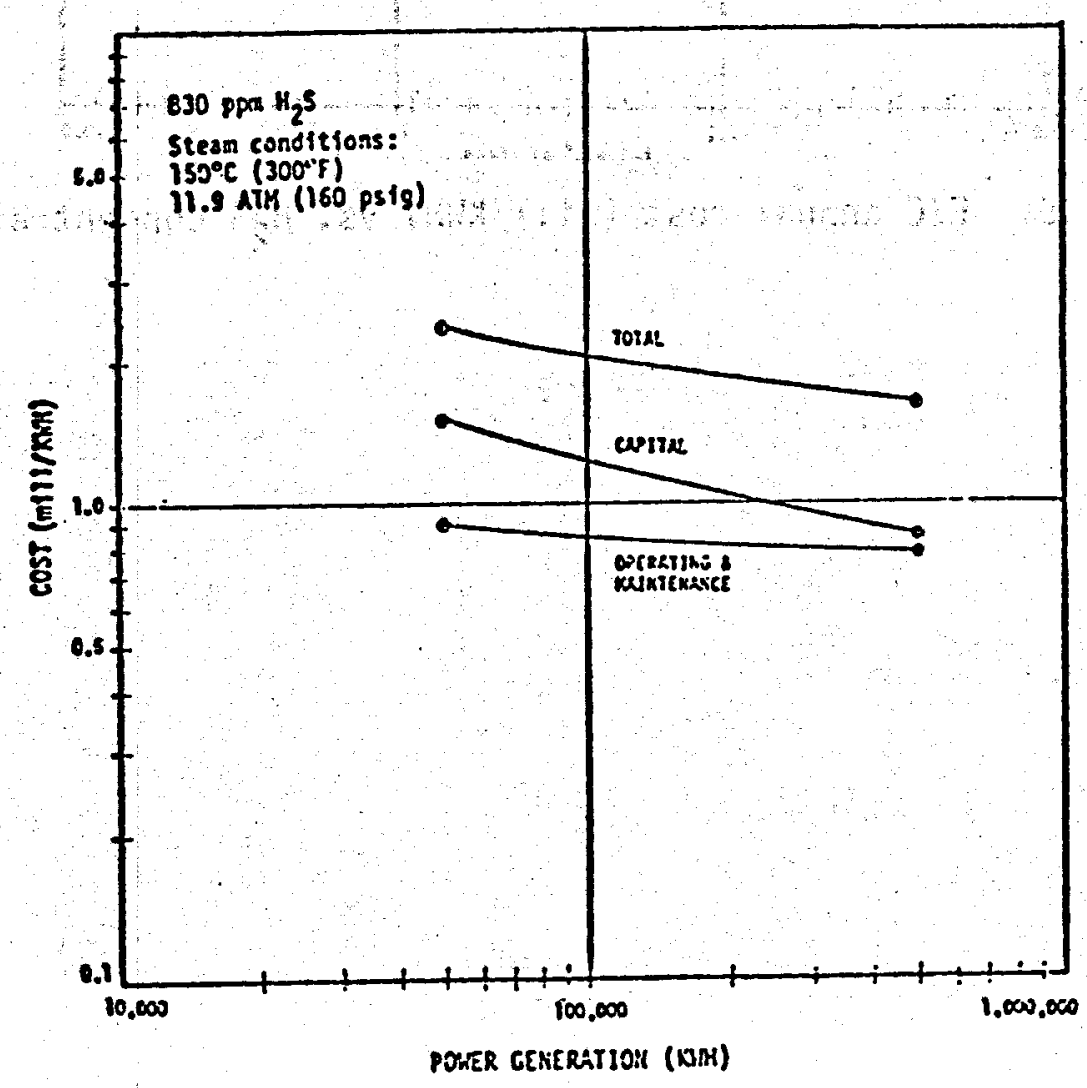

Figure 18. EIC annual cost vs, power generation 


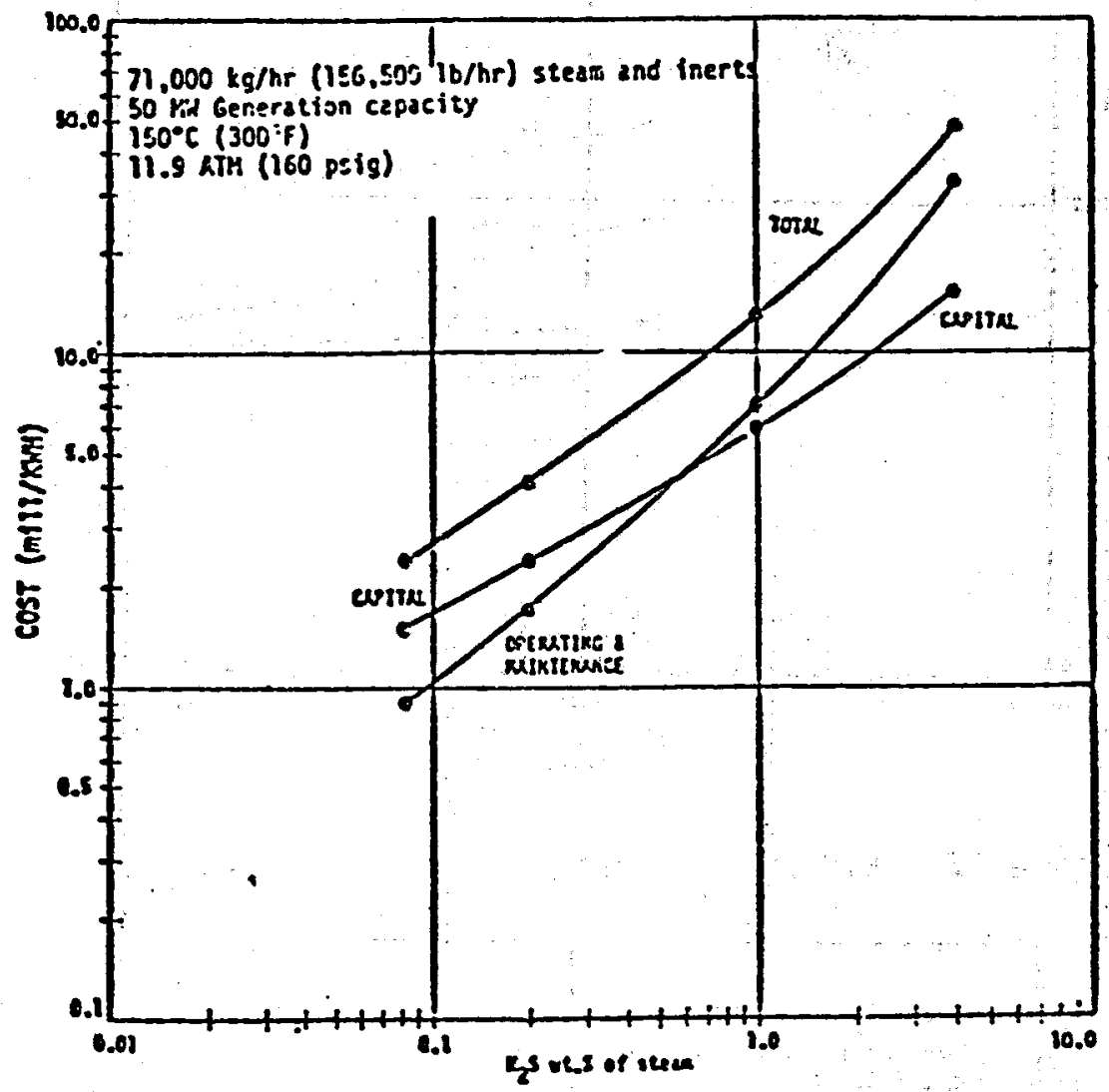

Figure 19. EIC annual cost $(\mathrm{mil} / \mathrm{KWH})$ vs. $\mathrm{H}_{2} \mathrm{~S}$ concentration 
Preliminary capital cost estimates for both the in-line and packed column systems have been developed by The Dow Chemical Company based on the results of the laboratory investigation and the following process conditions (Dow, 1977):

- Brine to be treated: 3785 liters per minute (1000 gpm)

$$
\begin{aligned}
& : 40 \mathrm{ppm} \mathrm{H}{ }^{\mathrm{S}} \\
& =177^{\circ} \mathrm{C}\left(350^{\circ} \mathrm{F}\right) \\
& : 11.2 \mathrm{~atm}(150 \text { psig) }
\end{aligned}
$$

- Brine phase : single-phase liquid

- Oxygen : hydrogen

sulfide mole ratio: $1.25: 1.0$

- Construction site : Imperial Valley, California

The preliminary installed capital cost estimates for an in-line and for a packed column system, "with the above operating conditions, are $\$ 373,600$ and $\$ 216,500$, respectively. Over 31 percent of the capital cost investment for the in-line system is required for instrumentation. Ten in-line mixer trains are required due to the $100 \mathrm{gpm}(378 \mathrm{lpm})$ mixer capacity limitation; thus necessitating a duplication of instrumentation. Capital costs would be significantly reduced if larger capacity mixers could be utilized to minimize duplication.

Capital cost for an in-line system was assumed to depend linearly on. brine flow rates. This is due to the required duplication of equipment, negating any possible savings resulting from economies of scale. Capital costs for a packed column system with differing brine flow rates can be computed utilizing the following formula:

$$
\begin{aligned}
& I A=I B\left(\frac{B A}{B B}\right)=.85 \\
& B A=\text { Brine flow rate of desired case } \\
& B B=\text { Brine fiow rate of base case }(1000 \text { gpm or } 37851 \mathrm{pm}) \\
& I=\text { Capital investment for the desired or given }(A \text { or } B) \text { case }
\end{aligned}
$$

The capital cost of a packed column system is therefore assumed to be exponentially dependent upon the brine flow rate. The exponential factor was based on that for stainless steel packed towers, 36 to 100 inches in diameter (Hesketh, 1973). The Dow prel iminary cost estimate was based on a Carpenter 20 alloy column, packed with teflon pall rings. The exponent utilized in the cost calculation applies to these materials of construction. Capital costs for the in-line and packed column systems were assumed to be independent of the hydrogen sulfide brine concentration. Operation and maintenance costs for electrical power usage and cryogenic oxygen consumption were assumed to be linearly dependent upon the hydrogen sulfide brine concentration. 
The following assumptions were utilized to estimate the annual capital and operation/maintenance costs for the in-line and packed column Dow oxygenation systems:

- Amortization period: 15 years

- Maintenance materials: 1 percent of the installed capital cost

- Maintenance labor: 10 percent down time, requiring a two-man crew, earning approximately $\$ 30$ per hour per person

- Electrical power usage: 5 horsepower oxygen compressor required for $1000 \mathrm{gpm}$ (3785 lpm) system (Galeski, 1977)

- Cryogenic oxygen usage: Calculated for an oxygen/hydrogen sulfide mole ratio of $1.25: 1.0$, an additional 20 percent required to account for system losses.

- Cryogenic oxygen cost: $\$ 0.65$ per 100 cubic feet (\$0.23 per cubic meter).

The annual cost of maintenance materials was taken as 1 percent of the installed capital cost because of the relative simplicity of equipment and design for the Dow process.

The annual costs of the in-line and packed column Dow oxygenation processes as a function of brine flow rates ranging from 15,000 to $350,000 \mathrm{l} / \mathrm{min}$, with a hydrogen sulfide concentration in the brine of $40 \mathrm{ppm}$, are given in Tables 9 and 10. Annual costs for the Dow processes for a $100,0001 / \mathrm{min}$ brine flow rate and hydrogen sulfide concentrations of $40 \mathrm{ppm}, 500 \mathrm{ppm}$ and $1000 \mathrm{ppm}$ are presented in Tables 11 and 12. Figures 22 through 27 are graphs of the normalized total., capital and operation/maintenance costs given in Tables 9 through 12. Cost estimates for the Dow oxygenation in-line and packed column systems have been developed from specific data and conditions, thus cannot be applied to geothermal resources in general.

Figures 22 and 23 give the cost, in dollars.per $1 / \mathrm{min}$, for brine flow rates from $15,000 \mathrm{l} / \mathrm{min}$ to $350,000 \mathrm{l} / \mathrm{min}$ with a hydrogen sulfide concentration of $40 \mathrm{ppm}$ for the in-line and packed column systems. Costs, in mills per KWH, for power generation capacities varying from $14.9 \mathrm{NW}$ to $347 \mathrm{MW}$ and with a 500 ppm hydrogen sulfide concentration are shown in Figures 24 and 25 . Generation capacities were computed based on a double flash energy conversion system with 8 percent overall efficiency, operating with brine conditions given previously. Figures 26 and 27 represent the costs, in mills per KWH, of the Dow processes as a function of hydrogen sulfide brine concentration at a 100,000 $1 /$ min flow rate $(98.2 \mathrm{MW})$. 
TABLE 9. DOH OXYGEMATION AYNUAL COST* FOR IN-LINE SYSTEM VS. GEOTHERMAL BRINE FLOH RATE $40 \mathrm{pPm} \mathrm{H}_{2} \mathrm{~S}$

\begin{tabular}{lcrrr}
\hline & & Brine Flow Rate $(1 / \mathrm{min})$ & \\
\hline Costs $(\$)$ & 15,000 & 100,000 & 225,000 & 350,000 \\
\hline Annual Capital & 173,100 & $1,154,600$ & $2,597,800$ & $4,041,000$ \\
Maintenance Material & 14,800 & 98,800 & 222,400 & 345,900 \\
Maintenance Labor & 50,000 & 50,000 & 50,000 & 50,000 \\
Electrical Power & 2,000 & 13,300 & 30,000 & 46,700 \\
Oxygen & 71,300 & 475,200 & $1,070,000$ & $1,664,500$ \\
Total 0 \& M Cost & 138,100 & 637,300 & $1,372,400$ & $2,107,100$ \\
Total Annual Cost & 311,200 & $1,791,900$ & $3,970,200$ & $6,148,100$ \\
& & & & \\
\hline
\end{tabular}

NOTE: * Derived from Dow Chemical Co. cost data for 1000 GPM in-line system (Dow, 1977)

TABLE 10. DOW OXYGENATION ANNUAL COST* FOR PACKED COLUMN SYSTEM VS. GEOTHERMAL BRINE FLOH RATE $40 \mathrm{pPm}_{2} \mathrm{~S}$

\begin{tabular}{lcccc}
\hline & & Brine Flow Rate $(1 / \mathrm{min})$ & \\
\hline Costs (\$) & 15,000 & 100,000 & 225,000 & 350,000 \\
& & & & \\
\hline Annual Capital & 81,500 & 409,000 & 814,900 & $1,186,400$ \\
Maintenance Material & 7,000 & 35,000 & 69,800 & 101,600 \\
Maintenance Labor & 50,000 & 50,000 & 50,000 & 50,000 \\
Electrical Power & 2,000 & 13,300 & 30,000 & 46,700 \\
Oxygen & 71,300 & 475,200 & $1,070,000$ & $1,664,500$ \\
Total 0 \& M Cost & 130,300 & 573,500 & $1,219,800$ & $1,862,800$ \\
Total Annual Cost & 211,800 & 982,500 & $2,034,700$ & $3,049,200$ \\
& & & & \\
\hline
\end{tabular}

ROTE: * Derived from Dow Chemical Co. cost data for 1000 GPM packed column system. (Dow, 1977) 
TABLE 11. DOW OXYGERATION ANRUAL COST FOR 100,000 1/MIN IN-LINE SYSTEM VS. HYDROGEN SULFIDE CONCENTRATIONI IN GEOTHERU.AL BRINE

\begin{tabular}{lrrr}
\hline \multicolumn{1}{c}{ Costs $(\$)$} & \multicolumn{1}{c}{ ppm $\mathrm{H}_{2} \mathrm{~S}$} & \multicolumn{1}{c}{1000} \\
& 40 & 500 & \\
\hline Annual Capital & $1,154,600$ & $1,154,600$ & $1,154,600$ \\
Maintenance Material & 98,800 & 98,800 & 98,800 \\
Maintenance Labor & 50,000 & 50,000 & 50,000 \\
Electrical Power & 13,300 & 166,300 & 332,500 \\
Oxygen & 475,200 & $5,940,000$ & $11,880,000$ \\
Total 0 \& M Cost & 637,300 & $6,255,100$ & $12,361,300$ \\
Total Annual Cost & $1,791,900$ & $7,409,700$ & $13,515,900$ \\
\hline
\end{tabular}

TABLE 12. DOW OXYGENATION ANNUAL COST FOR 100,000 1/mín PACKED COLUMY SYSTEM VS. HYDROGEN SULFIDE CONCENTRATION IN GEOTHERMAL BRINE

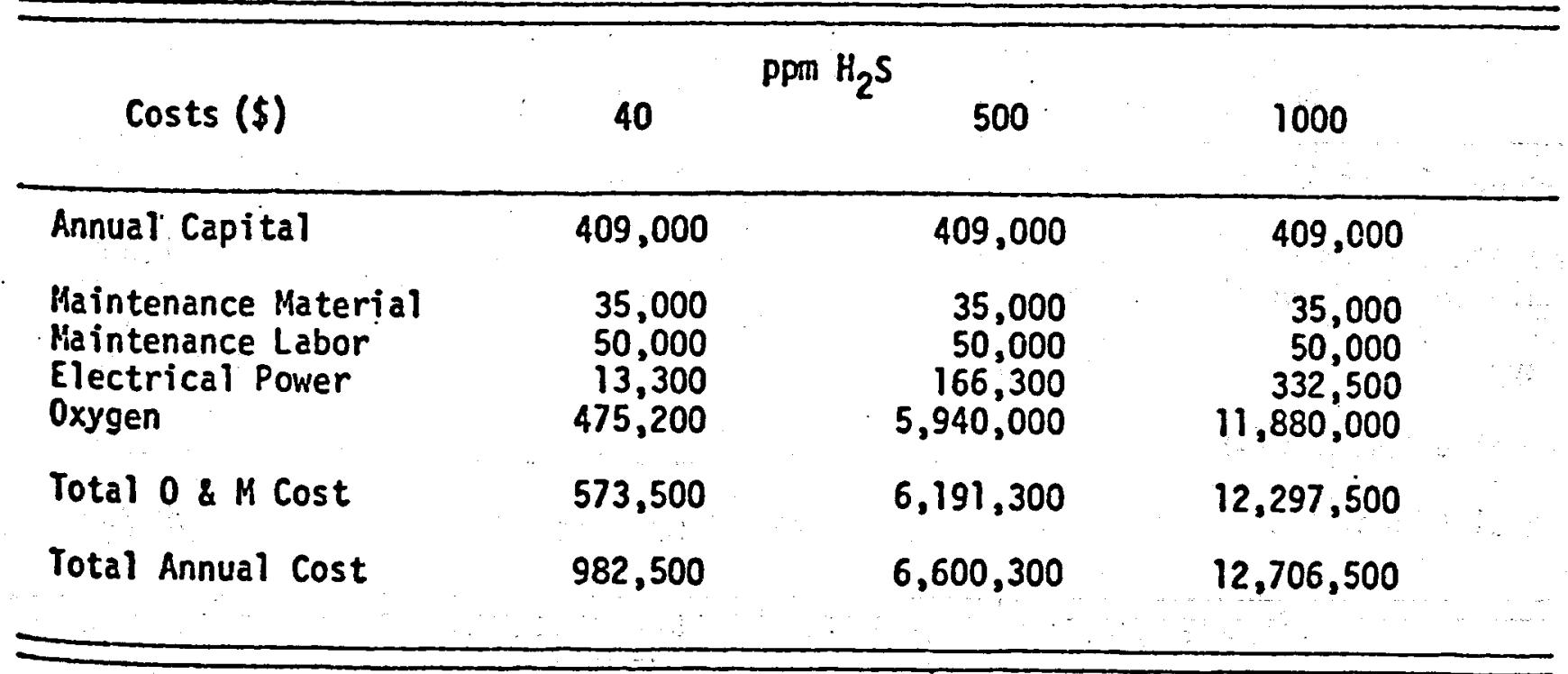




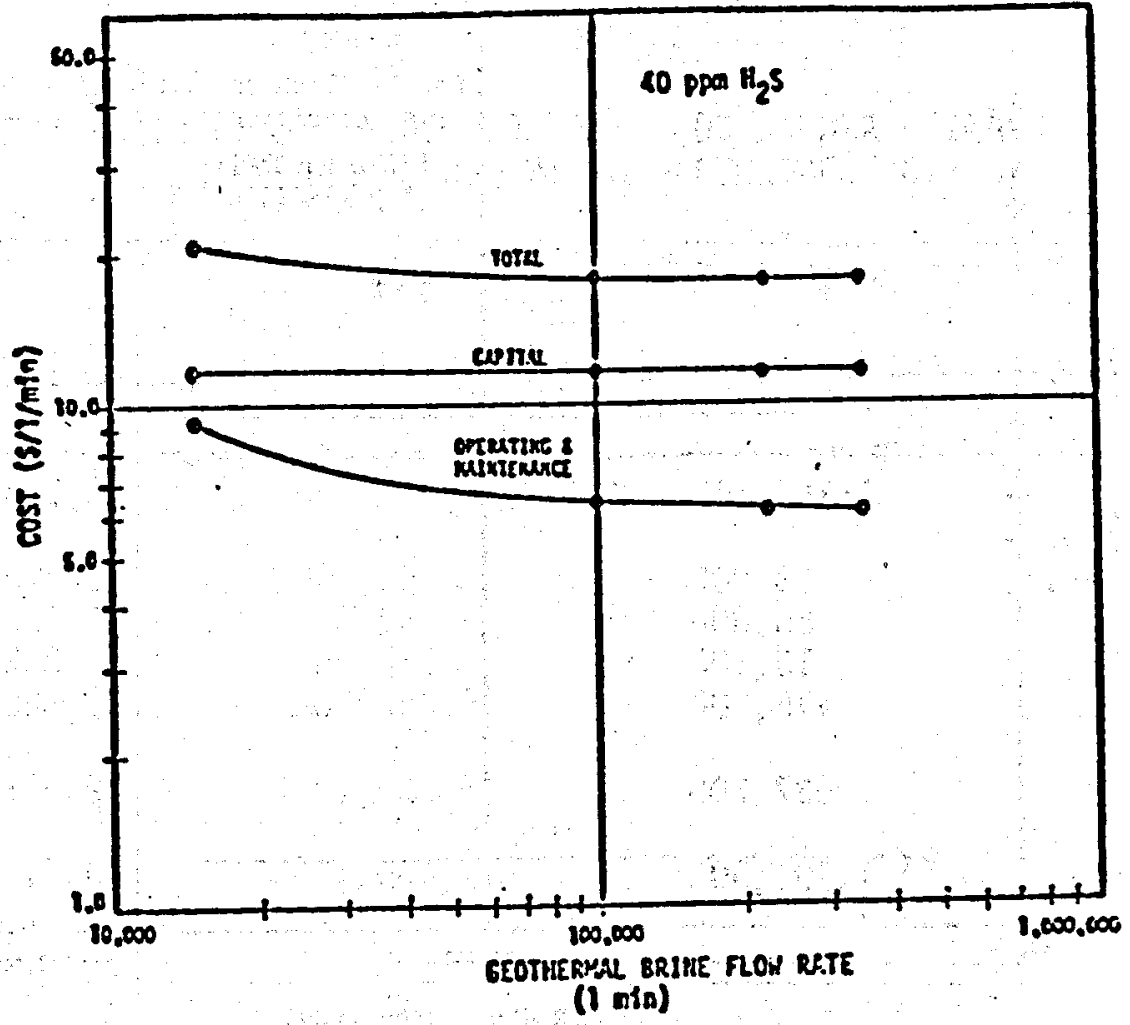

Figure 22. Dow oxygenation - in-1ine system annual cost vs. brine flow rate

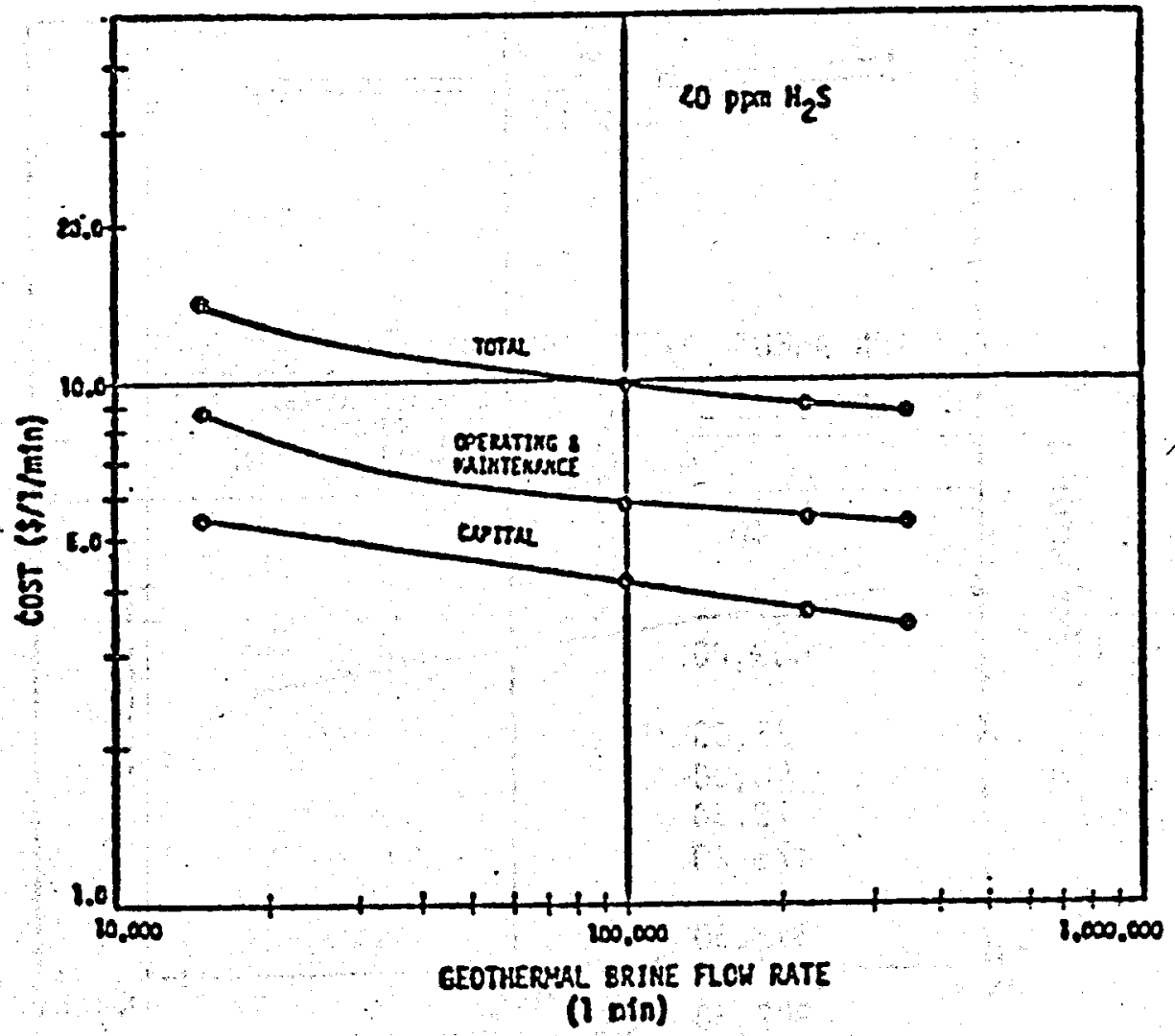

Figure 23. Dow oxygenation - packed column system annual cost vs. brine flow rate 


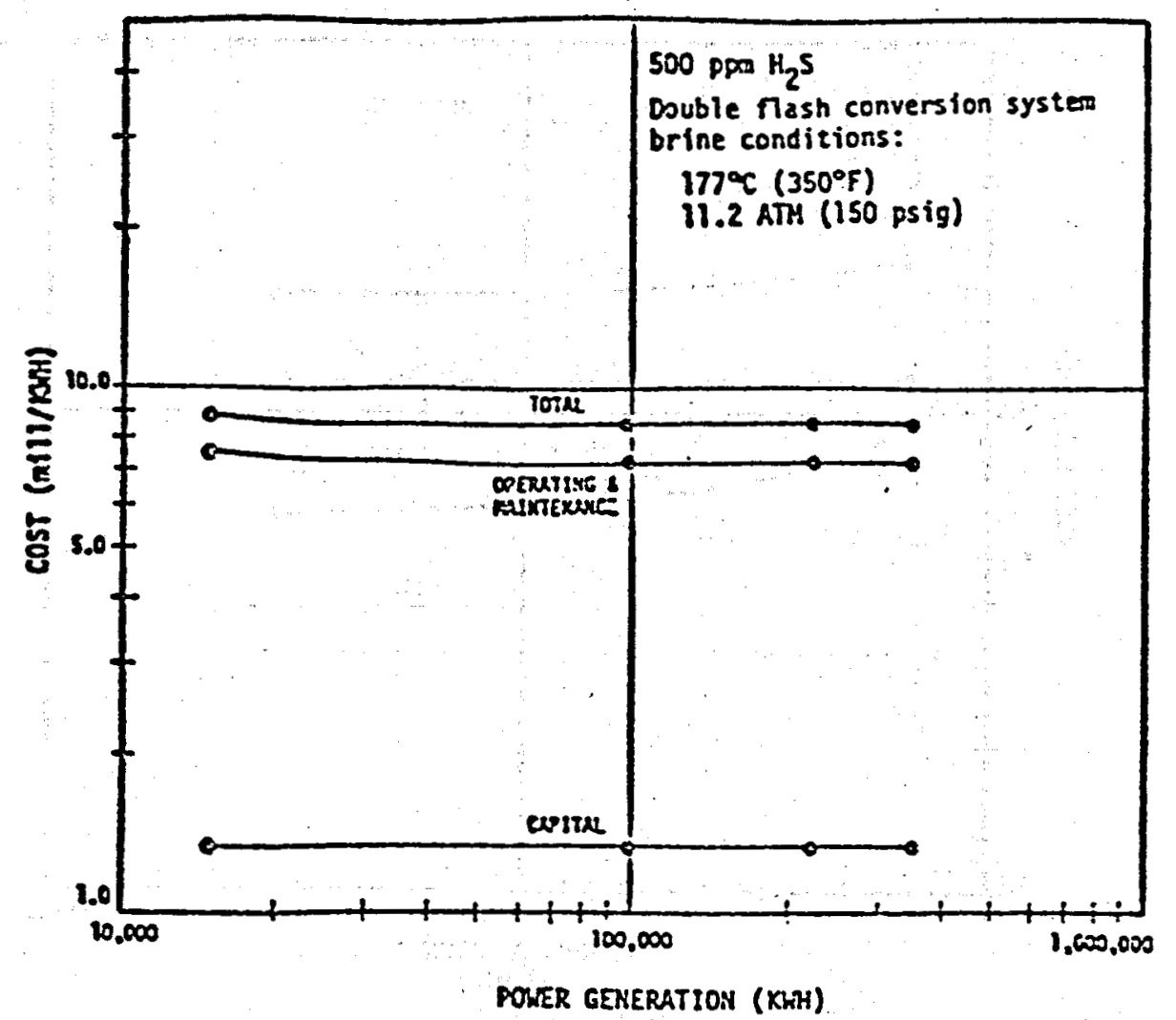

Figure 24. Dow oxygenation - in-1ine system annual cost vs. power generation

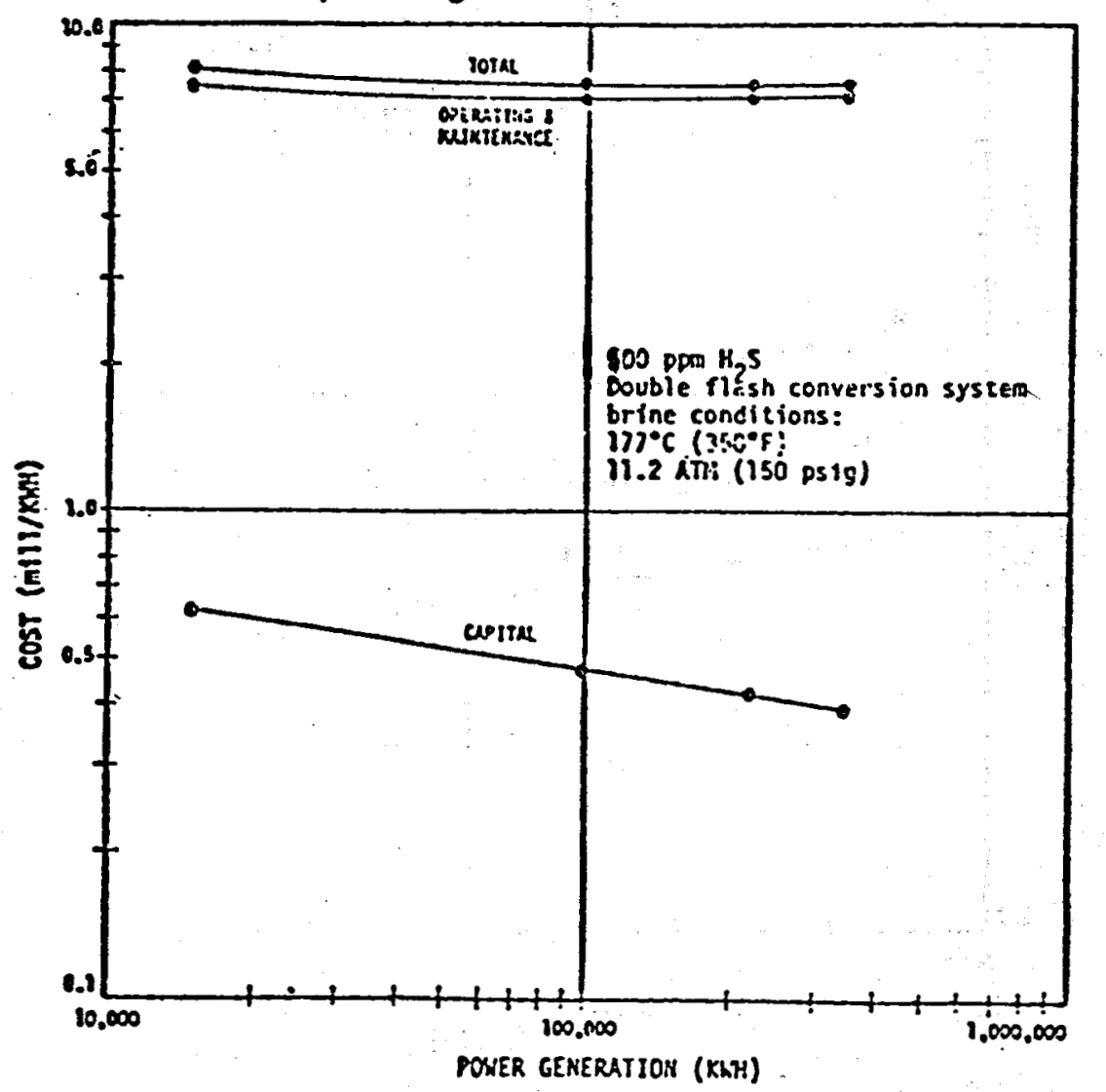

Figure 25. Dow oxygenation - packed system annual cost vs. power generation 


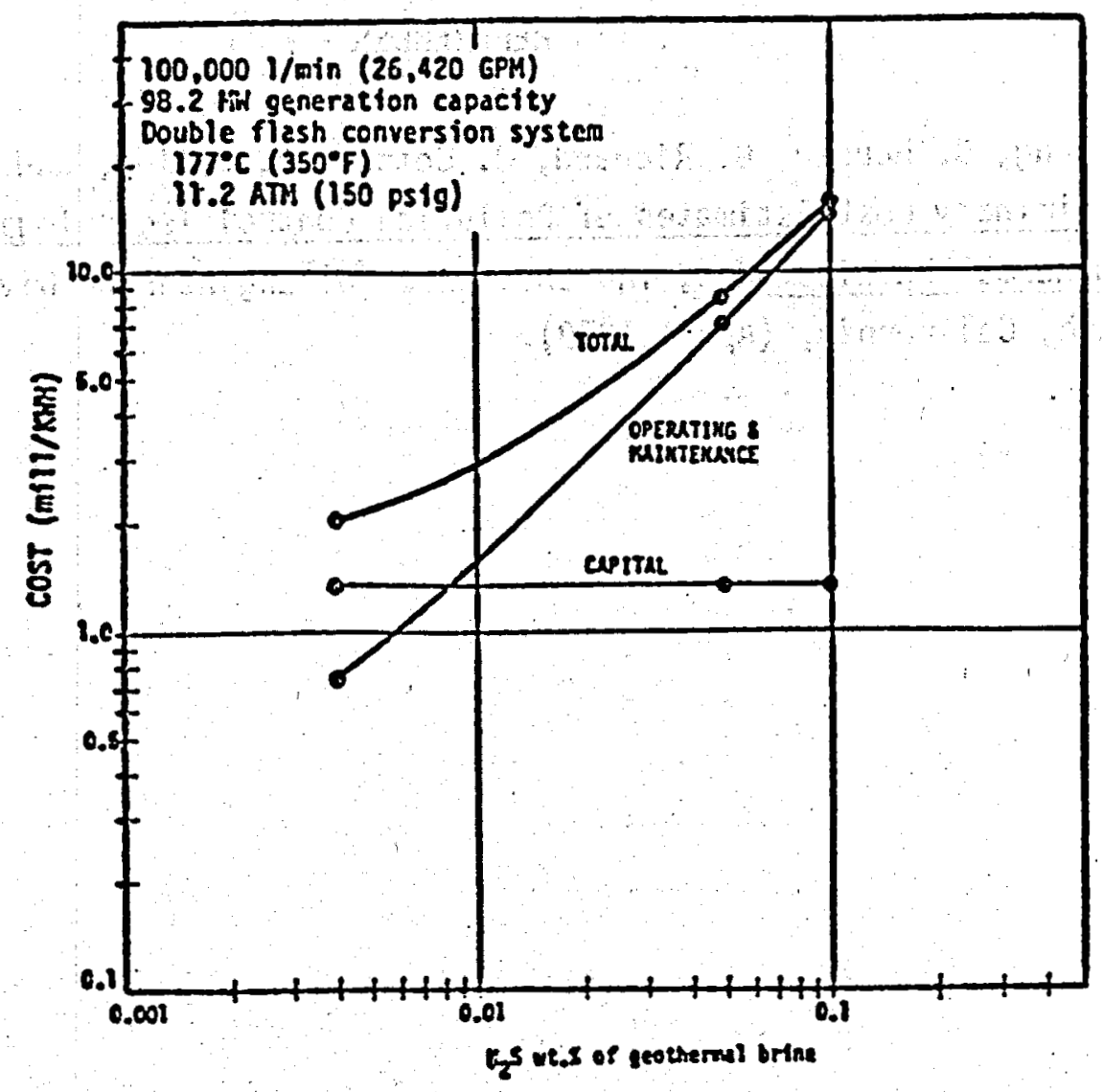

Figure 26. Dow oxygenation - in-line system annual cost vs. $\mathrm{H}_{2} \mathrm{~S}$ concentration

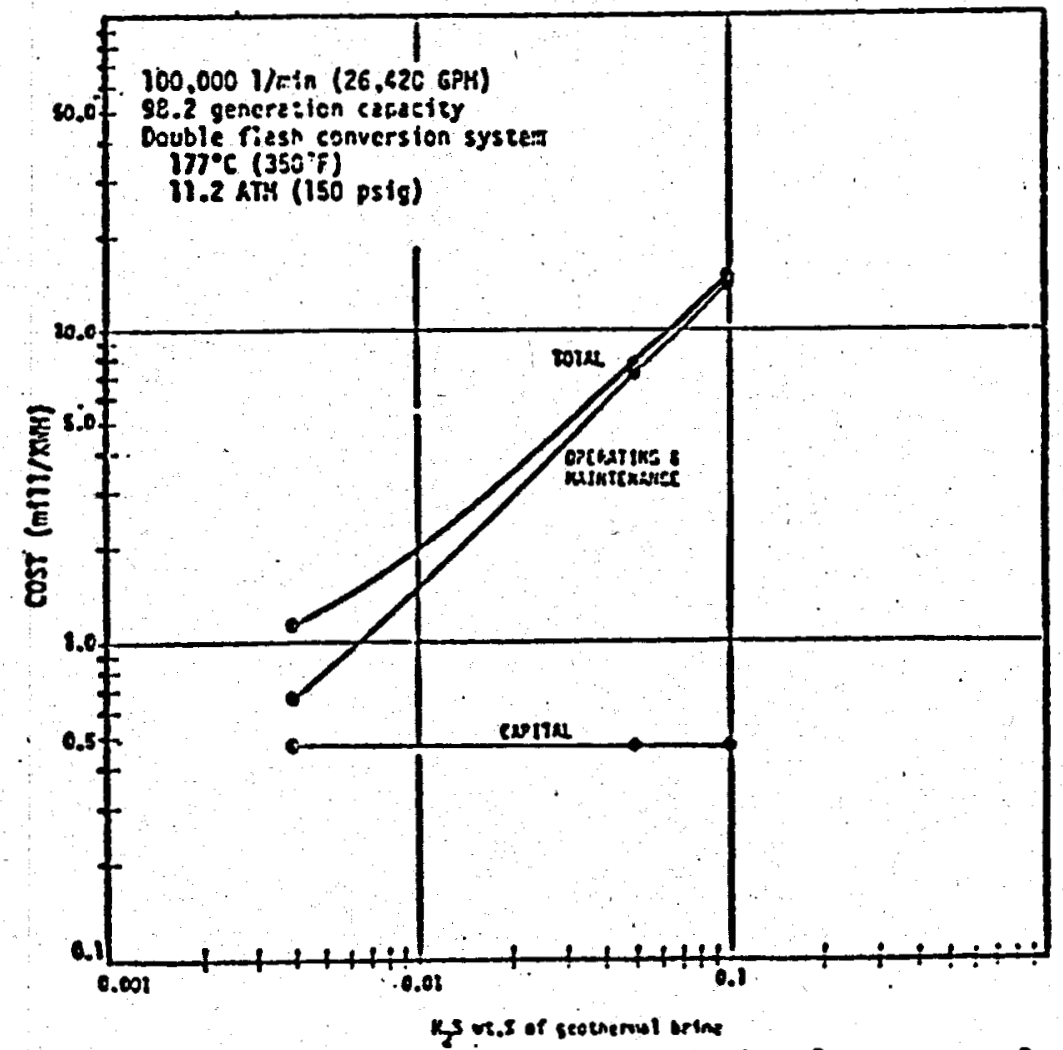

Figure 27. Dow oxygenation - packed column annual cost vs. $\mathrm{H}_{2} \mathrm{~S}$ concentration 


\section{REFERENCES}

B-1 R. Sung, G. Houser, G. Richard, J. Cotter, P. Weller, and E. Pulaski, Preliminary Cost Estimates of Pollution Control Technologies for Geothermal Developments, TRW Environmental Engineering Division, Redondo Beach, California, (April 1979). 
APPENDIX C

DEFINITION OF A CLASS I AND CLASS II-1 DISPOSAL SITE 
Class I disposal sites are those at which complete protection is provided for all time for the quality of ground and surface waters from all wastes deposited therein and against hazard to public health and wildlife resources. The following criteria must be met to qualify a site as Class I:

(a) Geological conditions are naturally capable of preventing vertical hydraulic continuity between liquids and gases emanating from the waste in the site and usable surface or groundwaters.

(b) Geological conditions are naturally capable of preventing lateral hydraulic continuity between liquids and gases emanating from wastes in the site and usable surface or groundwaters, or the disposal area has been modified to achieve such capability.

(c) Underlying geological formations which contain rock fractures of fissures of questionable permeability must be permanently sealed to provide a competent barrier to the movement of liquids or gases from the disposal site to usable waters.

(d) Inundation of disposal areas shall not occur until the site is closed in accordance with requirements of the regional board.

(e) Disposal areas shall not be subject to washout.

(f) Leachate and subsurface flow into the disposal area shall be contained within the site unless other disposition is made in accordance with requirements of the regional board.

(g) Sites shall not be located over zones of active faulting or where other forms of geological change would impair the competence of natural features or artificial barriers which prevent continuity with usable waters.

(h) Sites made suitable for use by man-made physical barriers shall not be located where improper operation or maintenance of such structures could permit the waste, leachate, or gases to contact usable ground or surface water.

(i) Sites which comply with $a, b, c, e, f, g$, and $h$ but would be subject to inundation by a tide or a flood of greater than 100-year frequency may be considered by the regional board as a limited Class I disposal site.

*From Title 23, Chapter 3, Section 2510, California Administrative Code 
Class II disposal sites are those at which protection is provided to water quality from Group 2 and Group 3 wastes. The types of physical features and the extent of protection of ground water quality divides Class II sites into the two following categories.

Class II- 1 sites are those overlying usable groundwater and geologic conditions are either naturally capable of preventing lateral and vertical hydraulic continuity between liquids and gases emanating from the waste in the site and usable surface or groundwaters, or the disposal area has been modified to achieve such capability.

Class II-2 sites are those having vertical and lateral hydraulic continuity with usable groundwater but for which geological and hydraulic features such as soil type, artificial barriers, depth to groundwater, and other factors will assure protection of the quality of usable groundwater underneath or adjacent to the site.

The following criteria must be met to qualify a site as Class II:

(a) Disposal areas shall be protected by natural or artificial features so as to assure protection from any washout and from inundation which could occur as a result of tides or floods having a predicted frequency of once in 100 years.

(b) Surface drainage from tributary areas shall not contact Group 2 wastes in the site during disposal operations and for the active life of the site.

(c) Gases and leachate emanating from waste in the site shall not unreasonably affect groundwater during the active life of the site.

(d) Subsurface flow into the site and the depth at which water soluble materials are placed shall be controlled during construction and operation of the site to minimize leachate production and assure that the Group 2 waste material will be above the highest anticipated elevation of the capillary fringe of the groundwater. Discharge from the site shall be subject to waste discharge requirements.

From Title 23, Chapter 3, Section 2511, California Administrative Code 
APPENDIX D

PROPOSED STATE OF CALIFORNIA REGULATIONS

FOR $\mathrm{H}_{2} \mathrm{~S}$ ABATEMENT AT THE GEYSERS 
Proposed California regulations concerning $\mathrm{H}_{2} \mathrm{~S}$ control at The Geysers are presented in the following.

(1) A July 1978 memorandum from the California Air Resources Board (ARB) regarding the status of The Geysers geothermal $\mathrm{H}_{2} \mathrm{~S}$ control strategy.

(2) A July 1978 paper, "Air Quality as the Limiting Factor on

Development of the Geysers Geothermal Resources," presented at the Geothermal Resources Council Annual Meeting, Hilo, Hawaii, July 1978. The paper has been reproduced from Transactions, Vor. 2 (1978) pp. 345-349, with permission from the Geothermal Resources Council. 
fíc

To Hilliam H. Lewis, Jr.

Dete : July 19, 1978

Executive Officer

Subject Status of Geysers

Geothermal $\mathrm{H}_{2} \mathrm{~S}$

Control Strategy

Neil A. Hoyer, Technical Assistant

to Executive Office

From \& Air Resources Bcard

At the April 26, 1978 Board meeting, the Boaro accepted the staff's control strategy and the requirements it encompassed. The Board directed the staff to consicer some appropriate modifications in the steam supily requirements to reflect some additional industry concerns. * Also, the APCOs and APCD Board representatives from Lake County and NSAPCD were to meet with the Executive officer and ARB staff to accelerate the process of both APCD's adopting and enforcing the same requirements for geothermal electric power development in the two counties.

Frior to the $4 / 26 / 78$ meeting, the NSAPCD had since DEceniber 1977 been attempting to improve its geothermal regulations and adopt new ones. During this period and subsequently, the ARB staff has discussad and met with the NSAPCD on implementirg the control strategy. On June 27, 1978, the. NSAPCO Board adopted new geothermal requirements.

The staff is unaware of any effort ty the Lake County APCD up to this time to adopt the elements of the control strategy.

\section{Discussion of Control Strategy Concept}

1. The control strategy is meant to apply equally in both counties throughout the Geysers KGRA. The probability of developing an aiternative strategy based on extensive airshed simulation modeling seems small. The data collection efforts will be extraordinarily costiy and time consuming and vould further impede (unnecessarily) geotherma] developinent.

2. Based on current information, the minimum required emission limits are feasible and necessary to generally obate $\mathrm{H}_{2} \mathrm{~S}$ and achieve and maintain the standard where it is now being violated and causing a problem.

3. Irherent with the adoption and enforccinent of the contrei stratcgy are three criteria by which neil geothermal prcjects should be compared:

a. Will the projoct meet the requisite emission linits?

*Northern Sonoma Air Pollution Control District 
b. Hill the project's emissions cause a violation of the $\mathrm{H}_{2} \mathrm{~S}$ standard? (Due to location, topography, metecrology, source size, proximity of receptors, etc. A naw project may need to emit less than the minimum emission limits in order to not violate the $\mathrm{H}_{2} \mathrm{~S}$ standard. However, if due to these same conditions a nely project could emit more without a violation, the limits should not be relaxed since the emission limits are necessary to mitigate an areavide problem caused by many contributing sources.

c. If the new project's applicant is already operating sources at the Geysers, are those sources in compliance with the requisite emission limits?

Implementation of the control strategy requires that new geothermal operators (i.e., DWR, NCPA, Dow) meet criteria A and B while existing operators meet all three criteria before a new project can be approved.

With these three criteria, the current NSR process is not necessary. Approval of new sources need not be tied to the performance of existing sources through "trade offs". As Tong as the three criteria are met and the control strategy and its emission limits are correct, "trade offs" are not nacessary.

4. Presently, both APCDs require the steam production wells and the power plant to be permitted separately. This is unnecessary and unreasonably divides the project in two parts which cannot exist without each other. Also, this dual permitting further contributes to the current resolution of responsibility for $\mathrm{H}_{2} \mathrm{~S}$ released during steam "stacking" caused by a power plant cutage or shutdown. PGRE currently accepts no responsibility and the steam supplier (Union $0 i 1$, now) is limited in options to fully abate this $\mathrm{H}_{2} \mathrm{~S}$ source. Complemientary power plant design (i.e., dual power plant units as with Units 3 and 4,5 and 6,7 and 8 , 9 and 10 as opposed to single units like Units $11,12,13$, $14 ; .15$, etc.) with well throttling to $50-65 \%$ of full steam flow and extensive steam transmission pipeline interconnections car minimize to a great extent the need to chemically abate $\mathrm{H}_{2} \mathrm{~S}$ during power plant outages. However, due to the artificial division of responsibilities between the steam supplier and user, optimum total system design is generally not being considered for future electric powar development. By combining the permits, the APCO can bring the two parties together and joint responsibility can be established for $\mathrm{H}_{2} \mathrm{~S}$ released during steam "stacking". 
The following is a staff comparison of the racentily adoptad (6/27/78) NSAPCD geothermal requirements:

Comparison of ASAPCD and ARB Requirements for Geothermal Power Plants

Effective Date

Jen 1,1979

Jàn 1, 1979 None

Jan 1, 1980 New units in operation after this date enit no fiore than $100 \mathrm{~g} / \mathrm{hr} /$ Ginll!; for Units $1,2,7,8,9$ and 10 . the A.PCO will determine based on need requireinents effective $1 / 1 / 82$ and $1 / 1 / 85$

Jan 1,1982 For Units $3-6,11$ and 12 , each emit no more than 200 $\mathrm{g} / \mathrm{hr} / \mathrm{GMH}$.

Len 1, 1984

Jen 1, 1985

Net: units operating after

this date einit no more than

$50 \mathrm{~g} / \mathrm{hr} / \mathrm{Glth}$ (not imp)-

mented until APCO hearing

1 year in advance-1/1/84)

Jan 1, 1906

Nevi units constructed after this date emit no more thin $50 \mathrm{gm} / \mathrm{hillit}$ of $\mathrm{H}_{2} \mathrm{~S}$ 
Effective Date

Jan 1, 1990

$\operatorname{Jan} 1,2000$
NSAPCD

Units with surface condensers operating prior to $1 / 1 / 80$ emit no more than $50 \mathrm{~g} / \mathrm{hr} / \mathrm{GHW}$ (not implemented until APCO hearing I year in advance-1/1/89):

Units with direct contact: condensers operating prior to $1 / 1 / 80$ (Units 1-12) emit no more than $100 \mathrm{~g} / \mathrm{hr} / \mathrm{GMM}$ (not implemented unti) APCO hearing 1 year in advance-1/1/99).
ARB

Ail units cons tructed after $1 / 1 / 79$ (except Unit 12) emit no more than $50 \mathrm{gm} / \mathrm{Hith}$.

Units $1-12$ emit no more than $100 \mathrm{gm} / \mathrm{Mith}$.

\section{Comments on Power Plant Requirements}

1. Staff is apprehensive about the NSAPCD $1 / 1 / 79$ requirement for Units $3,4,5,6,11$ and 12 since it may not cause the power plant operator to seriousiy consider permanent, effective $\mathrm{H}_{2} \mathrm{~S}$ contrcls for these units. The allowance for quarterly changes in allocating emission reductions. betiveen units inject considerable uncertainty in determining the actual power plant performance levels.

The following tables indicate the emissions and control requirements impacts:

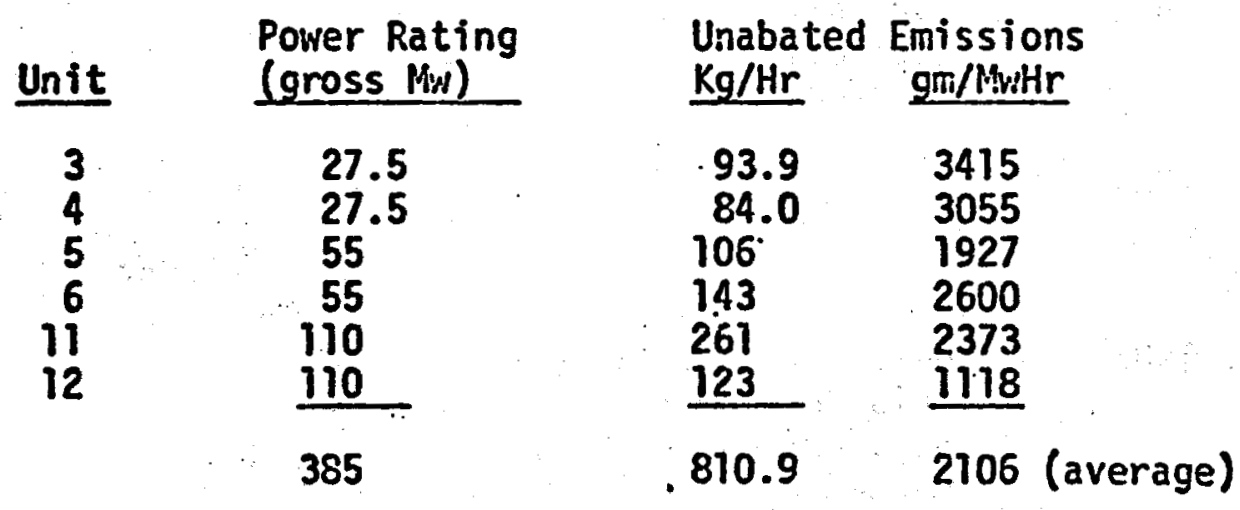


NSAPCD Requirements

$90 \%$ reduction or $200 \mathrm{~g} / \mathrm{hr} / \mathrm{GHW}$ Emissions

Unit $\mathrm{Kg} / \mathrm{hr}$

\begin{tabular}{rr}
3 & 9.39 \\
4 & 8.4 \\
5 & 10.6 \\
6 & 14.3 \\
11 & 26.1 \\
12 & 12.3 \\
\hline
\end{tabular}

81.09

(210.6 gm/ $\mathrm{Mm} \mathrm{Hr}$ average and $729.81 \mathrm{~kg} / \mathrm{hr}$ reduction) (average)
ARB Requirements

Each to $200 \mathrm{gm} / \mathrm{im}$ ithr Enissions $\mathrm{Kg} / \mathrm{hr} \quad$ Reduction

5.5

5.5

11.0

11.0

22.0

22.0

77.0

(733.9 $\mathrm{kg} / \mathrm{hr}$ reduction)

The power plant operator (PG\&E) has consistently indicated it does not know if any of these requirements can be met on time. Recent field studies using hydrogen peroxide and sodiun hydrcxide have shown considerable improvement in the dissolving of $\mathrm{H}_{2} \mathrm{~S}$ and removal in the concensate return ine on power plants equipped with the Ferrifloc ("iron catalyst") process. If PGaE moves rapidij, these six units could be equipped for $\mathrm{H}_{2} \mathrm{O}_{2} / \mathrm{NaCH}$ treatment by $1 / i / 79$. Othervise, PGaE vill violate the emissions requirerent and variance or abstement order actions will be necessary.

If an abatement order is enforced, up to 385 th of geothermal electric capacity could be lost, but only temporarily until the emissions requireinent is met. PG\&E contends the replacenent power would come irom fossil fuel-fired poiver plants causing increased emissions. During the winter, air quality in Northern California may not be adversely inpacted by the incremental increase, and in the spring additional hydropower reserves (including Pacific ilorthyest intertie) are generally availat?e. This was the case this spring and the Geysers units were substantially curtailed at nighit.

If a variance is enforsed, staff believes the best approach would be to require supplemental $\mathrm{H}_{2} \mathrm{O}_{2}$ / $\mathrm{MaOH}$ treatrient at Units 1 , $2,7,2,9$ and 10 to the extent thot ine total $\mathrm{H}_{2} \mathrm{~S}$ reductions from all units operating is at las $733.9 \mathrm{~kg} / \mathrm{hr}$. Teimporary addition of the Serrisloc process to these currentiy uncontrolled units should not be required unless PGSE denioristrates the $\mathrm{H}_{2} S$ removal effectiveness, costs ond operational efficiencies are superior to $\mathrm{H}_{2} \mathrm{O}_{2} / \mathrm{MiaOH}$ treatrient alone. 
2. The ARB requirement for new power plants on January 1, 1979 may be redundant if the construction schedules for new Units 13, 14 and 15 (equipped with surface condensers and Stretford units) continue to slip. However, NSAPCD has no requirements for new units. until January 1,1980 and at least one of the new units could be finished and not have to control its $\mathrm{H}_{2} \mathrm{~S}$ until January 1, 1980.

3. NSAPCD has yet to establish control requirements for the existing uncontrolled Units $1,2,7,8,9$ and 10. Staff believes it has demonstrated the need to control these units as an integral part of the control strategy $(4 / 26 / 78)$. The $1 / 1 / 84$ effective date of the control requirement reflects a time schedule with sufficient allowance for denionstration of new control technologies (upstream abatement - EIC or Coury processes), further development and application of existing technologies (Ferrifloc with suppleniental $\mathrm{H}_{2} \mathrm{O}_{2} / \mathrm{NaOH}$ treatment), and the possible retrofit with surface condensers/Stretford and supplenental $\mathrm{H}_{2} \mathrm{O}_{2} / \mathrm{NaOH}$, if needed.

Unless existing units are controlled permanently, there will not be adequate allowance for new units and their controlled emissions.

4. NSAPCO has not fully adopted the most stringent future requirenients $(1 / 1 / 8550 \mathrm{gm} / \mathrm{im} \mathrm{hH}$ for new units, $1 / 1 / 9050 \mathrm{gm} / \mathrm{MH} / \mathrm{Hr}$ for existing Stretford units, and $1 / 1 / 2000105 \mathrm{gm} /$ Muritr for Units 1-12) pending future determinations by the APCO. The staff believes it has demonstrated the need and to the extent possible at this time the feasibility of these limits in the $4 / 26 / 78$ report to the Board. As such, these requirenents serve as minimum design obje:tives for future developments and should focus the necessary research and development efforts. The inherent ambiguity of the NSAPCD approach will lessen this facus. Also, the APCO already has the authority and responsibility to reexamine future control requireinents. Until there is unaini iguous evidence that the current $\mathrm{H}_{2} \mathrm{~S}$ problen:s are being mitigated and future developments are proceeding without exacerbating $\mathrm{H}_{2} \mathrm{~S}$ a ir quality levels, these future limits appear necessary. 
Comparison of NSAPCD and ARB Steam "Stacking" Requirerents

\section{NSAPCD}

June 1, 1979 - existirg steam trans!nission systeins (pernitted as of $6 / 1 / 78$ )

"scheduled" outage - if expected 4 houirs or less, no abaterrent if expected more than 4 houirs, reduce $\mathrm{H}_{2} \mathrm{~S}$ released within 1 hour by $90:$ : of $\mathrm{H}_{2} \mathrm{~S}$ in the total stearn flow for dual uinit posier plants and by $50 \%$ of total siean floin for single unit power plant or when both units of a dua? power plant have a siaultenzous outage or reduce $\mathrm{H}_{2} \mathrm{~S}$ emissions to not more than $15 \mathrm{~kg} / \mathrm{hr}$.

"Unscheduled" outage - same limits as above except accomplish within 4 hours or less

-- neif systems

"urischeduled" outage - within 4 hours or less, reduce $\mathrm{H}_{2} \mathrm{~S}$ released by $90 \%$ of the $\mathrm{H}_{2} \mathrm{~S}$ in the total steam fio: for dual units, by $65 \%$ for single units or for simul tansous outage of both units at a dual plant or reduce $\mathrm{H}_{2} \mathrm{~S}$ emissions to not more than $15 \mathrm{~kg} / \mathrm{hr}$.

"scheduled" outage -

same linits as above except accomp? ish with in 1 hour.

$\underline{A P B}$

Jan. 1, 1980 - reduced $\mathrm{H}_{2} \mathrm{~S}$ from "stacked" steam to no rivire tinan $35 \%$ of the $\mathrm{H}_{2} \mathrm{~S}$ at full steam flow within 15 minutes of the outags

ASAPCD

Jan. 1, 1980 - determine necd for more stringent requirenents for existing (pre 6/1j78) systems

Jan. 1, 1982 - new systems

"unscheduled" outage - same liinits as 6/1/79 excopt. $\mathrm{kg} / \mathrm{hr}$ limit to be determined uy $6 / 1 / 81$

"scheduled" outage -

same as above, except acconiplished within 1 hour, and :o abatement of 4 hour or less outage. 
Hiilian H. Lewis, Jr.

$\underline{A . P 3}$

Jan. 1, 1986 - reduce $\mathrm{H}_{2} \mathrm{~S}$ from "stucked" steam to no more than $10 \%$ of the $\mathrm{H}_{2} \mathrm{~S}$ at full stean floi witnin 15 minutes of the outage.

\section{COMME!ITS}

1. Through separate discussions with industry representatives and the NSAPCD, the staif has received information indicating one hour response time on outages is both reasonable and feasible. However, there appears to be no substantial reason for distiriguishing between "schesuled" and "unscheduled" outages. The star" bei ieves the NSAPCE requirements silould be changed to reflect tie intent of the Control Strategy tinat tile fiold-uide emissions be substantially the sarre whether tinere is an outage or not. The nodel requireirents would be:

Jan. 1, $1980-$

A. At dual unit power plants for outages of 4 or more hours, tine combined $\mathrm{H}_{2} \mathrm{~S}$ enissions of the operating unit and the $\mathrm{H}_{2} \mathrm{~S}$ from the "stacked" steam snall not exceed $110 \%$ of the maximum allo:iable $\mathrm{H}_{2} \mathrm{~S}$ emissions from both units allowed during normal operation and this is to be reached within i hour of the start of the outage.

B. At dual unit power plants lith simultaneous outage of both units expected to last 4 or more hours, the $\mathrm{H}_{2} \mathrm{~S}$ emissions shall be rediced within 1 hour of the start of the cutage to no more than $50 \%$ of the $\mathrm{H}_{2} \mathrm{~S}$ present with full steam floil to both units.

C. At single unit po:ver plants for outages of 4 or more hours, the $\mathrm{H}_{2} \mathrm{~S}$ emissions shall be reduced within 1 hour of the start of the outage to no more than $50 \%$ of the $\mathrm{H}_{2} \mathrm{~S}$ present with full steam fiou.

Jan. 1, 1981 - All ney units constructed after this date, for outage of 4 or more hours, $\mathrm{H}_{2} \mathrm{~S}$ emissions released during steam "stacking" shall not exceed $110 \%$ of the maximum allowable po:ver plant $\mathrm{H}_{2} \mathrm{~S}$ emissions al lowed during normal operation and this is to be achieved within 1 hour of the start of the outage. 


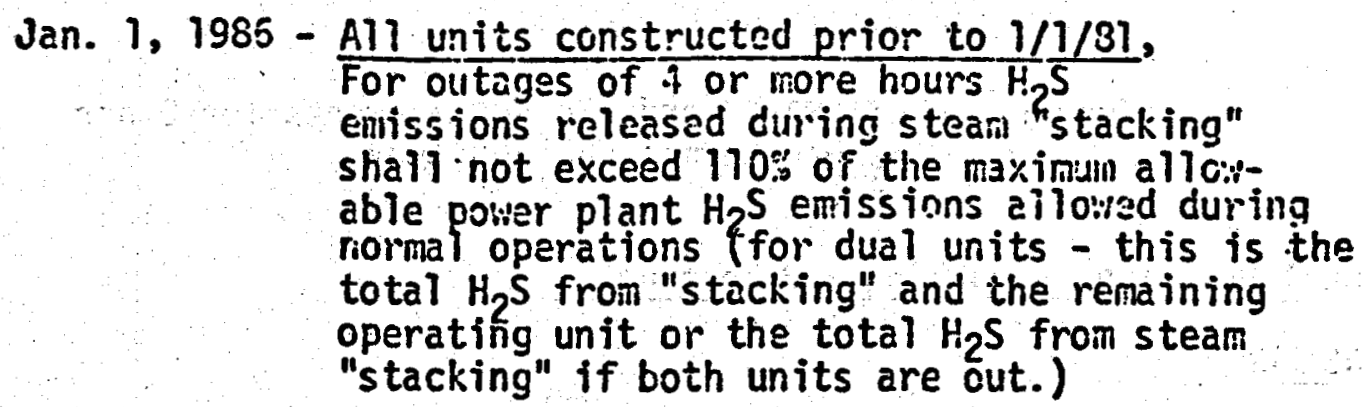

From now to January 1986, existing steam transmission sys tem need to be upgraded through interties so poiler piant outages at existing units do not need to cause unnecessary stean releases. As nay power plants are proposed, siting vill be an important consideration if interties with existing units (like Urits 13,14 , and 15) are to be made. Design of ney power plants as dual units can lessen the need to intertie with other power plants to abate $\mathrm{H}_{2} \mathrm{~S}$ releases caused by power plant outages. 
Comparison of HSAPCD and ARB Requirenents for Other Geothermal $\mathrm{H}_{2} \mathrm{~S}$ Sources

Hell Drilling, Reworking and Testing

NSSSPCD

June 1, $1979-\mathrm{H}_{2} \mathrm{~S}$ limited to $5 \mathrm{~kg} / \mathrm{hr} /$ viell unless a less restrictive limit is approved by the APCO.

Jan. $1,1980-\mathrm{H}_{2} \mathrm{~S}$ limited to $2.5 \mathrm{~kg} / \mathrm{hr} / \mathrm{well}$ unless i less restrictive limit is approved by the APCO.

APB

Jen. 1, $1980-\mathrm{H}_{2} \mathrm{~S}$ limited to $2.5 \mathrm{~kg} / \mathrm{hr} / \mathrm{kell}$ under any conditions.

Comients: The technology $\left(\mathrm{H}_{2} \mathrm{O}_{2} / \mathrm{MaOH}\right.$ ) for effectiveiy abating $\mathrm{H}_{2} \mathrm{~S}$ emissions from viell drilling has been demonstrated as practical and feasibie. As the gecthermal resource is developed, well drilling testing, rewcrking, etc., will ircrease as the number of production tvells increases and the $n \in \equiv d$ for maliz-up wells and walls for ney projects increases. In order to moderate the jevelopment of an areavide $\mathrm{H}_{2} \mathrm{~S}$ source from vieli drilling activities, a limit of $2.5 \mathrm{~kg} / \mathrm{hr} / \mathrm{well}$ is needed. Regulation of this activity on a case-by-case tasis will become unnecessarily burdensome to these tyo small APCDs.

Small Sources (:iell and pipeline bleeds, valves, meters)

NSAPCD

Jen. $1,1980-2.0 \mathrm{~kg} / \mathrm{hr}$ per source unless a less restrictive limit is approved by the APCO.

Jan. $1,1982 .-1.0 \mathrm{~kg} / \mathrm{hr}$. per source unless a less restrictive limit is approved by the APCO.

Jen. 1, $1985-0.5 \mathrm{~kg} / \mathrm{hr}$ per source unless a less restrictive limit is approved by the APCO.

AR3

Jan. 1, 1980 - (Including vell drilling, reworking, testing) $5 \mathrm{~kg}$ per 1000 Mal of electric poiser ( $5 \mathrm{gm} / \mathrm{Mw}$ ith $)$. 
Cominents: The staff believes the separation of well activitics from ctlier sources is an excel lent idea. The ASAPCD Tinits seeil reasonably achia:able. The HSAPCD limits for other sources also seen feasible. In the long ter.... pipaline vents may be el iminated and steam managemant practices ran arjust to this occurrence. However, no regulation seens warranted at this tiria.

Therna? 4 ("Iild H!ell")

NSAPCD (no requirements)

ARB

Jan. $1,1982-\mathrm{H}_{2} \mathrm{~S}$ shall not exceed $1.5 \mathrm{~kg} / \mathrm{hr}$.

Comments: This source of unabated $\mathrm{H}_{2} \mathrm{~S}$ has existed since the early $1960 \mathrm{~s}$ due to a well blowout. Thernal power (well o:kner) is slowly proceeding with a pian to generate some power and cause some $\mathrm{H}_{2} \mathrm{~S}$ abatement at this. source. Progress has been excruciatingly sicul and favcrable results ney not occur. Unless favorable action occurs soon, the HSÁPCD well driliing limits should be applied to this source or the Division of 0 il and Gas should be petitioned to cause the well oviner to permarently shut in this well as part of its abandonment.

cc: Harjoris Evans

A7 Gorúson

Ton Alisitin

Ro:l Ku:ullia

Rej Tuvell! 
Geothemal Resources Council, TRAISACTIOHS, Vol. 2 July 1978

AIR QUALIT AS THE LIMITIMG FACTOR ON DEVELOPMENT OF THE GEYSERS GEOTHERMAL RESOURCES

Iarry Joyce and Roger A. Fontes

Staff Members of the Supply Assessment of fice GALIFORNIA ENERGY COMMISSION

\begin{abstract}
An air quality problem exists at the Geyser: California is a result of hydrogen sulfide (B,5) emissions from geothermal power genertion. In this report the policy and legal issues engulfing the air quality problem and efforts to witigate the problem are examined. Estimates are made of the air quality impacts of future generation capacity based on utility electricity supply plans as submitted to California Energy Comission (CEC). The status of current and developing $H_{2} \mathrm{~s}$ abrement technologies is examined for avilability and technical characteristics. A.rlysis is provided on the prospect and consequences of inadequate control of $\mathrm{H}_{\mathrm{S}} \mathrm{S}$ emiscions. $\mathrm{H}_{2} \mathrm{~s}$ control efficiencies of $1 \mathrm{e}^{2} \mathrm{~s}$ than 95 percent may ultimately be ineffective if full field development is to be schieved at the Geysers.
\end{abstract}

\section{Introduction}

Ceothermal energy, although not benign, is a desirable ilternative to dependency upon other finite and relatively more environmentally harmful power generation cycles. It is the "preferred" source of the CEC for the generation of electric power but $\mathrm{H}_{2} \mathrm{~S}$ emissions have caused air quality problems:

The Geysers Known Geothermel Resource Area (KGRA) has been estimated by the Jet Propulsion Laboratories to have full field potential electric generation capacity of approximately 6200 mi. To date 502 mW (11) Doits) of generation capacity has been installed by Pacific Gas and Electric Company (PGE) and planned expansion has been slowed by $\mathrm{H}_{2} \mathrm{~s}$ problems.

Hydrogen sulfide is noncondensible gas, usually associated with geotherwal steam, which has a distinct, powerful odor affecting humans at levels of approximately .02 or .03 ppm (the latter figure being the Californis Ambient Air Quality Standard). Loss of the sense of swell can occur at about .06 ppm with eye irritation and fatigue resulting at $\mathrm{H}_{2} \mathrm{~S}$ levels of $.06-.07$ ppo. Respiratory irritation. from $\mathrm{H}_{2} \mathrm{~S}$ begins after one hour of exposure to levels of 100-200 ppo and deach occurs at 600-900 ppm.
Emissions and Air Quality Impacts

Measurements of the net $H_{a} S$ emission from the 11 units at the Geysers hâve been made by the North Sonome County Air Pollution Control District (APCD). In September 1977, total of $1174 \mathrm{lb} / \mathrm{hr}$ of $\mathrm{H}_{2} \mathrm{~s}$ was emitced by the pover plants. The use of is abatement equipwent, which had only been retrofit on three units et the time the measurements were taken, has proven undependable. These iroa catalyst $\mathrm{H}_{2} \mathrm{~S}$ control systems have been only 40 to 70 percent effective at reducing $H_{2} s$ emissions at full scale operation.

Calculations and estinates of H $\mathrm{S}$ emissions from other geothermal developoental activities were also made and nonpower plant sources of H $s$ (including, well drilling, testing, weli bfeeds, a currently uncontrolled well, pipeline vents and natural fumerals) were extinated to emic $63 \mathrm{lbs} / \mathrm{hr}$. Currently, about $1237 \mathrm{lb} / \mathrm{hr}$ H $s$ is emitted to the atmosphere from geothermal development at the Geysers.

The meterological and topographical conditions of the Geysers region are such that it is extremely difficult to directly correlate $\mathrm{H}_{2} \mathrm{~S}$ emissions from the power plant and air qualify impacts. The general pattern has been for H S enissions released at the Geysers in Sonoma County to be transported to and affect the populated areas of Lake County a few miles downwind to the east.

Prevailing meteorological conditions combined with the complexity of the local mountainous terrain result in violations of the California ambient air quality standard for $\mathrm{H}_{2} \mathrm{~s} \quad(.03$ PPm) in lake County. During the one-year period from October 1976 to September 1977 hourly average hydrogen sulfide levels equal to or in excess of .03 ppm were measured 1092 times by the eight station ait quality monitoring network maintained in the ares by Stanford Research Institute. The California Air Resources Board (ARB) estimates that it is necessary to reduce $H_{2} s$ emissions by factor of three (to about $391^{2} \mathrm{ib} / \mathrm{hr}$ ) for attainment of the air quality standard. 


\section{The Legal Framework}

The Karren-Alquist Act of 1974 (AB 1575) placed the ultimate permitting responsibility. for thermal power plants in California with the CEC. This means that future geothermal power plants (beginning with Unit 17) will 80 through the CEC Notice of Intent/Application for Certification (NOI/AFC) screening process.

The stated Commission policy is to consider geothermal ss a "preferred" source for meeting electricity supply. Policy and guidance, intended to maximize the use of geothermal resources, and to support the rapid expansion of geothermal power production is being implemented. Only site specific and environmental issues will demand resolution in the siting process due to newly adopted Commission policy. Through interagency action (CEC, ARB, North Sonoma County APCD and Lake County APCD) it is anticipated that existing and future $H_{2} s$ air quality problems, as well as the legal requirements and needs of each agency, can be satisfied in the commission's comron regulatory form.

The ARB in response to the Federal clean Air Act has drafted "model" New Source Review (NSR). regulations and requires that all APCD's in California adopt similar regulations. These regulations ensure that new at ationary source for which an air quality perwit is issued shall not prevent or interfere with the attainment or maintenance of any appliable air quality standard. Both national and state air quality. standards are required to be considered by the ARB guidelines. Lake and North Sonoma County $A P C D$ 's have adopted an NSR regulation in response to the guidelines established by ARB.

Both the ARB and the North Sonoma County APCD are presently proposing regulations to further restrict $H_{2} S$ emissions from existing and future geothermal development. In proposed amendments the North Sonoma County APCD regulations would require that existing geothermal power plant units emit no more than $350 \mathrm{lb} / \mathrm{hr}$ or $290 \mathrm{lb} / \mathrm{hr}$ of hydrogen sulfide (to be determined by the district). Also, any unit constructed after January 1, 1978, shall emit no more than: (a) three percent of the H, 5 produced by that units steam; or (b) 0.1 if. $\mathrm{H} \mathrm{s} / \mathrm{hr} / \mathrm{MW}$ to the atmosphere; or (c) $10 \mathrm{lbs} / \mathrm{hr}$ to the atmosphere; or (d) a level which is feasible by the use of best available control technology (BACT). The proposed North Sonoma County APCD regulations will also place restrictions on non-power plant sources of $\mathrm{H}_{2} \mathrm{~S}$.

ARB has held public workshops and has collected background information in order to draft model air pollution rggulations for $\mathrm{H}_{2} \mathrm{~S}$ from geothermal operations. The ARB staf ${ }^{2}$ report
Table 1 ARB PROPOSED MODEL RULE ON $\mathrm{H}_{2} \mathrm{~S}^{*}$ CONTROL STRATEGY

\begin{tabular}{ll} 
CONDITIONS & $\begin{array}{c}\text { APPROXIMATE } \\
\text { DEGREE OF } \\
\text { CONTROL }\end{array}$ \\
\hline
\end{tabular}

1979 1. Pover plant units numbèr $3,4,5,6,11$, and 12 to emit no wore than 200

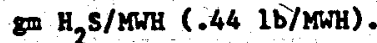

2. Power plant units equipped with surface condensers to emit no more than $175 \mathrm{gm}$ $\mathrm{H}_{2} \mathrm{~s} / \mathrm{MWH}(.39 \mathrm{lb} / \mathrm{MWH})$.

1980 1. Power plant units equipped with surface condensers to emit no wore than $100 \mathrm{gm}$ $\mathrm{H}_{2}$ S/MWH $(.22$ 1b/MWH).

2. All power plant units constructed or commencing construction during 1980 shall emit no more than $100 \mathrm{gm}$ $\mathrm{H}_{2} \mathrm{~S} / \mathrm{MWh}(.22 \mathrm{lb} / \mathrm{MWH})$ when cómpleted.

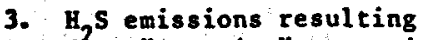
from "stacking" operations shall be reduced by $65 \%$ (from levels associated with unabated steanflow) within 30 minutes.

4. H 5 emissions fo drilling 60-90 operations shall not exceed $5 \mathrm{~kg} / \mathrm{hr}(11 / 1 \mathrm{~b} \mathrm{hr})$ for every $1000 \mathrm{~kW}$ of electrical power generated.

1982 1. The uncontrolled geothermal, 90 well known as Thermal. 4 (or the "Wild Well") will have its $H_{2}$ S emissions reduced by $90 \%$ over its abated conditions.

1984 1. All power plant units uti- 90 lizing direct contact condensers will emit no more than $200 \mathrm{gm} \mathrm{H}$ S/ MWH $(.44 \mathrm{lb} / \mathrm{MWH})$.

1986 1. H $S$ emisions resulting from "stacking" operations shall be reduced by $90 \%$ (from levels associated with unabated steam flow) within 30 minutes.

2. All power plant units completed after 1985 shall emit no more than $50 \mathrm{gm}$ $\mathrm{B}_{2} \mathrm{~S} / \mathrm{MWH}$ (.11 16/MWH).

1990 1. Al power plant units equipped with surface condensers shall emit no more than $50 \mathrm{gm} \mathrm{H} / \mathrm{S} / \mathrm{MWH}(.11 \mathrm{lb} / \mathrm{MWH})$.

2000 1. Al power plant units equipped with direct contact condensers shall enit no more than $100 \mathrm{gm} \mathrm{H} / \mathrm{s} / \mathrm{MWH}$ (.22 lb) WHE).

«Adopted by ARB April 26, 1978. 
and recomendations are expected to be presented to the full board in April 1978. A cummary of the ARB proposed model rules to control $\mathrm{H}_{2} \mathrm{~S}$ is presented in Table 1 .

\section{Projected Growth}

In - effort to develop an integrated, statevide, electricity supply strategy the Energy Commission has required that all California utilities' provide planning documents prescribing the manner in wich each utility would meet future forecasted electricity demand for its service area. Table II lists all of the development currently being planned by electric utilities for the Geysers RGRA. Three urilities, Pacific Gas and Electric Company (PCEE), Sacramento Municipal Utilities District (SKUD) and Northern California Power Associstion (NCPA) indicate that $2708 \mathrm{KH}$ of electricity could be produced at the Geysers by 1990. The only other generation capacity now planned for the Geysers is $165 \mathrm{MW}$ by the California Department of Water Resources.

It should be noted that $\mathrm{B}_{2} \mathrm{~s}$ control efficiencies were not indicated for iron catalyst control systems on units 1-11. These systems are not presently on all of PG\&E's existing units, although it does sppear as though PG\&E expects to retrofit with iron catalyst and attain $\mathbf{9 0}$ percent abatement efficiency on these units.

The expected Geysers cumulative H $\mathrm{S}$ emissions utilizing various levels of control efficiency and ssuming developwent proceeds as planned, ere presented by year in the columns on the right in Table II. Expected cumulative emissions and the net relationship to current emissions levels at the Geysers is presented in Figure I. Although the utilities have indicated that up to 90 percent control of HS is expected, the ultimate degree to which $\mathrm{H}_{2} \mathrm{~s}$ wust be controlled at the Geysers has not yet been established. Since ambient air quality standards are currently being violated, logic would indicate that net future emissions over $1174 \mathrm{lb} / \mathrm{hr}$ would cause continuing violations. Even $95 \%$ control of $H_{2} S$ may not be sufficient if a reduction down to one third of current emission levels is required. Control efficiencies of 96-99 percent appear to be required if ultimate compliance with standards and full field development is desired.

The proposed ARB regulations (Table 1) call for 95 percent of 211 units completed after 1985. It is unclear at this time whether this degree of control can be technically achieved or is ultimately suficient to prevent violations of the ambient air quality standard for $\mathrm{H}_{2} \mathrm{~s}$.

\section{Ho Abatement Technologies}

A cubstantial amount-of money and time has been expended (primarily by PGEE) in efforts to control the releases of $\mathrm{H}_{2} \mathrm{~S}$ to the atmosphere by zeothermal operations. 2 Several different approaches to $\mathrm{H}, \mathrm{S}$ control have been investigated and the three most promising are: (1) Iron Catalyet; (2) Stretford; and (3) EIC Upstream. Information is provided in Table III regarding the $\mathrm{H}_{\mathrm{s}}$ abatement technologies currently being tested by PGE. By mid-1979 more precise operational charecteristics vill be available on all these systems.

of the systems under consideration, only the Iron Catalyst system has been in full-scale operation, with rather unsatisfactory results (40 to 70 percent efficiency). The stretford system is expected to provide high control efficiencies on new units using surface condensers (as opposed to direct contact condensers on units 1-12). The stretford system is presently unproven, hovever, because there is no operating experience to indicate the degree of $\mathrm{H}, \mathrm{s}$ partitioning which will occur in the surfice condenser. The EIC Upstream system is in the very early stages of development but spears to be promising. If successful it would enable removal of $\mathrm{H}_{2} \mathrm{~s}$ from the geothermal team resource before it enters the power plant.

FIGURE I: PROJECTED INCREASES IN H, $\mathrm{s}$ EMISSIONS FROM PLANNED POWER PLANT UNITS AT THE GEYSERS

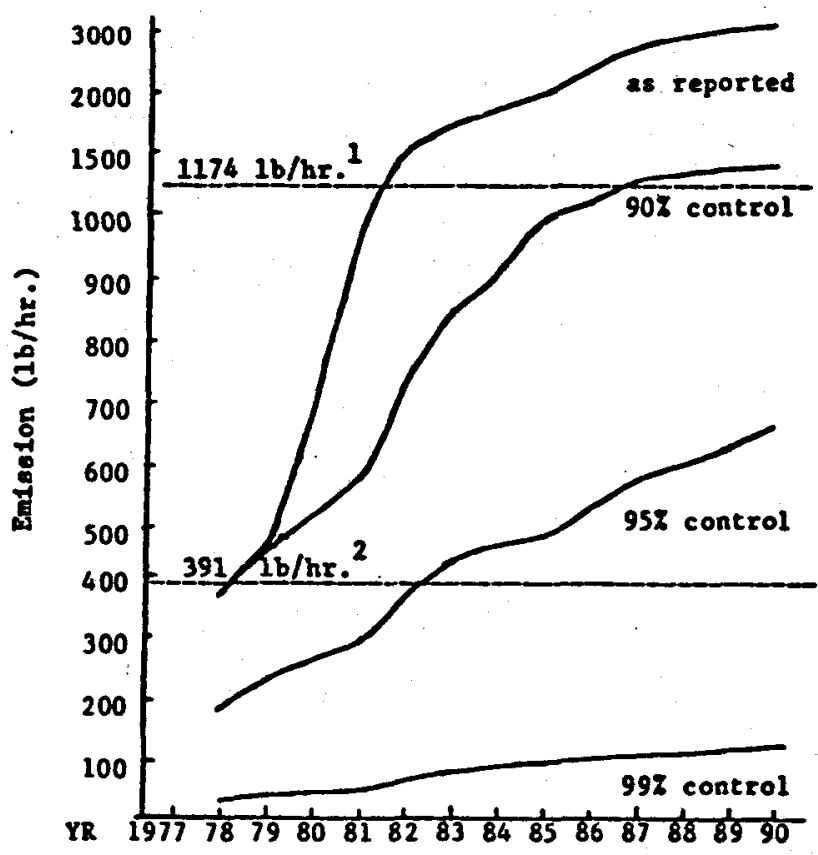

11977 Emission level.

2 ARB estimated roll back requirement.

Conclusion

The limit to which geotherwal development can occur at the Geysers presentiy seems to be restricted by two factors: (1) the ultimate size of the resource, (which has yet to be definitively eatablished); and (2) more immediately, by the failure to maintain the state ambient air quality standard for $\mathrm{H}_{2} \mathrm{~S}$. 
TABLE II

PROJECTED GEOTHETHAL POWER PRODUCTION AND $\mathrm{H}_{2} \mathrm{~S}$ EISSIONS IN THE GEYSERS RGRA

UNIT DATA

COMULATIVE TOTAL

CONTROLLED $\mathrm{h}_{2} \mathrm{~s}(\mathrm{lb} / \mathrm{hr})$

YEAR H,S DMMIS-

ON SIZE REAT RATE SION FACTOR, CONTROL,
UNIT * LINE (MW) (BTU/KWH) (LBS/BTUX106) DEVICE

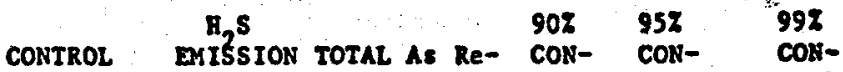

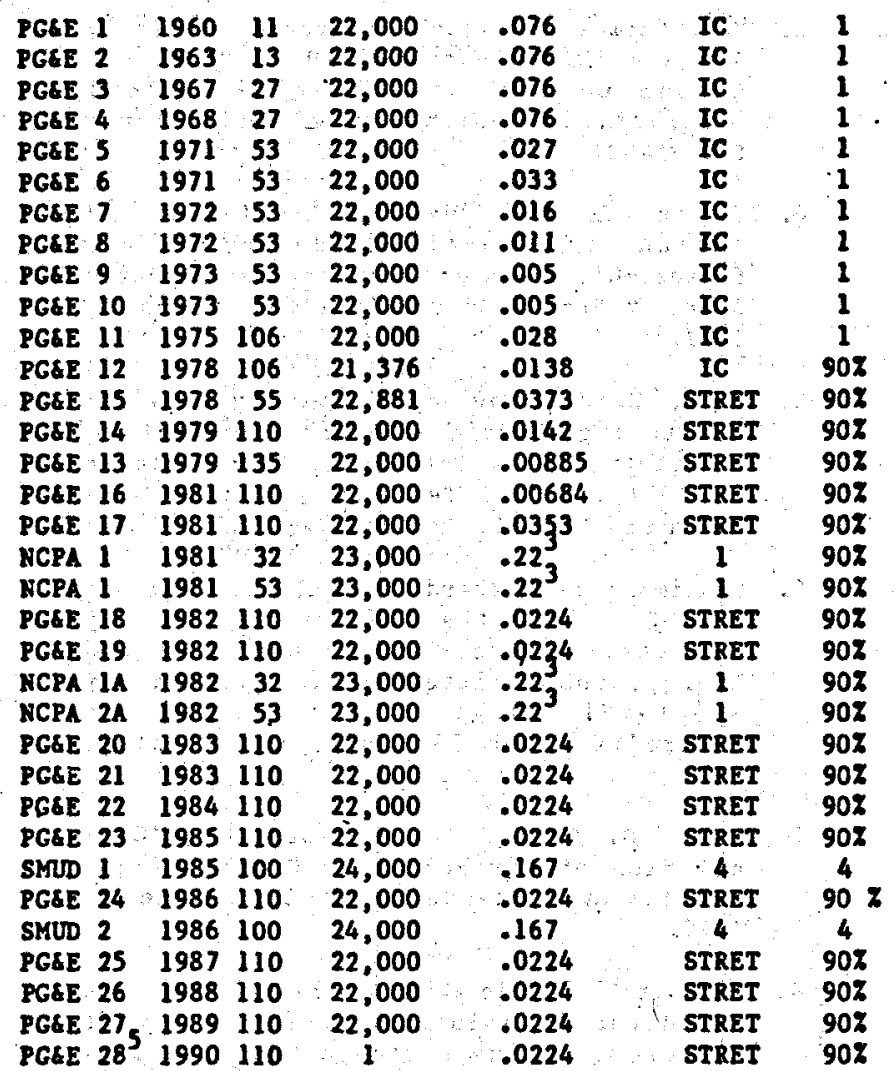

18.3

21.7

45.1

45.1

31.5

38.5

18.7

12.8

5.8

5.8

65.3

31.3

46.9

34.6

26.3

$16: 6$

502

$\begin{array}{lllll}663 & 386.8 & 386.8 & 193.4 & 38.7\end{array}$

$\begin{array}{llllll}908 & 447.7 & 447.7 & 233.9 & 44.8\end{array}$

85.4

161.9

268.2

54.2

$\begin{array}{llllll}1213 & 979.8 & 592.7 & 296.4 & 59.3\end{array}$

54.2

161.9

268.2

54.2

54.2

54.2

34.2

400.8

54.2

400.8

$54.2,23782645$

$\begin{array}{lllllll}54.2 & 2488 & 2699.3 & 1203.8 & 601.5 & 120.4\end{array}$

$\begin{array}{llllllll}54.2 & 2598 & 2753.5 & 1258.0 & 629.0 & 125.8\end{array}$

PGGE 28 1990 110

34.2

$1518 \quad 1518.3 \quad 744.2 \quad 372.1 \quad 74.4$

$\begin{array}{lllllll}1738 & 1626.7 & 852.6 & 426.3 & 85.3\end{array}$ $\begin{array}{llllll}1848 & 1680.9 & 906.8 & 453.4 & 90.7\end{array}$

$2058 \quad 2135.9 \quad 1001.1 \quad 500.6 \quad 100.1$

$\begin{array}{llllll}2708 & 2807.7 & 1312.2 & 656.1 & 131.2\end{array}$

\footnotetext{
1. Inforwation not provided by utilities.

2. Control Devices: IC= Iron Catalyst, STRET = Stretford Process.

3. The NCPA Emission Factor appears to be representative of an uncontrolled sace.

4. SMUD did not indicate any control.

5. The location of Unit 28 was not given, it may or may not be in the Geysers KGRA.
} 
TABLE III

Hydrogen Sulfide Abatement Technologies

\begin{tabular}{|c|c|c|c|}
\hline & Iron Catalyst & Stretford & $\begin{array}{c}\text { EIC } \\
\text { Upstream }\end{array}$ \\
\hline $\begin{array}{l}\text { Abatement } \\
\text { Efficiency }\end{array}$ & $\begin{array}{l}\text { Actual } 40-70 z \\
\text { Potential } 907\end{array}$ & $\begin{array}{l}80-987 \\
90+7 \text { from } \\
\text { Condensate }\end{array}$ & $90-977$ \\
\hline $\begin{array}{l}\text { Expected } \\
\text { Downtime }\end{array}$ & $10 z$ & 58 & $5 \%$ \\
\hline $\begin{array}{l}\text { Estimated } \\
\text { Capital } \\
\text { Cost }\end{array}$ & $\$ 3$ million & $\begin{array}{l}\$ 5.84-6.7 \\
\text { million }\end{array}$ & $\begin{array}{l}\text { Similar } \\
\text { to } \\
\text { StRET. }\end{array}$ \\
\hline $\begin{array}{l}\text { Estimated } \\
\text { Annual cost }\end{array}$ & $\$ 995,000$ & $\begin{array}{l}\$ 1,350,000 \\
\$ 2,275,000 \\
\text { with Con- } \\
\text { densate } \\
\text { Treatment }\end{array}$ & $\$ 1,245,00$ \\
\hline $\begin{array}{l}\text { Expected } \\
\text { Avail- } \\
\text { ability }\end{array}$ & $\begin{array}{l}90 \% \text { Abatement } \\
\text { Full scale } \\
\text { end of } 1978\end{array}$ & $\begin{array}{l}\text { Fullscale } \\
\text { on Unit } 15 \\
\text { Early } 1979\end{array}$ & $\begin{array}{l}\text { Pilot } \\
\text { July } 1979 \\
\text { Fullscale } \\
\text { Mid-1982 }\end{array}$ \\
\hline
\end{tabular}

If it cannot be demonstrated that geothermal power plants can operate without causing violations of the $.03 \mathrm{ppm}$ hydrogen sulfide standard and comply with proposed hydrogen sulfide regulations of the ARB and local APCD's, it would be imprudent to expect unrestricted development at the Geysers. No agency has yet established precisely what level of $\mathrm{H}_{2} \mathrm{~S}$ control (or emissions) will be required tô allow full field development. Al though most proposed regulation is presently in the range of 90-95 percent control, more stringent controls may be necessary if thousands of megawatts of electricity are to be produced at the Geysers.

Achieving the goal of full field development remains hypothetical. Uncertainties presently associated with development of geothermal $\mathrm{H}_{2} \mathrm{~S}$ control technologies are numerous. It 18 possible that a level of $\mathrm{H}_{2} \mathrm{~S}$ control sufficient to eliminate $\mathrm{H}_{2} \mathrm{~S}$ as an environmental problem may not be available soon. Should adequate $n_{2}$ s control prove unavailable planned geothermal development at the Geysers may be seriously hindered and eventually curtailed. Every effort should be made to ensure against such an eventuality. This analysis is intended to communicate the status of an eminent regulatory problem and encourage expanded research and planning to resolve the issue.

The views and conclusions contained in this report are those of the authors and should not be interpreted as necessarily representing the official policies of either the California Energy Comission or the State of California.
REFERENCES

JOYCE/FONTES

1. Lefkowitz L. P.: "The Impact of $\mathrm{H}_{2} \mathrm{~S}$. on Future Geothermal Power Generation: ${ }^{2}$. The Geysers Region, California," Jet Propulsion Laboratory, Pasadena, Ca 91103.

2. Robertson, Dave: "Paper presented at Lawrence Livermore Laboratories Workshop, October 1977" Battelle Pacific Northwest Laboratories.

3. "Geothermal Air Quality Progress Report, January 1976--September 1977," Northern Sonoma County Air Pollution Control District, 141 Ṇorth Street, healdsburg, CA. 95448 .

4. Joyce, Larry, "Hydrogen Sulfide and Ambient Air Quality Modeling in the Geysers-Calistoga known Geothermal Resource Area, A Status Report," CERCDC, March 2, 1977.

5. Ruff, R. E., Cavanagh, L.A. "Specialized Monitoring Services Quarterly Reports covering periods October 1, 1976--October 1. 1977 Stanford Research Institute, 333 Ravenwood Avenue, Menlo Park, CA. 94025.

6. Testimony of Richard L. Maullin, Chairman CERCDC before the California Assembly Committee on Reso:=ces, Land Use and Energy, Subcomittee on Energy, "Energy Supply Planning: Strategies for the Future" October 19, 1977, Los Angeles, CA.

7. Palo, G. Peter, A. and Woo, D. "Compilation at Air Pollution Control Regulations and Standards CERCDC, June 8, 1976.

8. Exhibit "A" Rule 455 Geothermal Emission Standards "Resolution of the Board of Directors of the Northern Sonoma County Air Pollution Control District Amending the Rules and Regulations for said District.

9. "Proceedings: Air Resource Board Workshop on Air Pollution Regulations for Hydrogen Sulfide from Geothermal Operations, Santa Rosa, CA. February 17, 1978.

10. "Utility Supply Plans" in response to CERCDC Order Securing Information No. 77-622-14.

11. Weinburg, Carl "Pacific Gas and Electric Company, The Geysers Power Plant H, Abatement Research and Development" February 17, 1978. 